Barbara Regina Bouças Pontes

\title{
Preparação e Caracterização de Termoplásticos a partir de Amido de Arroz
}

Dissertação de apresentada ao Instituto de Química de São Carlos, da Universidade de São Paulo para obtenção do título de Mestre em Ciências.

Área de concentração: Físico-Química

Orientador: Prof. Dr. Antonio Aprigio da Silva Curvelo

São Carlos

2012 


\section{Dedicatória}

Ao Arã Cunha, meu

companheiro de vida e de luta. 


\section{AGRADECIMENTOS}

À minha família e amigos.

Ao Prof ${ }^{\circ}$. Aprigio pela oportunidade, incentivo e confiança.

Aos amigos do grupo de Físico-Química Orgânica.

Ao Instituto de Química da USP de São Carlos (IQSC) pela infra-estrutura e técnicos de apoio.

Ao Instituto de Física de São Carlos, em especial à Dra. Débora Baloghi pelo uso do DMTA.

Ao Prof ${ }^{\circ}$. Dr. José Ricardo Tarpani da Escola de Engenharia de São Carlos pelos ensaios mecânicos, em especial aos alunos e técnicos do Departamento de Engenharia de Materiais da EESC.

À Prof ${ }^{\mathrm{a}}$. Dra. Nicole Raymonde Demarquette do Departamento de Engenharia de Metalurgia e de Materiais da Escola Politécnica da USP pelo uso do reômetro de torque, principalmente ao Técnico Kleber Vaccioli.

À EMBRAPA, em especial à Eliângela Teixeira pelo uso do reômetro de torque.

Ao CNPQ pela bolsa concedida. 


\section{RESUMO}

O presente trabalho teve como proposta a preparação de amidos termoplásticos (TPS) e compósitos a partir de amido de arroz e subprodutos do processo de beneficiamento do arroz, no qual resulta em $20 \%$ de palha e $14 \%$ de grãos quebrados. Estudou-se o amido de arroz como nova fonte para preparação de termoplásticos, avaliou-se o efeito da incorporação de palha de arroz aos TPS a fim de superar as limitações apresentadas por estes tais como baixo desempenho mecânico e alta absorção de umidade, avaliou-se a possibilidade de preparação de termoplásticos diretamente dos grãos de arroz e quirera e investigou-se a influência das condições de processamento (tempo e temperatura) na preparação dos termoplásticos. $\mathrm{O}$ amido de arroz foi plasticizado com glicerol em proporções que variaram de 20 a $40 \%$. Para os compósitos, o teor de reforço (palha) variou de 1 a $5 \%$ e o teor de glicerol foi fixado em $30 \%$. Tanto os materiais de partida quanto os termoplásticos e compósitos obtidos foram caracterizados por MEV e difração de raios-X; quanto às propriedades térmicas por TG, DSC e DMTA; quanto às propriedades mecânicas por ensaio mecânico de tração. $O$ comportamento frente à absorção de água também foi investigado. O estudo das condições de processamento foi feito com base nos resultados obtidos a partir da reometria de torque, difração de raios-X e MEV e demonstrou que a utilização de apenas uma das técnicas é insuficiente para determinação das condições de processamento que melhor contribuem para desestruturação do grânulo, mistura e homogeneização do TPS. Os TPS preparados a partir de amido de arroz e glicerol seguiram a mesma tendência de variação de suas propriedades em função do teor de plasticizante que os TPS preparados a partir de outras fontes de amido. Levando em consideração TPS preparados a partir de amido de mandioca, milho e batata, observa-se que os TPS preparados a partir de amido de arroz apresentaram a menor absorção de água. Em relação aos compósitos, a palha contribuiu para melhorar o desempenho mecânico, no entanto favoreceu o aumento da absorção de água. Foi possível obter termoplásticos preparados diretamente dos grãos de arroz (polido e integral) e da quirera. Em comparação com o TPS amido/glicerol, os TPS obtidos a partir dos grãos apresentaram maior cristalinidade, rigidez e temperatura de transição vítrea. No entanto, apresentaram menor estabilidade térmica, menor ductilidade e maior absorção de água. 


\begin{abstract}
This work aimed at preparation of thermoplastic starch (TPS) and composites from rice starch and byproducts of the beneficiation process of rice, which results in $20 \%$ of husk and $14 \%$ of broken grains. The rice starch was studied as a new source for preparing thermoplastics. The effect of incorporation of rice husk to the TPS was evaluated aiming to overcome the limitations presented by pure TPS such as poor mechanical properties and high moisture absorption. The preparation of thermoplastic directly from grain and broken rice was also studied. The rice starch was plasticized with glycerol in proportions ranging from 20 to $40 \%$. For composites, the amount of husk ranged from 1 to $5 \%$ and glycerol content was $30 \%$. The effect of processing conditions (time and temperature) in the preparation of thermoplastics were investigated. Starting materials, thermoplastics and composites were characterized by SEM and X-ray diffraction; the thermal properties by TG, DSC and DMTA; and mechanical properties by mechanical tests. The behavior in the water uptake was also investigated. The processing conditions study was based on the results obtained from the torque rheometry, X-ray diffraction and scanning electron microscopy and demonstrated that the use of only one technique is inadequate to determine the best processing conditions. The TPS prepared from rice starch and glycerol followed the same trend of variation of its properties as a function of plasticizer content when compared to TPS prepared from other starch sources. Considering TPS prepared from cassava starch, corn and potato, it was observed that the TPS prepared from rice starch presented a lower water uptake. For composites, husk has improved mechanical performance, but favors the increase in water uptake. It was possible to obtain thermoplastic prepared directly from grain rice (polished and integral) and broken grain. Compared to the starch/glycerol TPS, TPS obtained from the grains had higher crystallinity, and stiffness and glass transition temperature. However, had lower thermal stability, lower ductility and increased absorption of water.
\end{abstract}




\section{LISTA DE FIGURAS}

Figura 1.1.1 - Estrutura química da amilose (a) e da amilopectina (b). 16

Figura 1.1.2 - Modelo de clusters proposto para a molécula de amilopectina (adaptado de COULTATE, 2002): (a) Modelo de cluster; (b) Organização das regiões amorfas e cristalinas; (c) orientação das moléculas de amilopectina numa seção do grânulo e (d) Formação de estruturas tipo hélice dupla relacionadas com o grau de cristalinidade no grânulo

Figura 1.2.1 - (A) Planta do arroz, (B) grão de arroz com casca (GUIMARÃES; FAGERIA; FILHO, 2002). 21

Figura 1.2.2 - Esquema ilustrativo do processo de beneficiamento do arroz. .22

Figura 1.2.3 - Estrutura interna da casca de arroz: a) tricoma, b) epiderme superior, c) esclerênquima, d) parênquima, e) epiderme inferior, f) feixe vascular, g) estômato, h) vest[igio de pequeno tricoma (SILVA, 1997). 24

Figura 3.1.1 - Exemplo para determinação do índice de cristalinidade. 32

Figura 4.1.1 - Micrografia de MEV para o amido de arroz com aumento de 4000 vezes

Figura 4.1.2 - Micrografias de MEV com aumento de 500x para palha I, superfícies inferior (A) e superior (B); e para palha $C$, superfícies inferior (C) e superior (D).

Figura 4.1.3 - Micrografias de MEV para palha M: (A) aumento de 250x; (B) superfície superior, aumento de 500x; (C) superfície inferior, aumento de $500 x$

Figura 4.1.4 - Micrografias de MEV para palha $P$ : (A) superfície superior, aumento de 250x; (B) superfície inferior, aumento de 500x; (C) fibras, aumento de 500x; (D) fibras, aumento de $1000 \mathrm{x}$.

Figura 4.1.5 - Difratogramas de raios-X para o amido, grão e palha de arroz (A) e a ampliação do sinal para o amido e grão de arroz (B).

Figura 4.1.6 - Curvas TG e DTG para o amido, quirera, grão integral e palha de arroz.

Figura 4.1.7 - Curvas DSC para determinação do teor de amilose do amido de arroz. 45

Figura 4.1.8 - Cromatograma de HPSEC para amido de arroz.. .46

Figura 4.2.1 - Curva obtida em um reômetro de torque.. 
Figura 4.2.2 - Curvas de torque versus tempo para processamento com tempo máximo fixado em 8 minutos e com variação de temperatura

Figura 4.2.3 - Curvas de torque versus tempo para amostras processadas em temperatura fixada em 120 oC e com variação do tempo máximo de processamento. .50

Figura 4.2.4 - Perfil cristalográfico das amostras processadas $(A)$ em tempo máximo fixado em 8 minutos, (B) em temperatura de processamento fixada em $120^{\circ} \mathrm{C}$ .51

Figura 4.2.5 - Índice de cristalinidade do tipo V para amostras processadas em tempo máximo de 8 minutos, com variação da temperatura $(A)$; com temperatura fixada em 120 oC, com variação do tempo máximo de processamento $(B)$. .52

Figura 4.2.6 - Micrografias de MEV para amostras processadas em tempo máximo de 8 minutos e temperatura em (A) 100 oC, (B) 110 oC, (C) 120 oC, (D) 130 oC e (E) 140 oC; com aumento de 500x.

Figura 4.2.7 - Micrografias de MEV para amostras processadas em temperatura fixada em 120 oC e com variação de tempo em (A) $4 \mathrm{~min},(B) 6 \mathrm{~min},(C) 8 \mathrm{~min}$, (D) 10 e (E) 12; com aumento de 500x. .54

Figura 4.2.8 - Cromatogramas de HPSEC para amostras processadas com tempo máximo fixado em 8 minutos e com variação de tempo $(A)$ e com temperatura fixada em 120 oC e com variação de tempo máximo (B). .55

Figura 4.3.1 - Micrografias de MEV para os TPS com 20\% (A), 25\% (B), 30\% (C), $35 \%$ (D) e 40\% (E) de plasticizante .....................................................58

Figura 4.3.2 - Difratograma de raios-X dos TPS amido/glicerol............................59

Figura 4.3.3 - Índice de cristalinidade dos TPS amido/glicerol: tipo Vh (A) e tipo B (B). .59

Figura 4.3.4 - Curvas de absorção de água (\%) em função do tempo (h) para amostras de TPS condicionadas em ambientes de umidade relativa de $22,5 \%$ (A), 43\%(B), 53\% (C), 75\% (D) e 84\%.

Figura 4.3.5 - Absorção máxima de água em função do teor de glicerol para os TPS de amido de arroz.

Figura 4.3.6 - Curvas de tensão $X$ alongamento para os TPS de amido de arroz plasticizados com diversos teores de glicerol. 
Figura 4.3.7 - Comportamento mecânico de tensão máxima na ruptura (A),

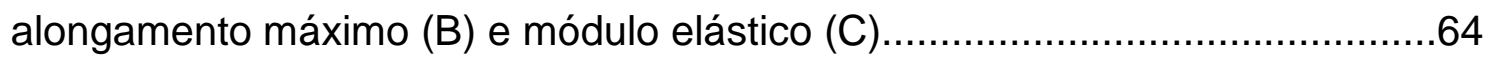

Figura 4.3.8 - Curvas TG e DTG para TPS de amido/glicerol.................................65

Figura 4.3.9 - Curvas de DSC para amostras de TPS amido/glicerol: (A) curva

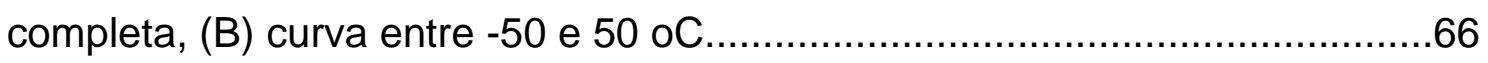

Figura 4.3.10 - Curvas da tangente de perda (tan $\square$ ) (A) e módulo de armazenamento (E') (B) em função da temperatura para os TPS amido/glicerol.

Figura 4.4.1 - Curvas de absorção de água em função do tempo para amostras de compósitos de palha C condicionadas em ambiente controlado de 53\% u.r .70

Figura 4.4.2 - Absorção máxima de água para os compósitos condicionados em ambiente de u.r. $53 \%$ em função do teor de palha e forma de incorporação. .71

Figura 4.4.3 - Curvas de tensão $\mathrm{x}$ deformação para compósitos amido de arroz/glicerol/palha. (A) Palha I, (B) Palha C, (C) Palha M e (D) Palha P.........72

Figura 4.4.4 - Tensão máxima (A), alongamento máximo (B) e módulo elástico (C) para compósitos amido de arroz/glicerol/palha...............................................

Figura 4.4.5 - Micrografias com aumento de 100x para os compósitos com $4 \%$ de palha e aumento de 250\% para TPS amido/glicerol.........................................75

Figura 4.4.6 - Micrografias de MEV com aumento de 1000x para compósitos com as diversas formas de incorporação de palha. .76

Figura 4.4.7 - Difratogramas de raios-X obtidos para os compósitos com palha P. . .77

Figura 4.4.8 - Índices de cristalinidade do tipo Vh (A) e B (B) para os compósitos

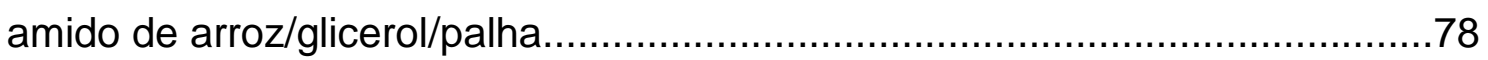

Figura 4.4.9 - Curvas TG e DTG para compósitos com palha $M(A)$, palha $P(B)$, palha I (C) e palha $C(D)$ .79

Figura 4.4.10 - Tangente de perda ( $\tan \delta$ ) e módulo de armazenamento (log E') para compósitos de palha I e palha $\mathrm{M}$.

Figura 4.5.1 - Micrografias de MEV com aumento de 500x para TPS preparados a partir de grãos de arroz, quirera e TPS amido/glicerol...... 84

Figura 4.5.2 - Foto (A) TPS polido; (B) TPS quirera, (C) TPS integral. .84 
Figura 4.5.3 - Difratogramas de raios-X dos TPS polido, TPS integral, TPS quirera

Figura 4.5.4 - Índices de cristalinidade do tipo Vh (A) e B (B) para amostras TPS quirera, TPS integral e TPS polido

Figura 4.5.5 - Curvas de tensão $x$ deformação para TPS integral, TPS quirera e TPS polido

Figura 4.5.6 - Tensão máxima (A), alongamento máximo (B) e módulo elástico (C) para TPS polido, TPS quirera e TPS integral.

Figura 4.5.7 - Curvas da absorção de água em função do tempo (A) e absorção máxima de água para TPS integral, TPS quirera e TPS polido condicionados em ambiente de u.r. $=53 \%$ .89

Figura 4.5.8 - Curvas TG e DTG para os TPS polido, TPS quirera e TPS integral .90

Figura 4.5.9 - Curvas de tan $\square$ (A) e log E' (B) em função da temperatura para TPS polido, TPS integral e TPS quirera. 


\section{LISTA DE TABELAS}

Tabela 1.1.1 - Características de amidos de diferentes origens botânicas...............19

Tabela 1.2.1 - Composição química (\%) do arroz integral, polido e quirera..............23

Tabela 3.1.1 - Programação de temperatura para determinação do teor de amilose

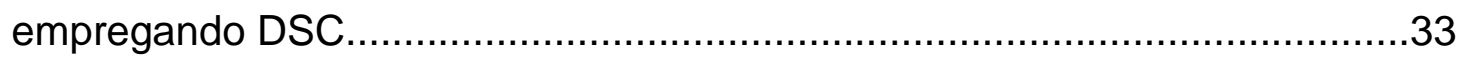

Tabela 4.1.1 - Teores de umidade dos materiais de partida.................................44

Tabela 4.3.1 - Tg em função do teor de glicerol para TPS amido/glicerol................67

Tabela 4.4.1 - Temperatura de transição vítrea para compósitos de palha de

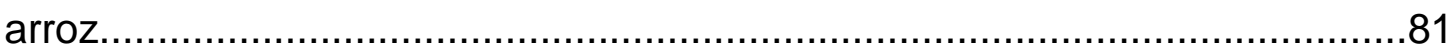




\section{LISTA DE ABREVIATURAS E SIGLAS}

TPS - Amido termoplástico.

$\mathrm{V}_{\mathrm{a}}$ - Cristalinidade do tipo- $\mathrm{V}$, anidro

$\mathrm{V}_{\mathrm{h}}$ - Cristalinidade do tipo- $\mathrm{V}$, hidratado

MEV - Microscopia eletrônica de varredura

Ic - índice de cristalinidade

$\mathrm{Ha}$ - Altura correspondente à fase amorfa do difratograma

$\mathrm{Hc}$ - Altura correspondente ao pico cristalino do difratograma

TG - Termogravimetria

LPC - Enzima L- $\alpha$-lisofosfatidilcolina

DSC - Calorimetria Exploratória Diferencial

$\mathrm{NaNO}_{3}$ - Nitrato de Sódio

$\mathrm{NaOH}$ - Hidróxido de Sódio

HPSEC - Cromatografia por Exclusão de Tamanho de Alta Eficiência

DTG - Derivada de Análise Termogravimétrica

$\Delta \mathrm{H}_{\text {amostra }}$ - Entalpia da amostra

$\Delta \mathrm{H}_{\text {padrão }}$ - Entalpia padrão

u.r.- Umidade Relativa

Tm - Temperatura de Fusão

Tg - Temperatura de Transição Vítrea

DMTA - Análise Térmica-Dinâmico-Mecânica

$\tan \delta$ - Tangente de perda

E' - Módulo de armazenamento ou módulo elástico 


\section{SUMÁRIO}

1 INTRODUÇÃO

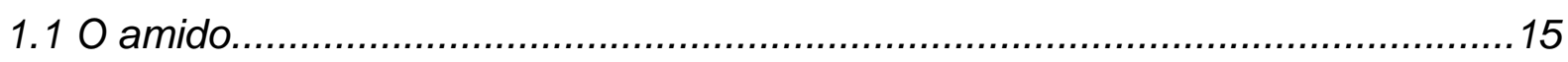

1.20 arroz

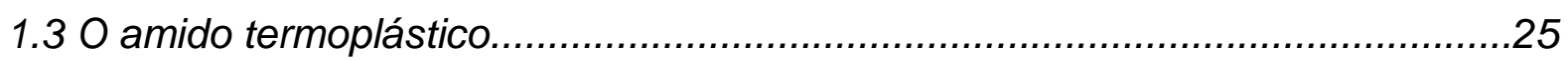

2 OBJETIVOS

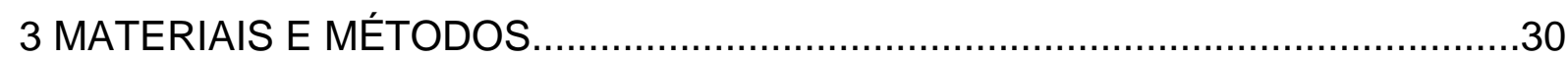

3.1 Preparação e caracterização dos materiais de partida: quirera, amido,

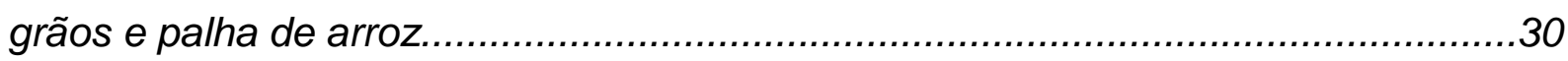

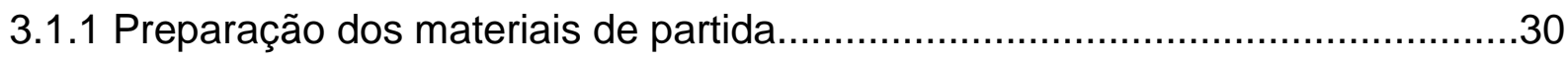

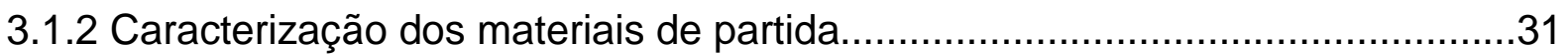

3.1.2.1 Microscopia eletrônica de varredura (MEV) .............................................

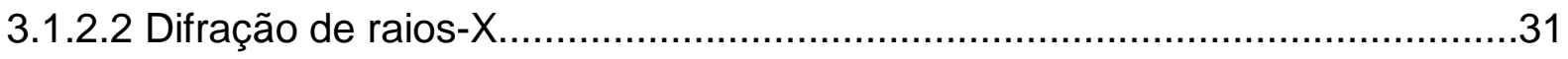

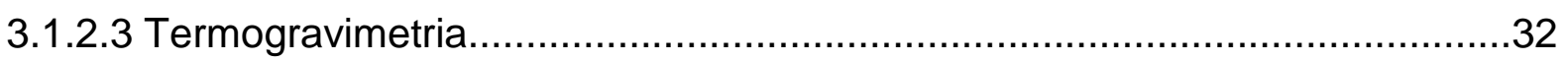

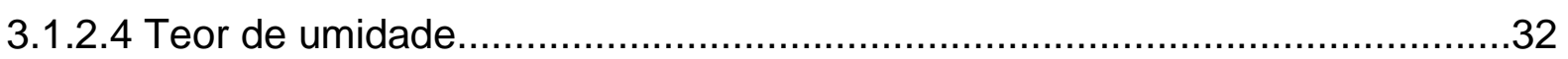

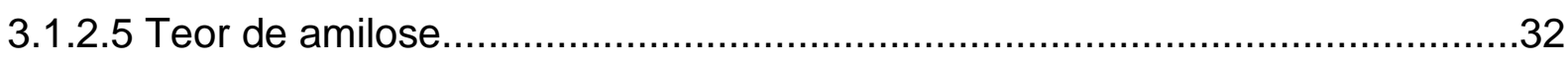

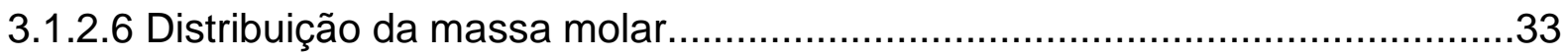

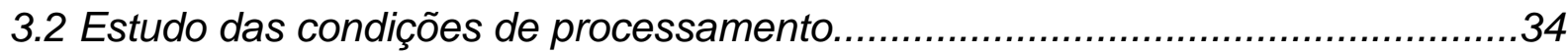

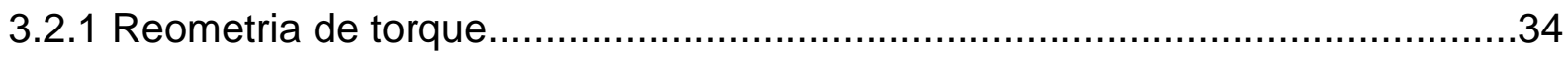

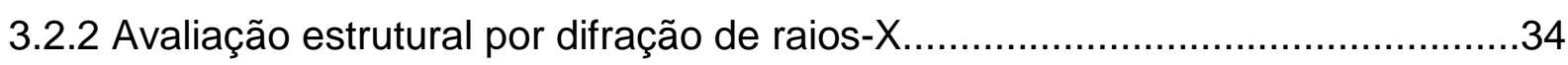

3.2.3 Análise da morfologia por Microscopia eletrônica de varredura (MEV)............35

3.2.4 Estudo do efeito das condições de processamento na degradação do

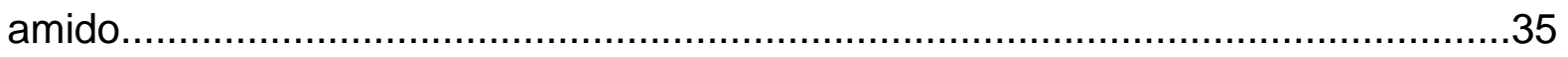

3.3 Preparação e caracterização dos termoplásticos e compósitos...........................35

3.3.1 Preparação dos termoplásticos e compósitos................................................35

3.3.2 Caracterização dos termoplásticos e compósitos obtidos..................................36

3.3.2.1 Estudo morfológico e estrutural..............................................................

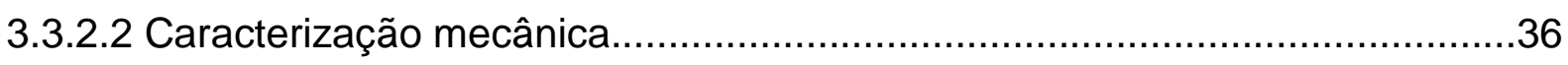

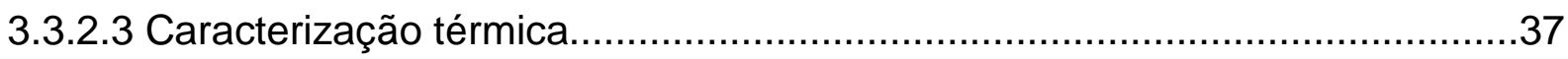


3.3.2.4 Avaliação da capacidade de absorção de água..........................................37

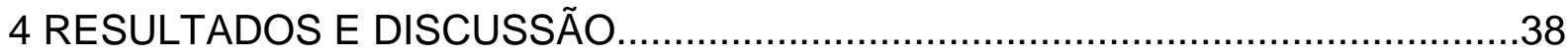

4.1 Caracterização dos materiais de partida: amido, palha e grãos de arroz.............38

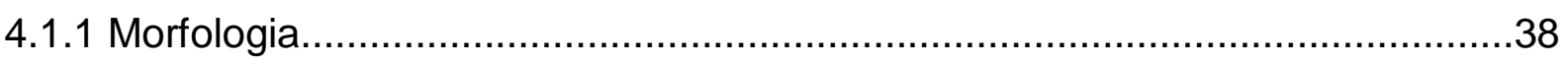

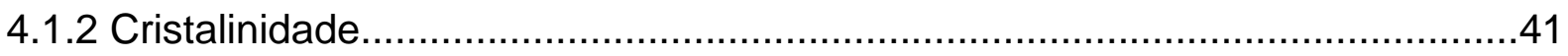

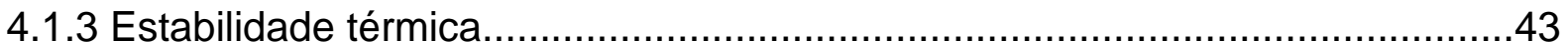

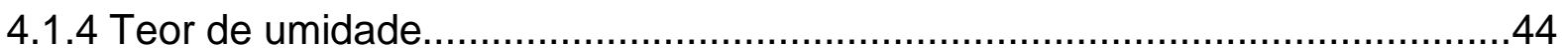

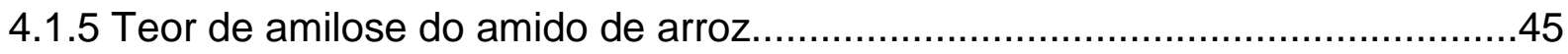

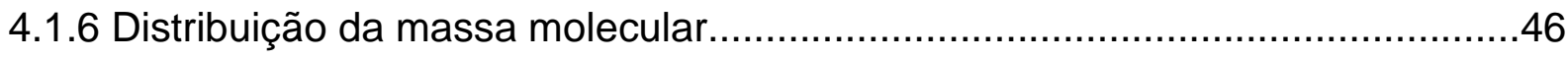

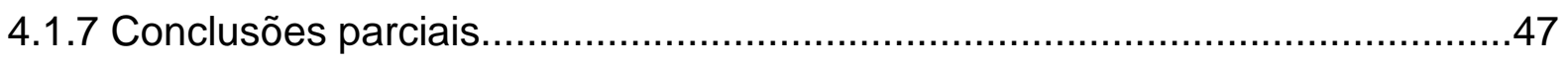

4.2 Estudo das condições de processamento.....................................................

4.2.1 Avaliação dos materiais a partir da reometria de torque................................48

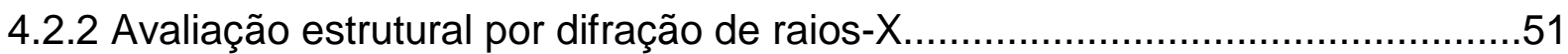

4.2.3 Análise da morfologia por Microscopia Eletrônica de Varredura (MEV)...........52

4.2.4 Estudo do efeito das condições de processamento na degradação do

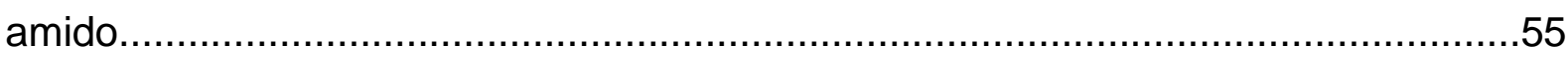

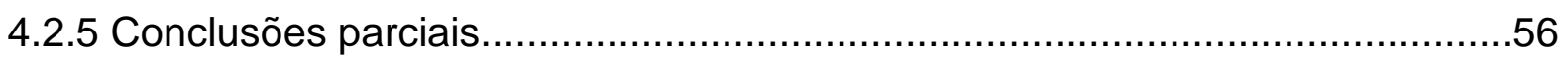

4.3 Estudo do efeito da composição amido de arroz/glicerol nas propriedades físico-

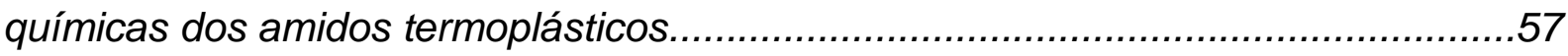

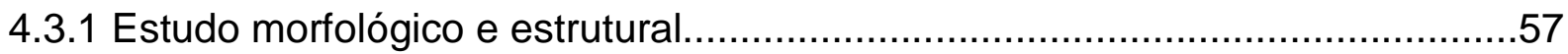

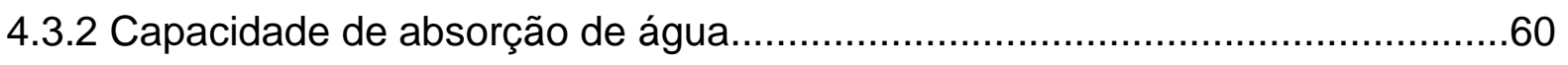

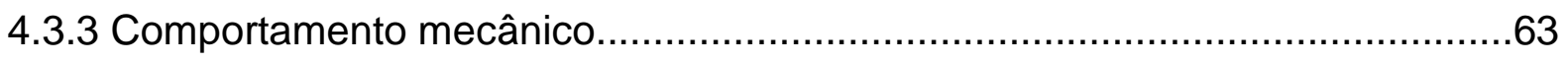

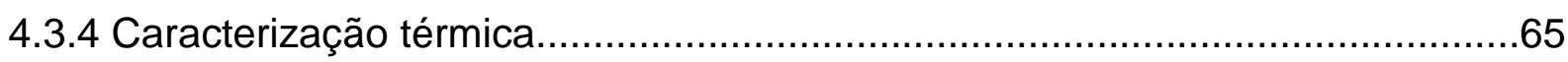

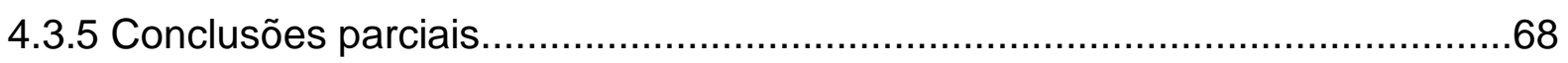

4.4 Estudo da influência da incorporação de palha de arroz nas propriedades dos termoplásticos preparados a partir de amido de arroz............................................69

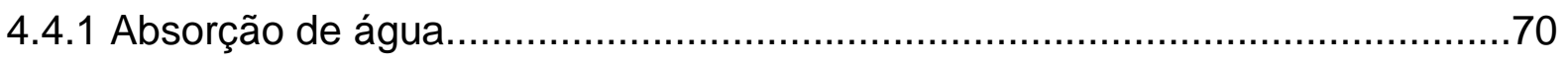

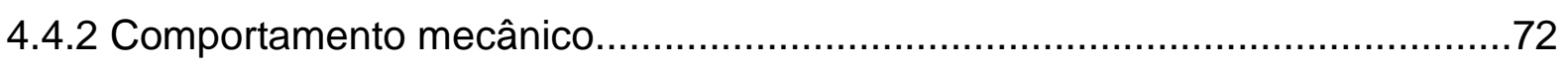

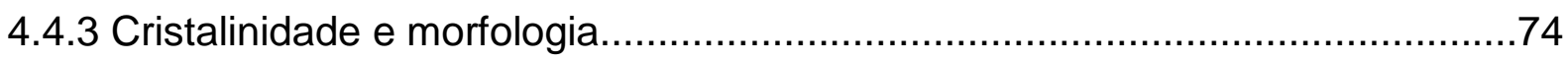

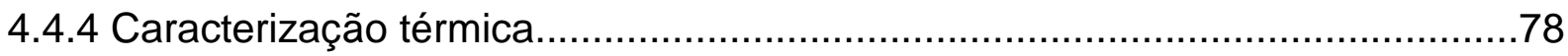

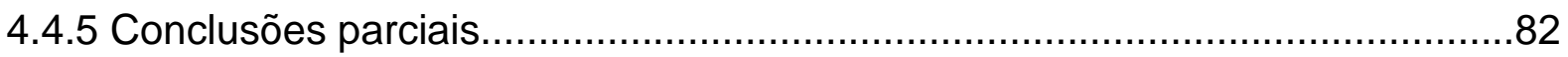


4.5 Avaliação do comportamento do grão de arroz e quirera na preparação de termoplásticos....................................................................................... 83

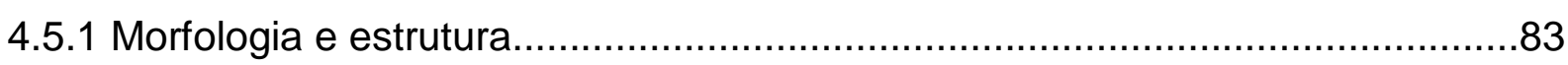

4.5.2 Comportamento mecânico e capacidade de absorção de água......................86

4.5.3 Caracterização térmica.................................................................. 89

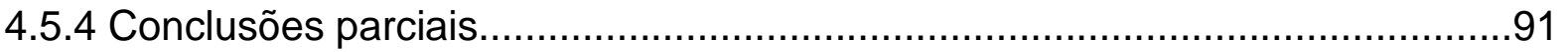

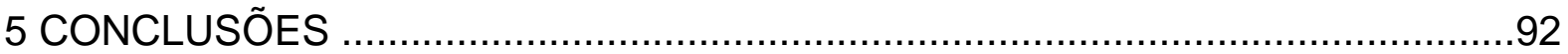

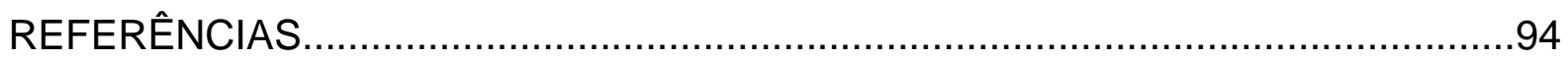




\section{INTRODUÇÃO}

Os crescentes problemas ambientais ocasionados pelo grande consumo de materiais plásticos têm despertado o interesse da comunidade científica na busca de materiais de fácil biodegradabilidade. O desenvolvimento destes materiais tem como intuito o aproveitamento dos recursos naturais oriundos de fontes renováveis, redução no volume de rejeitos e compostabilidade do produto final.

Um segmento dos materiais biodegradáveis que vem obtendo grande interesse da comunidade científica é a utilização do amido. Além de constituir uma substância de reserva de várias plantas, é ainda fonte de energia para muitos organismos, inclusive o homem. Além disso, sua abundância, sua versatilidade e seu baixo custo em relação aos polímeros sintéticos oferecem uma alternativa tecnológica promissora no ramo de plásticos biodegradáveis. Há a possibilidade de sua incorporação em objetos de curto ciclo de uso, como em potes para o plantio, embalagens, proteção de equipamentos contra impactos no transporte e pratos e talheres descartáveis.

As fontes de amido são diversas, sendo que as mais utilizadas tanto para consumo humano quanto industrial são os cereais, como trigo, milho e arroz; os tubérculos, como a batata; e as raízes, como a mandioca.

Dentre as diferentes fontes de amido, a utilização de arroz para a obtenção de termoplásticos é ainda pouco estudada e devido às suas características particulares, pode levar a produtos com desempenho diferenciado.

\subsection{0 amido}

O amido é a principal substância de reserva nas plantas superiores e fornece de 70 a $80 \%$ das calorias consumidas pelo homem. Trata-se de uma matéria-prima renovável, biodegradável e não tóxica (VAN DER BURGT et al., 2000). Depois dos açúcares mais simples (sacarose, glicose, frutose, maltose), é o principal carboidrato que os vegetais superiores sintetizam a partir da fotossíntese, sendo um dos polímeros naturais mais abundantes, juntamente com a celulose (CEREDA, 2002).

O grânulo de amido é constituído de dois componentes poliméricos principais, a amilose e a amilopectina. A amilose possui ligações glicosídicas $\alpha-(D)-1-4$ que the 
confere conformação helicoidal, enquanto que a amilopectina é ramificada, com ligações glicosídicas $\alpha-(D)-1-4$ (cadeia principal) e $\alpha-(D)-1-6$ (ramificações) (JAROWENKO,1997). A proporção entre estes dois constituintes é dependente da origem botânica do amido, porém a maioria dos amidos contém de 20 a $30 \%$ de amilose e 70 a $80 \%$ de amilopectina. A figura 1.1 apresenta as representações das estruturas químicas da amilose e da amilopectina.

Figura 1.1.1 - Estrutura química da amilose (a) e da amilopectina (b).

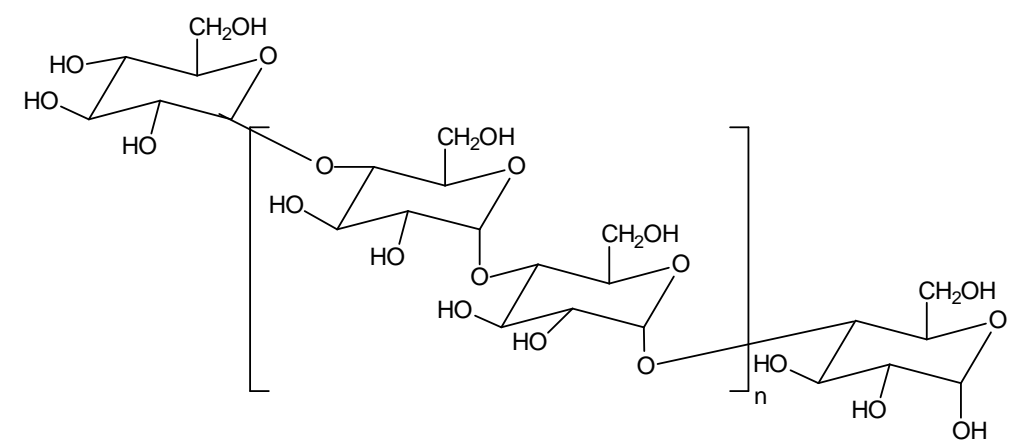

(a)

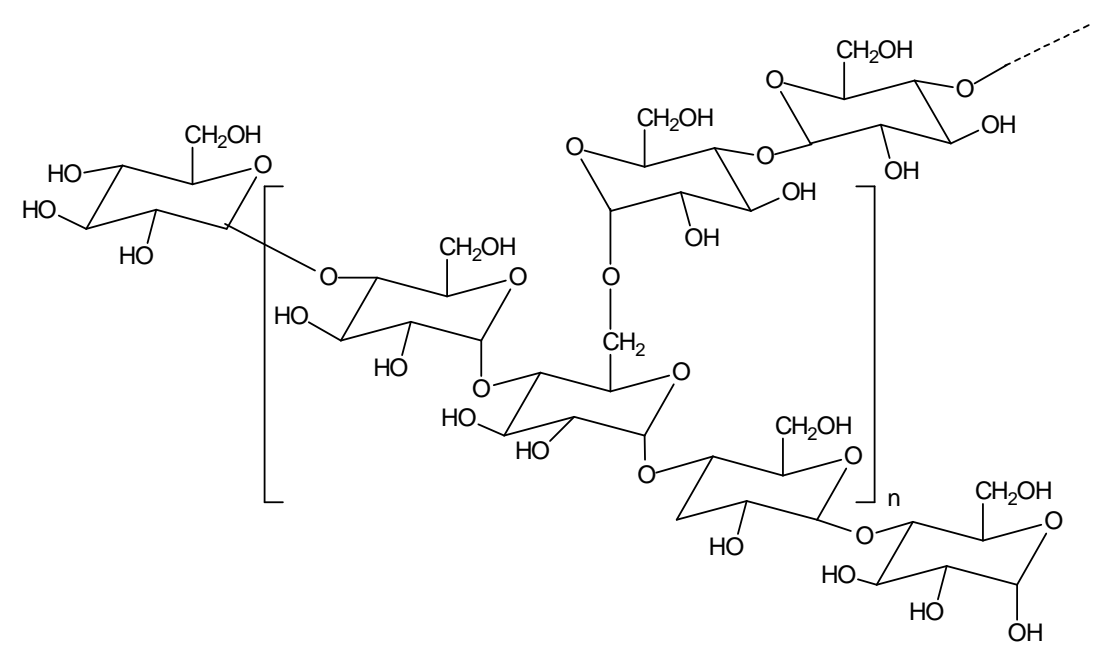

(b)

Fonte: CARVALHO, 2002.

À medida que a planta produz moléculas dos polímeros amilose e amilopectina, estes se depositam em camadas sucessivas ao redor de um ponto central, o hilo, para formar um grânulo compacto. Os grânulos são considerados partículas semi-cristalinas e insolúveis em água fria. Além da amilose e amilopectina, 
outros componentes como proteínas e lipídeos podem ser encontrados na superfície granular. A presença de lipídeos faz com que haja uma redução na capacidade do amido ligar-se com água, portanto diminui a solubilidade do grânulo. Outros componentes como cálcio, fósforo, magnésio, potássio e sódio também podem ser encontrados em pequenas quantidades (menos que 4\%) (CEREDA, 2002).

A amilose apresenta massa molar da ordem de $10^{5}$ a $10^{6} \mathrm{~g} / \mathrm{mol}$ e seu grau de polimerização médio é de 300 a 4900 (COULTATE, 2002; TESTER;KARKALAS; QI, 2004). Apesar de ser uma molécula essencialmente linear, praticamente não contribui para a cristalinidade do grânulo. A amilose na conformação helicoidal possui no interior da hélice átomos de hidrogênio e na parte externa os grupos hidroxilas (BULÉON et al., 1998).

Já a amilopectina possui massa molar da ordem de 50 a $50010^{6} \mathrm{~g} / \mathrm{mol}$ e grau de polimerização $10^{4}$ a $10^{5}$ (CEREDA, 2002; COULTATE, 2002; TESTER; KARKALAS; QI, 2004). O comprimento das ramificações varia entre 20 e 30 unidades de glicose (CEREDA, 2002). O modelo estrutural para a amilopectina mais citado na literatura é o modelo tipo clusters (COULTATE, 2002), apresentado na figura 1.1.2. Nesse modelo, as moléculas de amilopectina apresentam dois tipos de cadeia, sendo algumas cadeias mais ramificadas e outras cadeias mais curtas que formam os clusters. A organização das regiões amorfas e cristalinas alternadas forma camadas concêntricas que contribuem para o crescimento do anel. Na região cristalina pares de cadeias vizinhas formam hélices duplas que são responsáveis pela cristalinidade do grânulo de amido. 
Figura 1.1.2 - Modelo de clusters proposto para a molécula de amilopectina: (a) Modelo de cluster; (b) Organização das regiões amorfas e cristalinas; (c) orientação das moléculas de amilopectina numa seção do grânulo e (d) Formação de estruturas tipo hélice dupla relacionadas com o grau de cristalinidade no grânulo.

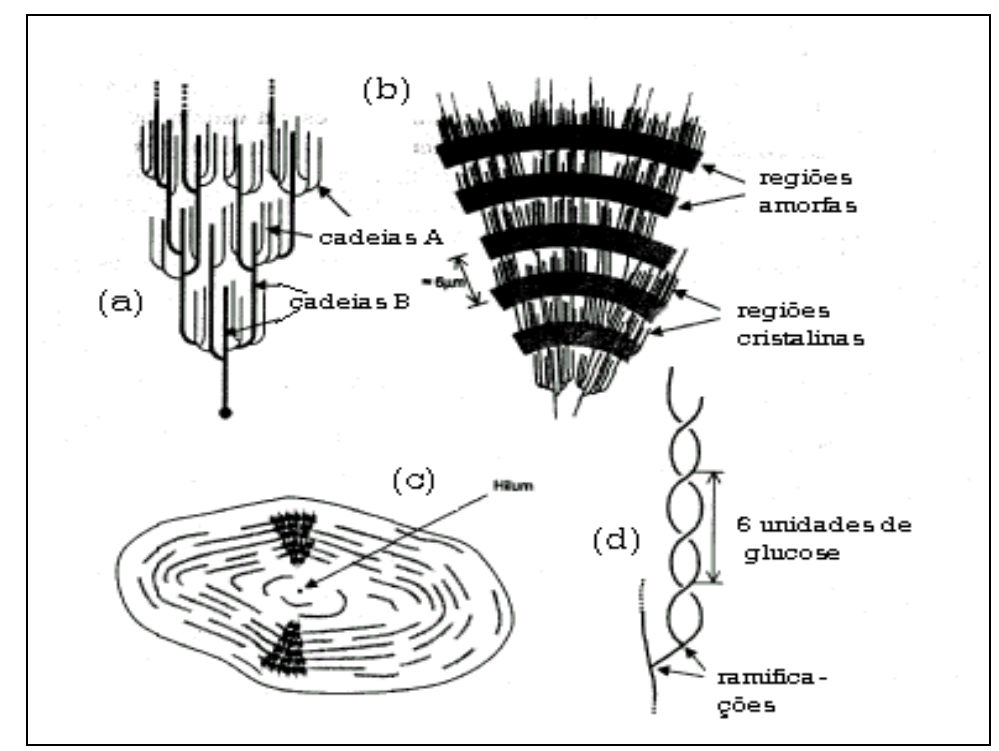

Fonte: COULTATE, 2002.

Dependendo do empacotamento em dupla hélice das cadeias ramificadas de amilopectina, as estruturas cristalinas dos grânulos de amido podem ser classificadas em tipo-A (cerais como milho e arroz), tipo-B (tubérculos como a batata) e tipo-C (raízes como a mandioca), sendo que cada um destes padrões de cristalinidade resultam em diferentes perfis de difração de raios-X. Segundo Cereda (2002), amidos com padrão de cristalinidade tipo-B possuem maiores proporções de cadeias longas que os dos tipos $\mathrm{A}$ e $\mathrm{C}$, já os amidos com padrão do tipo-A, possuem amilopectinas com alta quantidade de cadeias ramificadas e os com padrão do tipo$C$ possuem arranjos intermediários entre $A$ e $B$ (CEREDA, 2002).

A amilose, apesar de não contribuir para a cristalinidade do grânulo de amido, após o processo de gelatinização pode se complexar com agentes complexantes tais como lipídeos, induzindo a formação de hélices simples que caracterizam o padrão de cristalinidade do tipo-V (GELDERS et al., 2004).

A gelatinização do amido é um processo no qual componentes mais solúveis como a amilose, se dissociam e difundem-se para fora do grânulo, o que ocorre quando a água é incorporada na estrutura do grânulo e há presença de aquecimento. A temperatura de ocorrência desse processo é chamada de temperatura de gelatinização. Com a gelatinização há um aumento da viscosidade 
do meio, atingindo seu máximo na temperatura de gelatinização, quando as regiões cristalinas do grânulo desaparecem (TEIXEIRA, 2007).

Quando a suspensão resultante da gelatinização é mantida em repouso, as moléculas de amido gelatinizado começam a se reassociar de forma ordenada e a água é exudada. Este processo é conhecido como retrogradação do amido e é específico para amilose (COULTATE, 2002).

Com relação à origem vegetal dos amidos, pode-se dizer que as propriedades diferentes das fontes são atribuídas principalmente ao teor de amilose no grânulo. Outras características que variam conforme a origem botânica do amido são a cristalinidade, a forma e o tamanho do grânulo e o teor de outros constituintes, como por exemplo o teor de lipídeos (tabela 1).

Tabela 1.1.1 - Características de amidos de diferentes origens botânicas.

\begin{tabular}{ccccc}
\hline Origem Botânica & Forma & Diâmetro $(\mu \mathrm{m})$ & $\%$ amilose & \% lipídeos \\
\hline CEREAIS & & & & \\
Milho & Poliédrico & 5 a 25 & 30 & 0,60 \\
Arroz & Poliédrico & 3 a 8 & 8 a 30 & 0,50 \\
\hline $\begin{array}{c}\text { TUBEROSAS } \\
\text { Mandioca }\end{array}$ & Esférico & 5 a 35 & 20 a 25 & 0,10 \\
Batata & Elipsoidal & 15 a 100 & 18 a 20 & 0,05 a 0,10 \\
\hline Fonte: MESTRES, 1996 & & & &
\end{tabular}

Fonte: MESTRES, 1996.

Entre os cereais, o arroz é o que pode apresentar maior variação natural de amilose (CEREDA, 2002). Os cereais apresentam elevados teores de lipídeos, que não podem ser retirados com muita facilidade do cereal por ocasião da extração, e, como conseqüência, parte dos lipídeos permanece nos grânulos de amido. Ainda, dentre as diversas origens botânicas de amido, o arroz é uma das que apresenta as menores dimensões de grânulos. Por estas características peculiares, a utilização de amido de arroz, que ainda é pouco estudada, pode levar a produtos com desempenho diferenciado. 


\subsection{O arroz}

O arroz (Oryza sativa) é uma das mais importantes matérias primas para a alimentação brasileira, sendo consumido principalmente na forma de grãos inteiros, descascados e polidos. Segundo a Companhia Nacional de Abastecimento (2011), a safra nacional 2010/2011 atingiu uma produção de 13 733, 2 mil toneladas de arroz (CONAB, 2011). O Brasil é o sétimo maior produtor deste cereal (LIMBERGER et al., 2008).

A planta do arroz, apresentada na figura 1.2.1 (A), é constituída em órgãos vegetativos (raízes, caule e folhas) e em órgãos florais, que compreende a panícula constituída por um conjunto de espiguetas (FONSECA et al., 2008). O grão de arroz com casca (figura 1.2.1 (B)) compreende o ovário desenvolvido e consiste da cariopse e de uma camada protetora, a casca, composta por duas folhas modificadas, a pálea e a lema. A cariopse é formada por diferentes camadas, sendo as mais externas o pericarpo (película resultante das paredes do ovário), 0 tegumento e a camada de aleurona (provenientes das paredes do óvulo). $O$ pericarpo se divide em epicarpo, mesocarpo e endocarpo. O endosperma se origina da união do óvulo com o grão de pólen e forma a maior parte do grão, consistindo de células ricas em grânulos de amido e com alguns corpos protéicos que são reservas nutricionais a serem fornecidas ao embrião durante o processo de germinação. $O$ embrião está localizado na parte inferior ventral e é rico em proteínas e lipídeos (WALTER; MARCHEZAN; AVILA, 2008; FONSECA et al, 2008). 
Figura 1.2.1 - (A) Planta do arroz, (B) grão de arroz com casca.

(A)

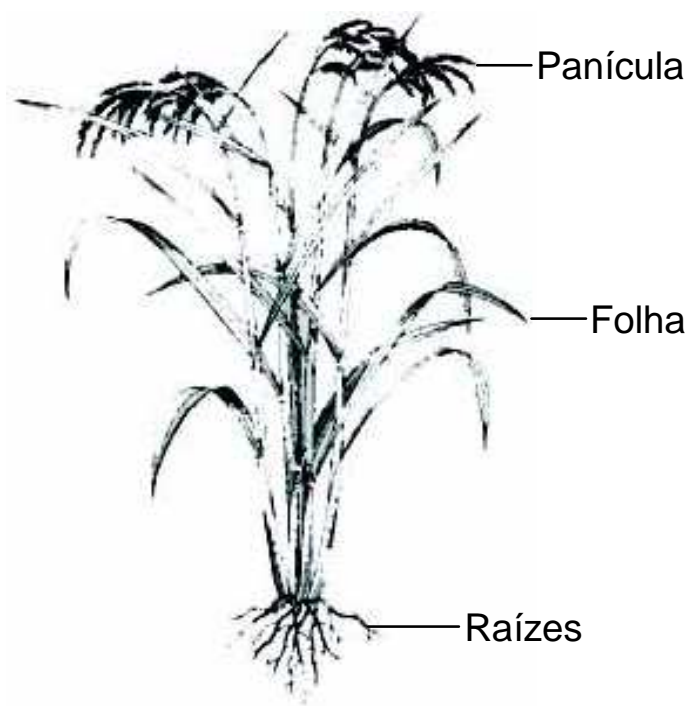

(B)

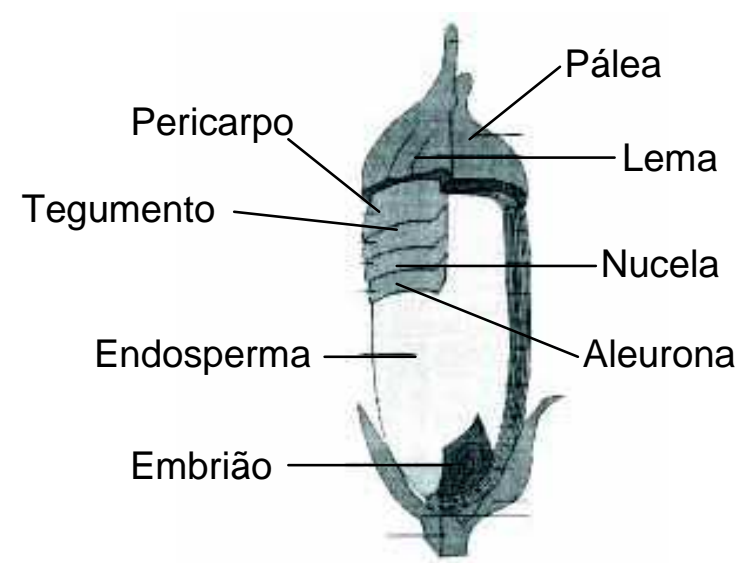

Fonte: GUIMARÃES; FAGERIA; FILHO, 2002.

O beneficiamento industrial do arroz (figura 1.2.2) consiste no descascamento, brunição ou polimento do grão, separação entre as frações de grãos quebrados e inteiros e classificação dos grãos quebrados em grandes, médios ou quirera (CASTRO et al., 1999). As proporções aproximadas de produtos e subprodutos do processamento do arroz são apresentadas na figura 1.2.2. A quirera e grãos quebrados são originados devido ao efeito da aplicação de força mecânica externa aos grãos durante o polimento ou por características internas do próprio grão como fissuras e pequenas trincas (NABESHIMA; EL-DASH, 2004). 
Figura 1.2.2 - Esquema ilustrativo do processo de beneficiamento do arroz.

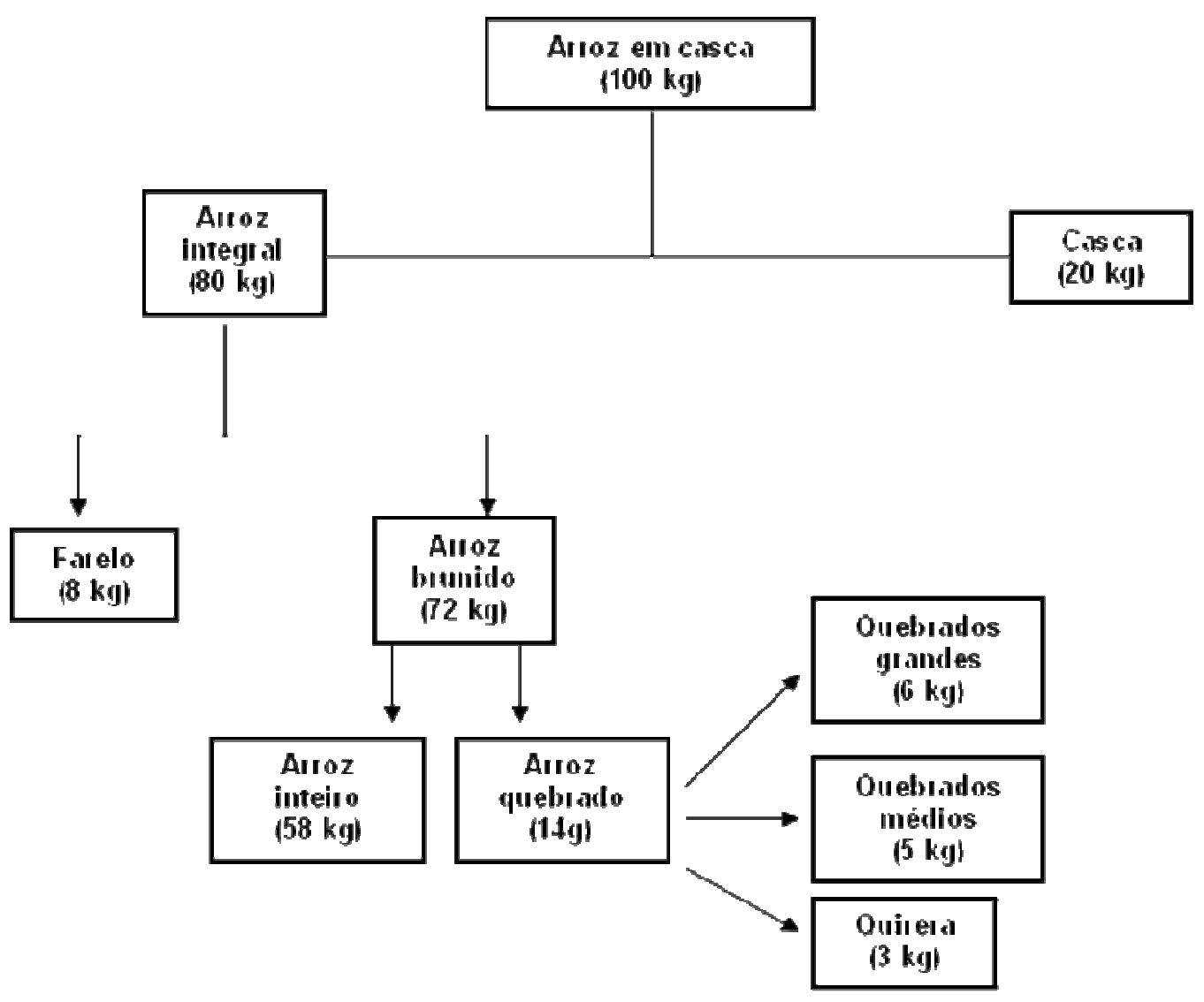

Através da descascagem separa-se a casca da cariopse, obtendo-se o grão integral. O polimento promove a remoção do farelo que é constituído pelo pericarpo, tegumento, camada de aleurona e embrião (WALTER; MARCHEZAN; AVILA, 2008).

A tabela 1.2.1 apresenta a composição química do grão de arroz integral, grão polido e quirera. 
Tabela 1.2.1 - Composição química (\%) do arroz integral, polido e quirera.

\begin{tabular}{cccc}
\hline Constituinte & Arroz integral & Arroz polido & Quirera \\
\hline Amido & 74,12 & 87,58 & 86,4 \\
Proteínas & 10,46 & 8,9 & 8,28 \\
Lipídeos & 2,52 & 0,36 & 1,14 \\
Fibras & 11,76 & 2,87 & 0,46 \\
Cinzas & 1,15 & 0,15 & 0,50 \\
\hline
\end{tabular}

Fonte: LIMA et al, 2000; GENEROSO et al, 2008; WALTER; MARCHEZAN; AVILA, 2008; LIMBERGER et al., 2009.

A casca ou palha do arroz, subproduto resultante do processo de beneficiamento, possui baixo valor nutritivo, entretanto apresenta alta dureza, fibrosidade e natureza abrasiva. Uma grande quantidade desta casca é aproveitada dentro da própria usina de beneficiamento do arroz, onde, a partir de sua combustão, é gerado calor para a parboilização (processo de melhora da qualidade nutricional do arroz em relação ao produto polido) e secagem dos grãos (DELLA; KUNH; HOTZA, 2001).

A lema e a pálea da casca de arroz são órgãos homólogos e apresentam estrutura interna similar. São compostas por epiderme superior (lado externo), esclerênquima (ao centro), parênquima (parte mais interna) e epiderme inferior (figura 1.2.3) (SILVA, 1997). 
Figura 1.2.3 - Estrutura interna da casca de arroz: a) tricoma, b) epiderme superior, $c$ ) esclerênquima, d) parênquima, e) epiderme inferior, f) feixe vascular, g) estômato, h) vest[igio de pequeno tricoma.

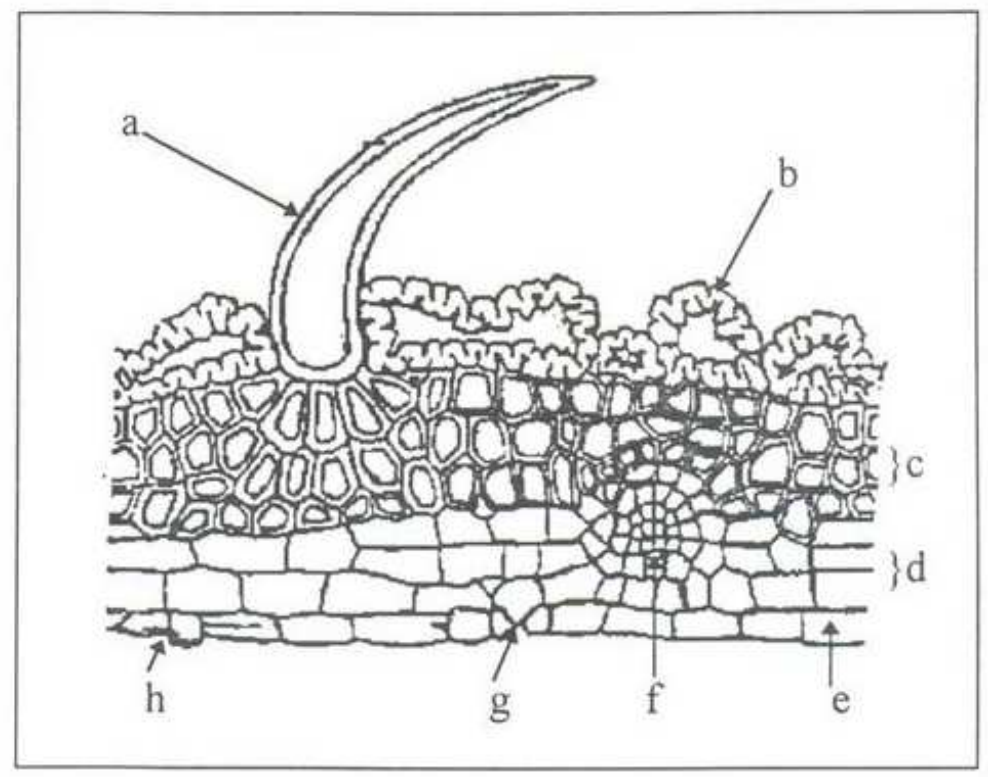

Fonte: SILVA, 1997.

A sílica presente na casca de arroz está distribuída principalmente na epiderme superior, proporcionando a rigidez desta (JAUBERTHIE et al., 2000). Sua forma prevalecente é sílica-gel e está distribuída entre os componentes orgânicos da parede celular: celulose, lignina e hemiceluloses (FOLETTO et al., 2005).

As células da epiderme superior estão distribuídas regularmente e paralelamente ao eixo longitudinal. Existe uma fileira de células comprimidas entre essas células silificadas a partir das quais se desenvolvem os tricomas (pêlos). A epiderme inferior é composta por uma monocamada de células finas distribuídas irregularmente e sem deposição de sílica (SILVA, 1997).

Quanto à composição química, a casca de arroz é constituída principalmente por celulose (25 a 35\%), lignina (26 a 31\%), hemiceluloses (18 a 21\%) e sílica (15 a 17\%) (GERARDI et al., 1998; MANSARAY; GHALY, 1998; STEFANI et al., 2005 LEIVA et al., 2007).

A celulose é encontrada na parede celular de materiais lignocelulósicos na forma de microfibrilas envolvidas numa matriz formada por lignina e hemiceluloses. As microfibrilas de celulose apresentam regiões amorfas e regiões cristalinas, portanto é um polímero semi-cristalino (LUDUEÑA et al., 2011). 


\subsection{0 amido termoplástico}

O amido não é um material termoplástico em sua forma granular. Quando o amido é processado com plasticizante sob efeito de forças de cisalhamento e calor, a estrutura cristalina granular pode ser destruída, formando uma fase contínua, chamada de amido desestruturado ou amido termoplástico (TPS). A esse processo se dá o nome de plasticização (AVÉROUS, 2004). Durante a plasticização, as moléculas de plasticizante substituem as ligações de hidrogênio intra e intermolecular dos grânulos de amido, ocasionando a destruição da cristalinidade granular (MA; YU, 2004).

O agente plasticizante deve ser polar, hidrofílico e compatível com a base do filme polimérico. Além disso, o seu ponto de ebulição deve ser alto o suficiente para evitar a sua evaporação durante o processamento e secagem do TPS (MENDES, 2009).

A água, além de ser um agente de processo (proporciona o inchamento dos grânulos e subsequente desestruturação), atua também como agente plasticizante. No entanto, é necessário a adição de um outro plasticizante para obtenção de materiais mais flexíveis e facilitar a processabilidade (FORSELL et al., 1997). Os polióis, tal como o glicerol, são os agentes plasticizantes mais utilizados para preparação de amido termoplástico (MA; YU, 2004; PUSHPADASS; MARX; HANNA, 2008).

O teor e a natureza química do plasticizante utilizado influenciam propriedades dos TPS tais como temperatura de transição vítrea, cristalinidade e desempenho mecânico.

Após o processamento, três tipos de cristalinidade podem ser observados para os TPS: cristalinidade induzida pelo processamento, cristalinidade induzida pelo envelhecimento ou densificação e cristalinidade residual. A cristalinidade induzida pelo processamento tem sua origem na recristalização da amilose com agentes como lipídeos e polióis, formando hélices simples que caracterizam o padrão de cristalinidade do tipo-V. Dependendo da hidratação, os complexos $V$ podem se apresentar como anidros $\left(\mathrm{V}_{\mathrm{a}}\right)$, com $2 \theta=20,6^{\circ}$; ou como hidratados $\left(\mathrm{V}_{\mathrm{h}}\right.$, com $2 \theta=19,6^{\circ}$ ) (VAN SOEST et al., 1996; VAN SOEST; VLIEGENTHART, 1997). 
A cristalinidade residual tem sua origem na desestruturação incompleta dos grânulos de amido e caracteriza-se pelo padrão de cristalinidade do tipo-B, com picos de $2 \theta \sim 17^{\circ}$ (VAN SOEST et al., 1996; VAN SOEST; VLIEGENTHART, 1997).

Quando o condicionamento do material ocorre em temperaturas acima da temperatura de transição vítrea, pode ocorrer a recristalização ou reorientação das cadeias de amilose (retrogradação). Também ocorre a cristalização da amilopectina, resultando em cristalinidade do tipo-B. Tal processo é identificado como densificação (FORSSELL et al., 1999). O envelhecimento ocorre quando o material é armazenado em temperatura abaixo da sua temperatura de transição vítrea. Há formação de cristalinidade do tipo-B e pequena recristalização da amilose. Tanto o envelhecimento como a densificação ocorrem principalmente devido ao tempo e a umidade do meio (FORSSELL et al., 1999).

Durante o processamento do TPS pode ocorrer degradação do amido principalmente devido ao processo de cisão da cadeia induzida pelo cisalhamento. As frações do material com maiores massas moleculares são as mais afetadas. $O$ aumento da temperatura e a diminuição do teor de plasticizante também contribuem para o aumento da degradação do amido durante o processamento (CARVALHO, 2002).

A pesquisa voltada ao estudo de amido termoplástico aponta algumas limitações para o uso deste material devido à sua baixa resistência mecânica e à sua alta higroscopicidade. Esforços visando sanar estas limitações têm levado ao estudo de blendas e compósitos poliméricos, nos quais a mistura com polímeros sintéticos ou naturais e a adição de fibras (vegetais ou sintéticas) levam a um melhor desempenho mecânico e maior resistência à umidade (CURVELO; CARVALHO; AGNELLI, 2001; CARVALHO; CURVELO; AGNELLI, 2002; CARVALHO et al., 2003; MORAIS; CURVELO; ZAMBON, 2005; CORRADINI et al, 2007).

Trabalhos envolvendo o uso de fibras vegetais como reforço em TPS (CURVELO; CARVALHO; AGNELLI, 2001; AVÉROUS; BOQUILLON, 2004; TAKAGl; ICHIHARA, 2004) têm mostrado que as fibras podem melhorar as propriedades mecânicas dos materiais, assim como propiciar a redução de sua higroscopicidade.

Da mesma forma que as fibras, a introdução de proteína em TPS também proporciona melhora de algumas propriedades mecânicas e reduz a absorção de água. Corradini et al. (2007) verificaram que a introdução da proteína de milho zeína 
ao amido de milho plasticizado com glicerol acarretou num aumento do módulo de Young e na tensão na ruptura em todas as composições estudadas. A absorção de água pelas blendas apresentou valores intermediários entre os componentes puros (amido e zeína) (CORRADINI et al., 2007).

$O$ uso de cargas minerais também tem sido relatado na literatura como possibilidade de reforços para TPS (CARVALHO; CURVELO; AGNELLI, 2001; YU, DEAN; LI, 2006).

As características dos amidos termoplásticos são funções das matérias primas empregadas (amido, plastificante, cargas, reforços) e do processamento escolhido para a realização da mistura destes componentes. As características que dificultam a obtenção de amidos industriais a partir do arroz podem representar alguma vantagem para a produção de amidos termoplásticos. Assim, a presença de proteínas, gordura e fibras nos grãos de arroz e em seus subprodutos podem contribuir tanto para a redução da absorção de umidade quanto para um melhor desempenho mecânico.

Além das características do amido, grãos de arroz e subprodutos do arroz (grãos quebrados e quirera), um outro subproduto do processo de beneficiamento do arroz, a palha, também pode contribuir para preparação de compósitos com melhor desempenho. A palha é composta essencialmente por celulose, na forma de fibras, o que lhe traz a característica de agente de reforço. Além da celulose, sílica também está presente em sua composição.

Dentre as diferentes fontes de amido, a utilização de arroz é ainda pouco estudada para obtenção de termoplásticos. Prachayawarakorn, Ruttanabus e boonsom (2011) estudaram a influência do teor e comprimento das fibras de algodão introduzidas na matriz de amido de arroz plasticizada com glicerol. Observaram que a introdução das fibras contribuiu para redução da absorção de água, já os valores para módulo elástico e tensão máxima aumentaram com a introdução das fibras de algodão (PRACHAYAWARAKORN; RUTTANABUS; BOONSOM, 2011).

$\mathrm{O}$ estudo de matrizes de termoplásticos preparados com amido de arroz e glicerol e reforçadas com fibra de algodão ou polietileno de baixa densidade também demonstrou que a introdução destes componentes reduziu a capacidade de absorção de água pela matriz do TPS e proporcionou maiores valores de módulo elástico e tensão máxima (PRACHAYAWARAKORN; SANGNITIDEJ; BOONPASITH, 2010). 
Neste sentido, a abundância de rejeitos do processamento industrial do arroz e as características estruturais e de composição do amido de arroz representam uma motivação para o estudo de preparação e caracterização de amidos termoplásticos a partir dos grãos de arroz rejeitados no beneficiamento industrial e compósitos com a palha, também rejeitada no processo de beneficiamento. 


\section{OBJETIVOS}

O presente trabalho teve como objetivo o estudo da utilização do amido de arroz como composto base para preparação de amidos termoplásticos. Este estudo foi conduzido de forma a atender aos seguintes objetivos específicos:

- Investigar o efeito das condições de processamento na preparação dos amidos termoplásticos;

- Estudar o efeito da composição amido de arroz/glicerol nas propriedades físico-químicas dos amidos termoplásticos;

- Estudar da influência da incorporação de subproduto do beneficiamento do arroz (palha) nas propriedades dos TPS;

- Avaliar as diversas formas de apresentação do amido de arroz (em grão e quirera) na preparação e nas propriedades obtidas por TPS. 


\section{MATERIAIS E MÉTODOS}

\subsection{Preparação e caracterização dos materiais de partida: quirera, amido, grãos e palha de arroz}

As amostras de grãos de arroz e de seus subprodutos (palha e quirera) foram obtidas em unidades de beneficiamento da região de Rio Claro. $\mathrm{O}$ arroz beneficiado em Rio Claro é do tipo agulinha, plantação de sequeiro e proveniente do Rio Grande do Sul. O amido de arroz empregado foi o comercializado como creme de arroz. Glicerina grau técnico foi empregada como plastificante.

\subsubsection{Preparação dos materiais de partida}

A palha de arroz foi tratada por quatro procedimentos antes de ser incorporada ao TPS. Tais procedimentos foram:

1) Palha inteira, apenas lavada em água corrente (indicado pela letra I na nomenclatura);

2) Palha moída em moinho de facas da marca Marconi, modelo MA 048 (indicado pela letra $\mathrm{M}$ na nomenclatura);

3) Palha imersa em água por $24 \mathrm{~h}$, seguido de aquecimento em banho-maria por $2 \mathrm{~h}$ e desfibrilamento (indicado pela letra $\mathrm{C}$ na nomenclatura);

4) Polpa de palha de arroz obtida por polpação com etanol/água à $180^{\circ} \mathrm{C}$ por 105 minutos (indicado pela letra $P$ na nomenclatura). A mistura etanol/água utilizada como licor de polpação foi na proporção 1:1/v:v. A razão entre licor de polpação e palha foi 10:1 (10g de palha, $100 \mathrm{~mL}$ de licor). As misturas solvente/palha foram colocadas em reatores tubulares de aço inox vedados de $125 \mathrm{~mL}$. Os reatores foram depositados em banho de glicerina na temperatura de $108^{\circ} \mathrm{C}$. Após o tempo estabelecido (105 minutos), os reatores foram colocados em banho de gelo para suspensão da reação. Em seguida, a polpa foi batida e lavada com etanol até que o filtrado resultante se tornar incolor.

Para os demais materiais (grãos de arroz, quirera e amido) não foi necessário tratamento prévio. 


\subsubsection{Caracterização dos materiais de partida}

\subsubsection{Microscopia eletrônica de varredura (MEV)}

As amostras amido de arroz e da palha após os diversos tratamentos prévios foram caracterizadas do ponto de vista morfológico por microscopia eletrônica de varredura (MEV). As amostras foram colocadas sobre a fita adesiva de carbono do suporte metálico e observadas no microscópio eletrônico de varredura modelo LEO440. As amostras foram metalizadas em um metalizador Coating System BAL-TEC MED 020 antes da análise no microscópio.

\subsubsection{Difração de raios-X}

A caracterização estrutural foi feita por difração de raios-X. Os difratogramas de raios- $X$ foram obtidos diretamente do amido, da palha e do grão de arroz. As análises foram realizadas à temperatura ambiente, no intervalo angular de $5-40^{\circ}(2 \theta)$ em um difratômetro Universal de raios-X Rigaku, com eletrodo de cobre operando com potência de $50 \mathrm{kV} / 100 \mathrm{~mA}$, a uma velocidade de $2^{\circ} / \mathrm{min}$. O índice de cristalinidade (Ic) foi determinado de acordo com o método proposto por Hulleman et al. (1999), através da equação 3.1.1 e da figura 3.1.1 (HULLEMAN et al., 1999).

$$
\mathrm{Ic}=\mathrm{Hc} /(\mathrm{Ha}+\mathrm{Hc}) \quad \text { (equação 3.1.1) }
$$

Ha é a altura correspondente à fase amorfa e Hc à altura de pico cristalino. 
Figura 3.1.1 - Exemplo para determinação do índice de cristalinidade.

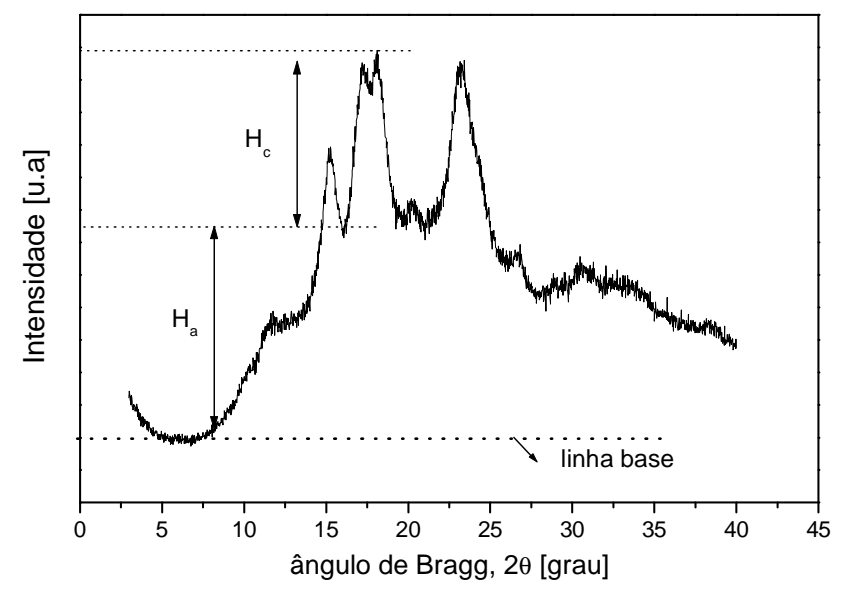

Fonte: HULLEMAN et. al, 1999.

\subsubsection{Termogravimetria (TG)}

A estabilidade térmica do amido de arroz, da quirera, dos grãos de arroz e da palha foi estudada por termogravimetria (TG). O equipamento utilizado foi Shimadzu TA-50WSI com módulo TGA-50. As análises de TG foram realizadas com aproximadamente $10 \mathrm{mg}$ de amostra, atmosfera de $\mathrm{N}_{2}$, fluxo de $20 \mathrm{~mL} / \mathrm{min}$ e em porta-amostra de platina, com intervalo de temperatura da temperatura ambiente à $900^{\circ} \mathrm{C}$, com taxa de aquecimento de $10^{\circ} \mathrm{C} / \mathrm{min}$.

\subsubsection{Teor de umidade}

O teor de umidade da palha submetida aos diversos tratamentos prévios, do amido, quirera e grãos de arroz foi determinado em uma balança para medição de umidade Marte-Ohaus-MB200, após 3 h de medição (tempo necessário para garantir a massa constante) a uma temperatura de $105^{\circ} \mathrm{C}$.

\subsubsection{Teor de amilose}

O teor de amilose do amido de arroz foi determinado através do método de complexação entre a amilose e a enzima L- $\alpha$-lisofosfatidilcolina (LPC), proposto por Mestres et al. (1996) (MESTRES et al., 1996). Conforme este método, as amostras 
foram constituídas de 3,00 mg de amido e $10 \mu \mathrm{L}$ de solução $2 \%$ de LPC, colocados em um porta-amostra de alta pressão para DSC e mantido em repouso por 1 hora antes da análise. A referência foi constituída de $10 \mu \mathrm{L}$ de água. Posteriormente, medidas de DSC foram realizadas empregando-se equipamento Shimadzu TA50WSI com módulo DSC-50 com a programação de temperatura descrita na tabela 3.1.1.

Tabela 3.1.1 - Programação de temperatura para determinação do teor de amilose empregando DSC.

\begin{tabular}{ccc}
\hline Faixa de temperatura & $\begin{array}{c}\text { Razão de } \\
\text { aquecimento/Resfriamento } \\
\left({ }^{\circ} \mathrm{C} / \mathrm{min}\right)\end{array}$ & $\begin{array}{c}\text { Isoterma } \\
(\mathbf{m i n})\end{array}$ \\
\hline $25^{\circ} \mathrm{C}-160^{\circ} \mathrm{C}$ & 10 & 2 \\
$160^{\circ} \mathrm{C}-25^{\circ} \mathrm{C}$ & 5 & 5 \\
$25^{\circ} \mathrm{C}-160^{\circ} \mathrm{C}$ & 10 & 2 \\
$160^{\circ} \mathrm{C}-25^{\circ} \mathrm{C}$ & 5 & 5 \\
\hline
\end{tabular}

\subsubsection{Distribuição da massa molecular}

A distribuição de massa molar para o amido de arroz foi determinada em um cromatógrafo Shimadzu nas seguintes condições:

- Colunas: pré - coluna Ultrahydrogel A + 3 colunas Ultrahydrogel Linear em série

- Eluente: solução $0,1 \mathrm{~N} \mathrm{NaNO} / \mathrm{pH}=11,5$ com solução $1 \mathrm{M} \mathrm{NaOH}$

- Fluxo: $0,8 \mathrm{~mL} / \mathrm{min}$

- Pressão: 22/21 Kgf/ $\mathrm{cm}^{2}$

- Temperatura: $35^{\circ} \mathrm{C}$

- Detector: IR modelo RID- 6 A

- Integrador: Shimadzu Cromatopac C-R7A

A amostra foi preparada a partir da dissolução de $450 \mathrm{mg}$ de amido em $15 \mathrm{~mL}$ de solução $\mathrm{NaOH} 1 \mathrm{M}$ seguido de agitação por 24 horas. $\mathrm{A} 2 \mathrm{~mL}$ da solução 
resultante foram adicionados $4 \mathrm{~mL}$ do eluente seguido de filtração em membrana de fibra de vidro de porosidade de 1,0 $\mu$ m (Milipore/ SLPB DZ5 NZ) sob pressão. O volume de injeção foi de $20 \mu \mathrm{L}$. A curva de calibração foi construída empregando-se soluções de padrões de Pullulan $\left(M_{\mathrm{w}}\right.$ de 180 a $\left.1,60 \times 10^{6} \mathrm{~g} \mathrm{~mol}^{-1}\right)$ na concentração de $0,002 \mathrm{~g}$ por $\mathrm{mL}$ eluente.

\subsection{Estudo das condições de processamento}

As amostras utilizadas para o estudo das condições de processamento dos TPS foram constituídas de amido de arroz e glicerol. O teor de glicerol foi fixado em $30 \%$. Todos os componentes foram colocados em sacos de polietileno e prémisturados via mistura física.

\subsubsection{Reometria de torque}

A reometria foi estudada a partir do processamento das pré-misturas em um reômetro de torque Haake, sistema Rheomix 600 (misturador intensivo), com rotação de $60 \mathrm{rpm}$. Duas sequências de condições foram estudadas, uma mantendo-se a temperatura fixa em $120^{\circ} \mathrm{C}$ e variando-se o tempo em 4, 6, 8, 10 e 12 minutos; outra mantendo-se o tempo máximo de processamento fixo em 8 minutos e variando-se a temperatura em $100,110,120,130$ e $140^{\circ} \mathrm{C}$.

\subsubsection{Avaliação estrutural por difração de raios-X}

A influência das condições de processamento nas características estruturais dos TPS foi estudada por difração de raio- $X$ realizada à temperatura ambiente, no intervalo angular de 5-40ำ $\left({ }^{\circ} 2 \theta\right)$ em um difratômetro Universal de raios-X Rigaku, com eletrodo de cobre operando com potência de $50 \mathrm{kV} / 100 \mathrm{~mA}$, a uma velocidade de $2 \% / m i n$. Os índices de cristalinidade foram determinados conforme descrito no item 3.1.2.2. 


\subsubsection{Análise da morfologia por Microscopia Eletrônica de Varredura (MEV)}

A influência das condições de processamento na morfologia dos TPS foi estudada através de um microscópio eletrônico de varredura modelo LEO-440. As amostras foram submetidas à fratura frágil obtida após congelamento em nitrogênio líquido antes da análise no MEV. As amostras foram metalizadas em um metalizador Coating System BAL-TEC MED 020 antes da análise no microscópio.

\subsubsection{Estudo do efeito das condições de processamento na degradação do amido}

A influência das condições de processamento na degradação do amido foi estudada por cromatografia por exclusão de tamanho (HPSEC). As condições de análise foram semelhantes às descritas no item 3.1.2.6.

\subsection{Preparação e caracterização dos termoplásticos e compósitos}

\subsubsection{Preparação dos termoplásticos e compósitos}

Para os TPS com composição amido de arroz/glicerol foram preparadas prémisturas de amido e plasticizante em um saco de polietileno, sendo que as proporções de glicerol foram 20, 25, 30, 35 e 40\%.

O primeiro passo de preparação das composições amido de arroz/glicerol/palha foi semelhante ao descrito no parágrafo anterior. Para esse conjunto de amostras fixou-se o teor de glicerol em $30 \%$. Os teores de palha foram 1, 234 e 5\%. Todos os componentes (amido, glicerol e palha em seus diversos tratamentos prévios) foram pré-misturados via mistura física, sendo que a palha em polpa úmida foi dispersa com auxílio de espátulas antes de ser incorporada à prémistura amido/glicerol.

As pré-misturas para as composições de grãos de arroz ou quirera e glicerol foram preparadas a partir da imersão dos grãos ou quirera em glicerol por $24 \mathrm{~h}$ seguido de aquecimento em banho-maria por $3 \mathrm{~h}$.

Todas as pré-misturas foram processadas em um misturador intensivo (reômetro de torque Haake, sistema Rheomix 600 ), com rotação de $60 \mathrm{rpm}, 120^{\circ} \mathrm{C}$ 
por 8 minutos e posteriormente foram termoprensadas em moldes para a obtenção de corpos de prova específicos para os ensaios, utilizando-se uma termoprensa da marca Carver. A temperatura utilizada na termoprensagem foi de $120^{\circ} \mathrm{C}$ e tempo de prensagem foi de 10 minutos. Foi realizada uma pré-prensagem à pressão de 2 toneladas métricas, por 8 minutos. Em seguida a pressão foi aumentada para 4 toneladas métricas, por 1 minuto e posteriormente a pressão foi elevada para 8 toneladas métricas, por 1 minuto.

\subsubsection{Caracterização dos termoplásticos e compósitos obtidos}

Todas as composições de termoplásticos e compósitos preparados conforme procedimento descrito no item anterior foram caracterizados de acordo com as metodologias explicadas nos itens que se seguem.

\subsubsection{Estudo morfológico e estrutural}

A morfologia dos TPS e compósitos foi estudada através de um microscópio eletrônico de varredura modelo LEO-440. Os TPS e compósitos foram submetidos à fratura frágil obtida após congelamento das amostras em nitrogênio líquido antes da análise no MEV. As amostras foram metalizadas em um metalizador Coating System BAL-TEC MED 020 antes da análise no microscópio.

As características estruturais foram estudadas por difração de raio- $X$ realizada à temperatura ambiente, no intervalo angular de 5-40ำ (ํㅡ) em um difratômetro Universal de raios-X Rigaku, com eletrodo de cobre operando com potência de 50 $\mathrm{kV} / 100 \mathrm{~mA}$, a uma velocidade de $2 \% / \mathrm{min}$. Os índices de cristalinidade foram determinados conforme descrito no item 3.1.2.2

\subsubsection{Caracterização mecânica}

Os ensaios mecânicos de tração x deformação foram realizados segundo a norma ASTM D638 M-96, utilizando-se uma máquina Emic DL10000, célula de carga de $500 \mathrm{Kgf}$, com velocidade de $50 \mathrm{~mm} \mathrm{~min}^{-1}$. As amostras foram obtidas via termoprensagem e previamente condicionadas em ambiente de umidade relativa de 53\% segundo a norma ASTM E104-85. 


\subsubsection{Caracterização térmica}

A DSC foi empregada para determinar os eventos térmicos que ocorrem com os termoplásticos amido de arroz/glicerol como temperatura de transição vítrea, temperatura de cristalização e temperatura de fusão. Foi utilizado o mesmo equipamento empregado para a determinação do teor de amilose, o mesmo fluxo de gás $(20 \mathrm{~mL} / \mathrm{min})$ e atmosfera $\left(\mathrm{N}_{2}\right)$.

As amostras dos termoplásticos e compósitos foram analisadas quanto à estabilidade térmica por TG. As amostras foram submetidas à TG utilizando-se um equipamento Shimadzu TA-50WSI com módulo TGA-50. As análises de TG foram realizadas com aproximadamente $10 \mathrm{mg}$ de amostra, atmosfera de $\mathrm{N}_{2}$, fluxo de 20 $\mathrm{mL} / \mathrm{min}$ e em porta-amostra de platina, sendo que o intervalo de temperatura foi da ambiente até $900^{\circ} \mathrm{C}$, com taxa de aquecimento de $10^{\circ} \mathrm{C} / \mathrm{min}$.

O comportamento térmico-dinâmico-mecânico foi estudado por técnicas de DMTA. As análises foram realizadas em um equipamento Netzsch modelo DMTA 242C, no modo tensão, equipado com um sistema de resfriamento por suprimento de nitrogênio líquido. Os corpos de prova com espessura de aproximadamente 1 $\mathrm{mm}$ serão condicionados em ambiente com 53\% de umidade relativa seguindo a ASTM E104-85. Os ensaios foram realizados em uma freqüência de $1 \mathrm{~Hz}$, em atmosfera de ar, com pré-carga de $0,01 \mathrm{~N}$ e no intervalo de $-130^{\circ} \mathrm{C}$ a $130^{\circ} \mathrm{C}$.

\subsubsection{Avaliação da capacidade de absorção de água}

Para avaliar a capacidade de absorção de água, os corpos de prova com 8 $\mathrm{mm}$ de diâmetro e aproximadamente $3 \mathrm{~mm}$ de espessura (obtidos via termoprensagem) foram submetidos à diversos ambientes com umidades relativas distintas, obtidas segundo a norma ASTM E 104-85. Em determinados intervalos de tempo os corpos de prova foram pesados. O ensaio prosseguiu até que fosse atingido o equilíbrio, ou seja, até a obtenção de peso constante entre pesagens sucessivas. 


\section{RESULTADOS E DISCUSSÃO}

\subsection{Caracterização dos materiais de partida: amido, palha e grãos de arroz}

\subsubsection{Morfologia}

Através do estudo da morfologia dos grânulos de amido pode-se avaliar a forma e tamanho dos mesmos. A figura 4.1.1 apresenta micrografia obtida por MEV com aumento de 4000 vezes.

Figura 4.1.1 - Micrografia de MEV para o amido de arroz com aumento de 4000 vezes.

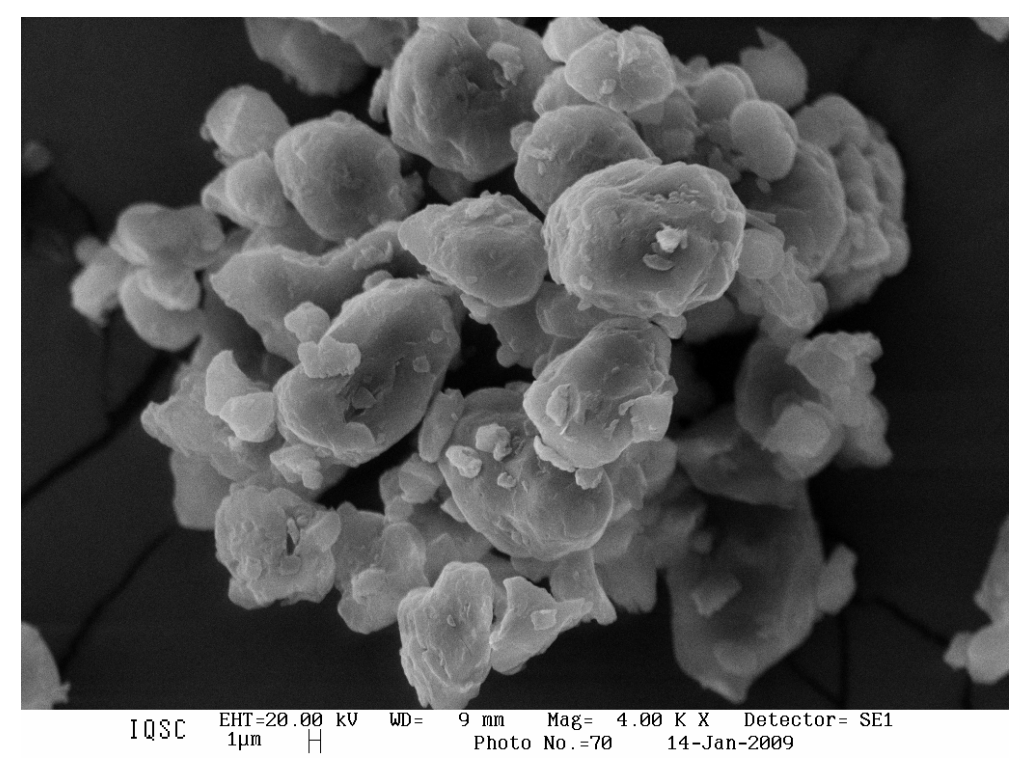

Observa-se que o grânulo de amido de arroz é poliédrico. Seu tamanho médio varia de 2 a $11 \mu \mathrm{m}$. Cereda (2002) e Mestres (1996) também observaram forma poliédrica para o grânulo de amido de arroz e os tamanhos médios obtidos por estes situaram-se na faixa de 2 a $9 \mu \mathrm{m}$ (CEREDA, 2002; MESTRES, 1996).

A figura 4.1.2 mostra as micrografias com aumento de 500 vezes para a palha de arroz inteira, apenas lavada (palha I) e para palha imersa em água por 24h, seguido de aquecimento e desfibrilamento (palha $\mathrm{C}$ ). Os diversos tratamentos aos quais a palha foi submetida, tal qual o tratamento para palha $\mathrm{C}$, visaram a obtenção de uma material de mais fácil dispersão nas amostras de TPS e com maior liberação de fibras, já que são estas os agentes responsáveis pelo reforço. 
Figura 4.1.2 - Micrografias de MEV com aumento de 500x para palha I, superfícies inferior (A) e superior (B); e para palha C, superfícies inferior (C) e superior (D).
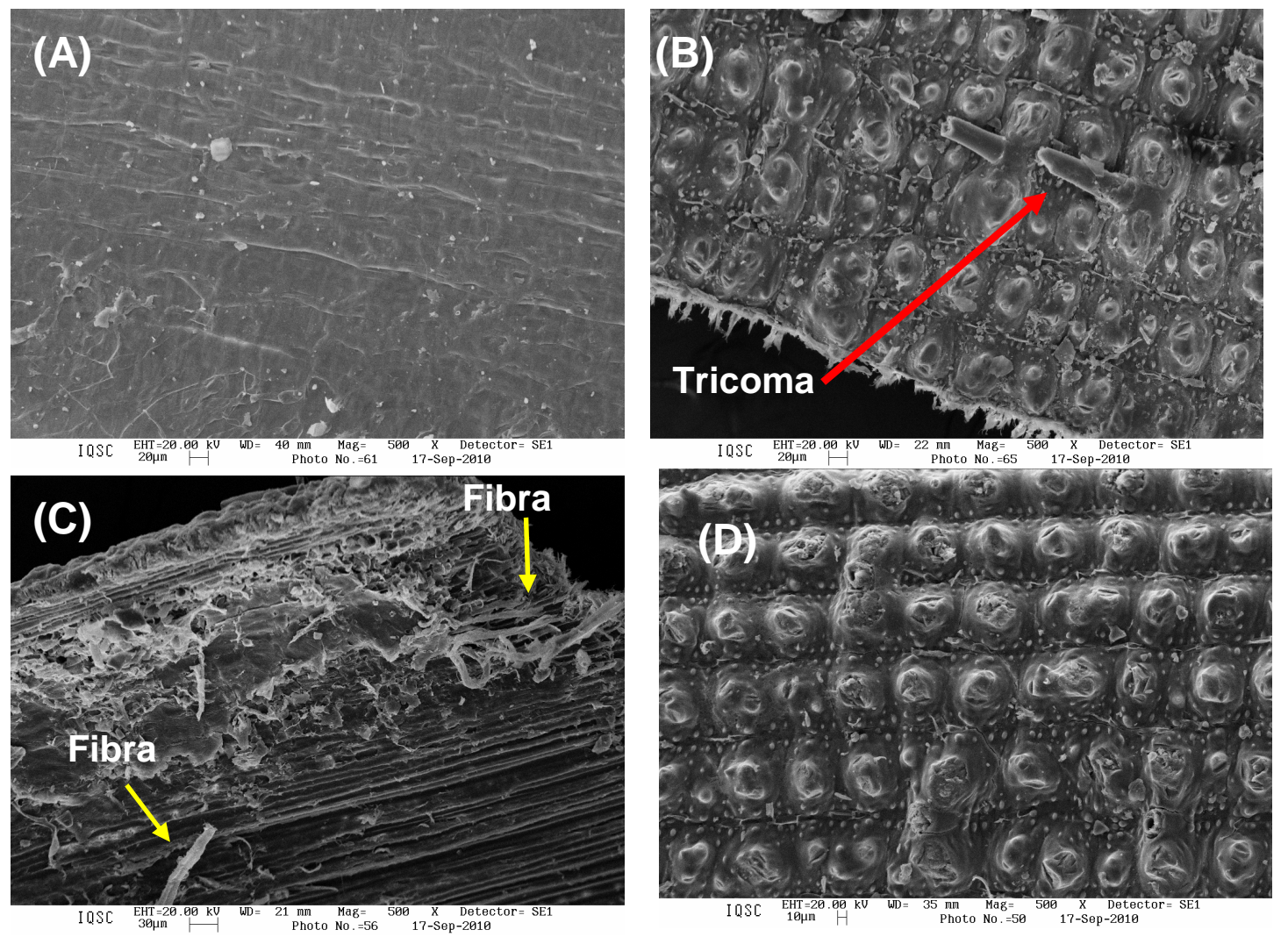

Observa-se que o procedimento utilizado para obtenção da palha C proporcionou algum desgaste tanto na epiderme superior quanto na epiderme inferior da palha de arroz. O desgaste causado na epiderme superior pode ser identificado pela ausência de tricomas, já na epiderme inferior pela menor homogeneidade da superfície. Há pouca evidência de fibras para palha $\mathrm{C}$ e nenhuma para palha I.

As micrografias para palha moída (palha M) são mostradas na figura 4.1.3. Nota-se que o processo de moagem gerou partículas menores, no entanto pouco interferiu nas células da epiderme inferior e superior. Não há evidência de fibras dispersas para palha $\mathrm{M}$. 
Figura 4.1.3 - Micrografias de MEV para palha M: (A) aumento de 250x; (B) superfície superior, aumento de 500x; (C) superfície inferior, aumento de 500x.
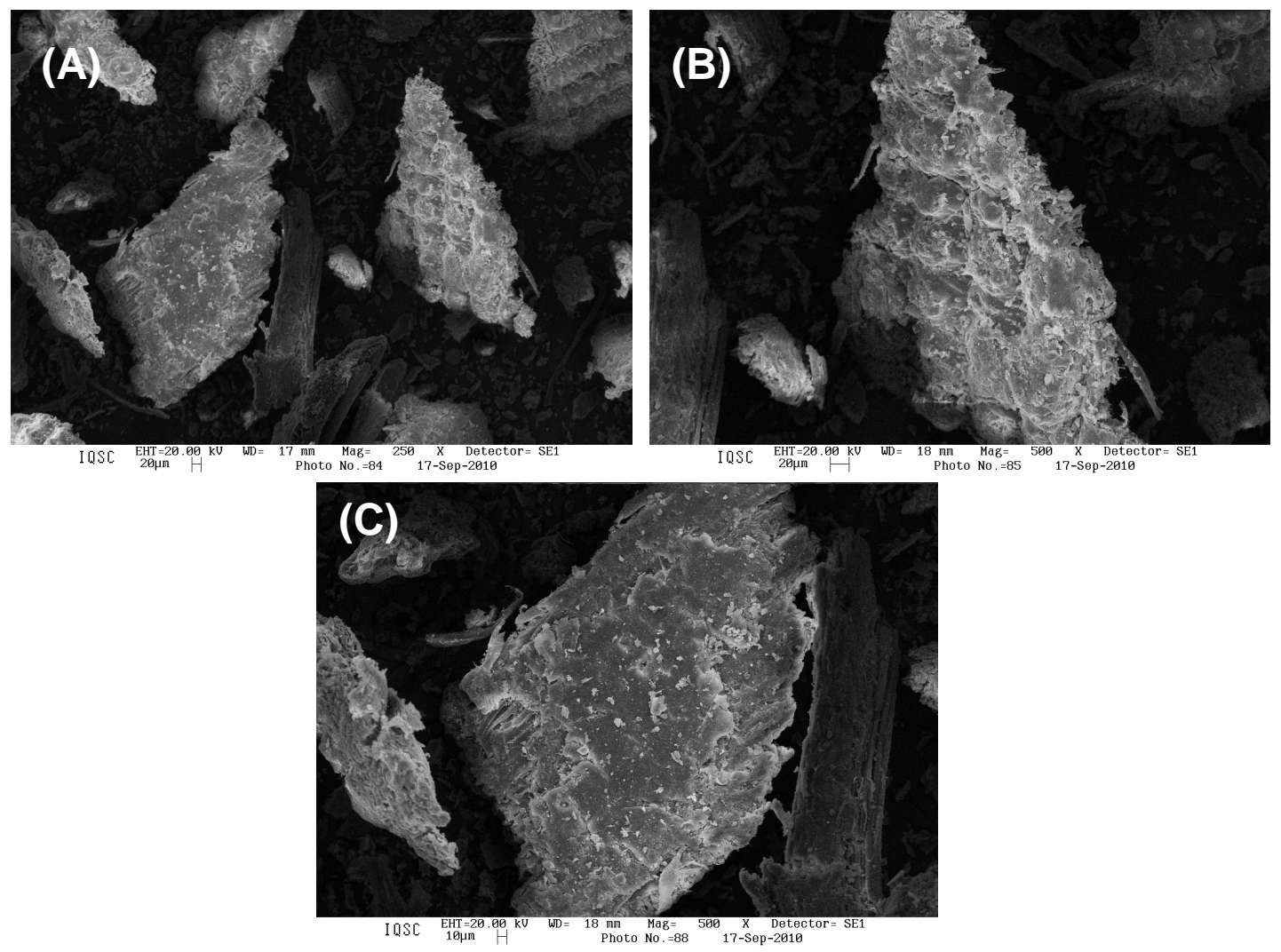

Dentre os tratamentos aos quais a palha de arroz foi submetida, é esperado que a polpação promova maior liberação de fibras, que atuam como reforço em TPS. Através do processo de polpação etanol/água $\left(180^{\circ} \mathrm{C}, 105 \mathrm{~min}\right)$ foi possível a remoção parcial da lignina e das hemiceluloses, com a consequente liberação das fibras, conforme demonstra a figura 4.1.4. A superfície inferior da palha remanescente foi bastante afetada pela polpação. As fibras obtidas apresentaram comprimento em torno de $220 \mu \mathrm{m}$ e diâmetro em torno de $10 \mu \mathrm{m}$. 
Figura 4.1.4 - Micrografias de MEV para palha $P$ : (A) superfície superior, aumento de 250x; (B) superfície inferior, aumento de 500x; (C) fibras, aumento de 500x; (D) fibras, aumento de 1000x.
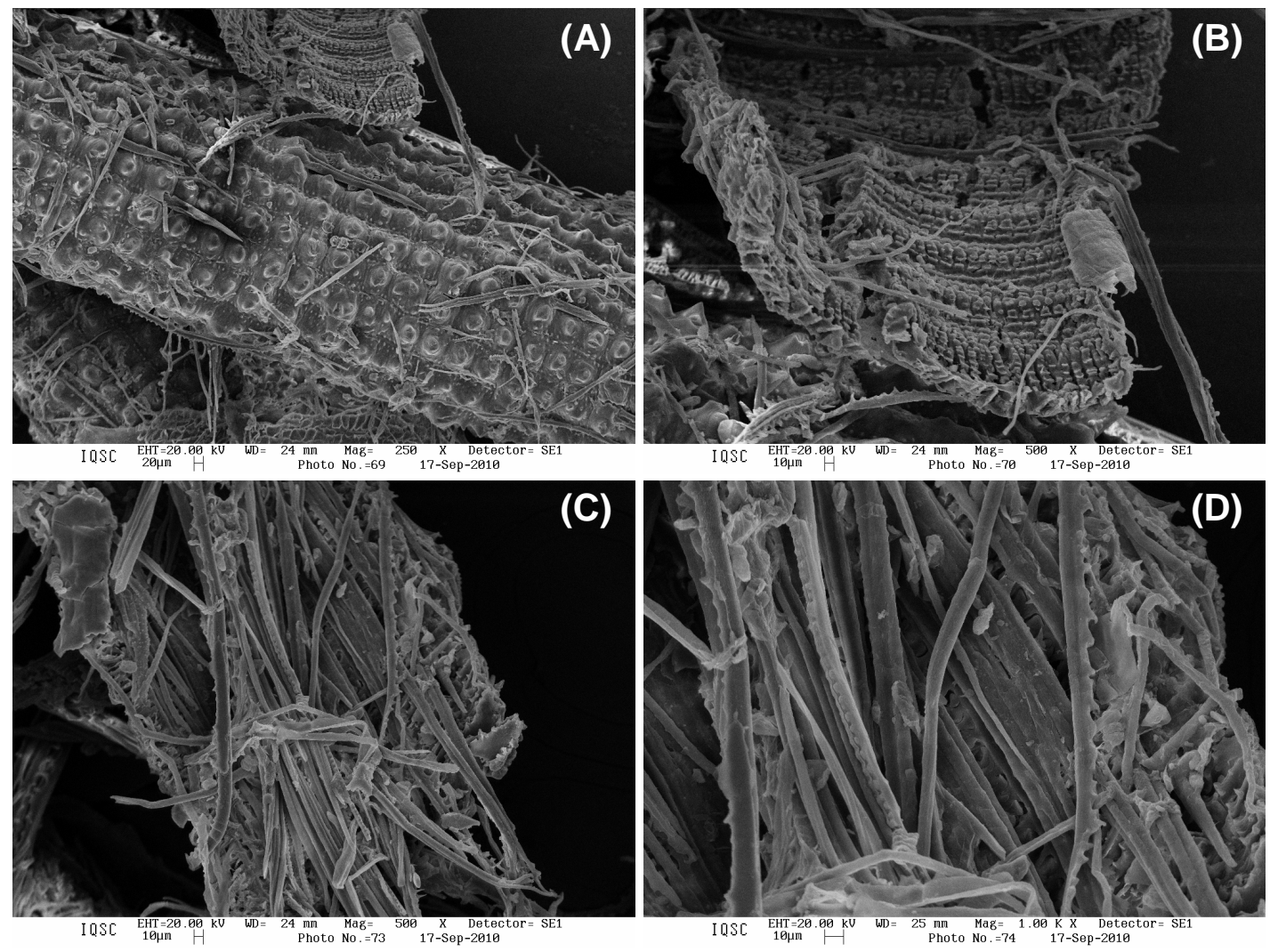

\subsubsection{Cristalinidade}

A cristalinidade dos grânulos de amido está relacionada com a organização das moléculas de amilopectina em seu interior (MOORTHY, 2002), enquanto que a cristalinidade da palha de arroz é devida à estrutura da celulose. As cadeias de celulose se arranjam formando regiões cristalinas intercaladas por regiões amorfas, configurando um material semi-cristalino (FENGEL, 1984). A figura 4.1.5 ilustra os difratogramas de raios-X para a palha, o amido e o grão de arroz. 
Figura 4.1.5 - Difratogramas de raios-X para o amido, grão e palha de arroz $(A)$ e a ampliação do sinal para o amido e grão de arroz (B).
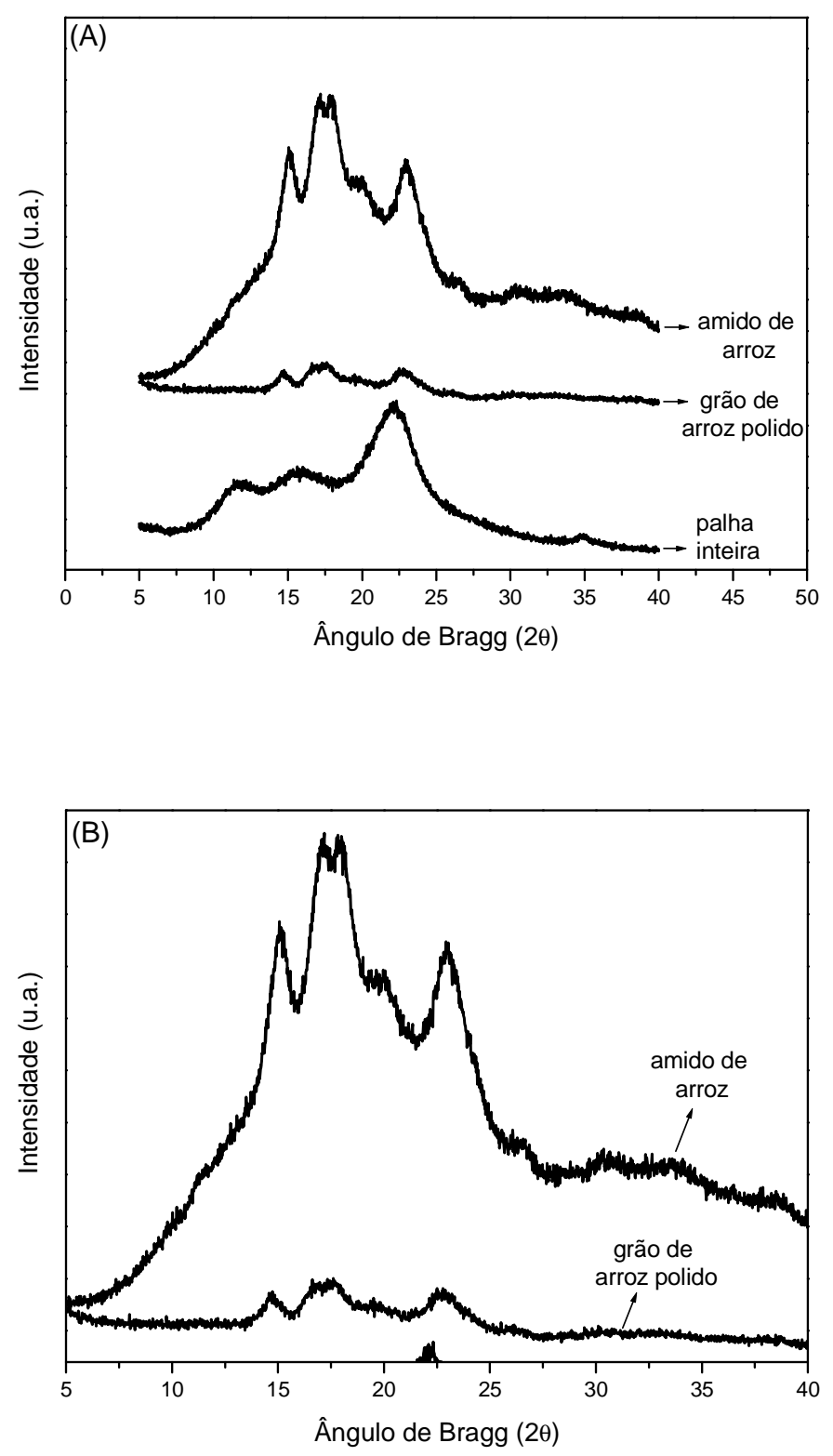

Tanto para o amido de arroz quanto para o arroz em grão observa-se picos cristalográficos em $2 \theta \sim 15^{\circ}, 17^{\circ}, 18^{\circ}$ e 23ำ, característicos do tipo cristalino A, típico de cereais. Porém, o grão de arroz apresenta pequena intensidade de difração. $O$ grau de cristalinidade obtido para o amido de arroz foi $38 \%$, o que corresponde com os valores apontados pela literatura (40\%) (MESTRES, 2006; CEREDA, 2002). O grau de cristalinidade obtido para o grão de arroz polido foi $30 \%$. O difratograma da palha de arroz apresenta picos em $2 \theta \sim 11,6^{\circ}, 15,8$ e entre 22,3ํㅜ, característicos da celulose (FENGEL, 1984). 


\subsubsection{Estabilidade térmica}

O estudo da estabilidade térmica por TG permite identificar a temperatura máxima na qual podemos trabalhar com os materiais poliméricos sem que haja degradação destes. A determinação do comportamento TG dos materiais de partida (amido, quirera, grãos e palha de arroz) possibilita identificarmos qual a temperatura limite a ser empregada durante o processamento dos TPS. A estabilidade térmica dos materiais de partida estudada por TG está representada na figura 4.1.6.

Figura 4.1.6 - Curvas TG e DTG para o amido, quirera, grão integral e palha de arroz.

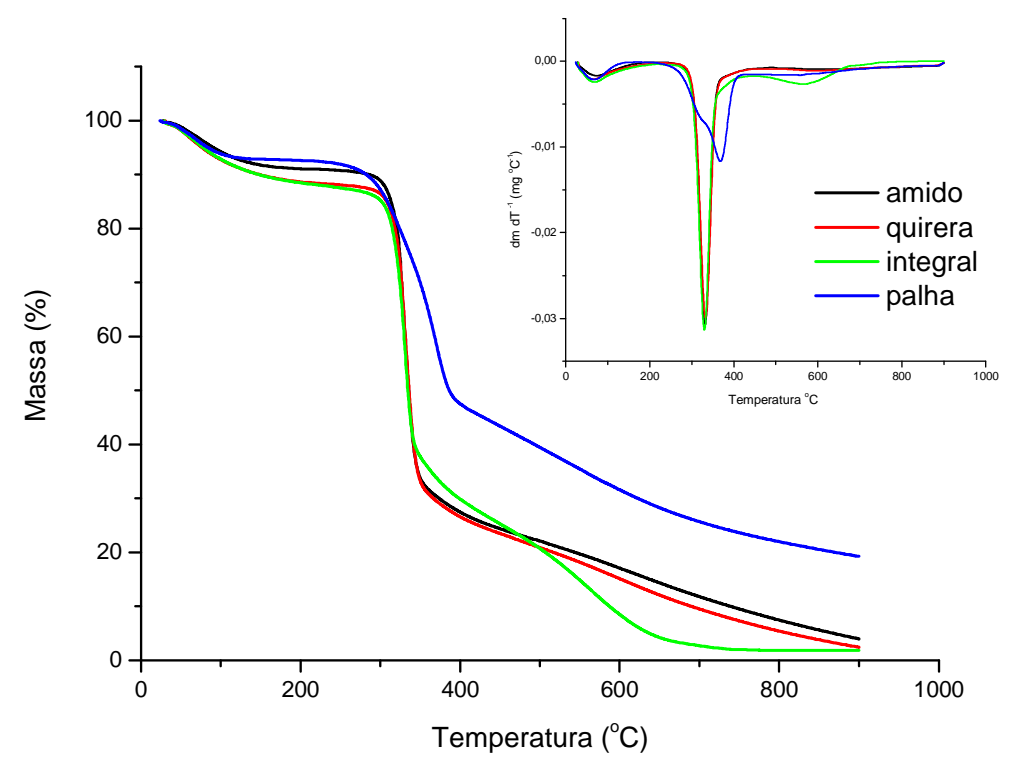

A primeira etapa de perda de massa para as amostras de amido, quirera e grão de arroz integral se localiza entre a temperatura ambiente e $100^{\circ} \mathrm{C}$ e refere-se à saída de água destes materiais.

Para as amostras de amido, grão integral e quirera de arroz, a segunda etapa de perda de massa corresponde à etapa máxima de perda de massa, com degradação do amido. Nesta etapa há eliminação de grupos polihidroxílicos, decomposição e despolimerização das cadeias poliméricas do amido (AGGARWAL; DOLLIMORE, 1999). A temperatura de início da degradação para o amido, quirera e grão integral está em torno de $270^{\circ} \mathrm{C}$ e a temperatura de pico observada no gráfico de DTG está em $325^{\circ} \mathrm{C}$, o que mostra que as três amostras possuem estabilidade térmica semelhante. Nota-se uma terceira etapa de perda de massa em 
temperaturas acima de $400^{\circ} \mathrm{C}$. Esta última etapa está associada com a degradação mais complexa de resíduos carbonáceos (AGGARWAL; DOLLIMORE, 1999; GUINESI et al., 2006) e é mais gradual para a quirera e para o amido.

Para a palha de arroz, a primeira etapa de perda de massa é observada da temperatura ambiente até cerca de $140^{\circ} \mathrm{C}$ e está relacionada a evaporação de água. A segunda etapa de perda de massa vai de 230 a $430^{\circ} \mathrm{C}$. Esta etapa está associada com a decomposição sobreposta dos três principais constituintes da palha de arroz: celulose, hemiceluloses e lignina (KIM et al.,2004; FÁVARO et al., 2006). Segundo Kim e colaboradores (2004), em seu estudo sobre a estabilidade térmica da palha de arroz, a decomposição térmica das hemiceluloses ocorre entre 150 e $350^{\circ} \mathrm{C}$, da celulose entre 275 e $350^{\circ} \mathrm{C}$ e da lignina entre 250 e $500^{\circ} \mathrm{C}$ (KIM et al., 2004). Em temperaturas mais elevadas nota-se um alto teor de material residual (cerca de $20 \%$ de massa). Esse material residual é composto principalmente por sílica (aproximadamente 96\%) (KIM et al., 2004).

\subsubsection{Teor de umidade}

Os teores de umidade dos materiais de partida estão apresentados na tabela 4.1.1. Palha I refere-se à palha apenas lavada; Palha $C$ refere-se à palha imersa em água por 24h, seguido de aquecimento e desfibrilamento; Palha $\mathrm{M}$ refere-se à palha moída em moinho de facas; Palha $\mathrm{P}$ refere-se à palha submetida ao processo de polpação etanol/água $\left(180^{\circ} \mathrm{C}, 105 \mathrm{~min}\right)$.

Tabela 4.1.1 - Teores de umidade dos materiais de partida (continua)

\begin{tabular}{cc}
\hline Amostra & Teor de umidade (\%) \\
\hline Amido & 7,4 \\
\hline Quirera & 12,5 \\
Grão polido & 14,0 \\
Grão integral & 10,2 \\
\hline Palha I & 11,3
\end{tabular}


Tabela 4.1.1 - Teores de umidade dos materiais de partida (continuação)

Amostra

Palha C

Palha M

Palha P
Teor de umidade (\%)

10,1

67,5

\subsubsection{Teor de amilose do amido de arroz}

O teor de amilose pode ser determinado a partir da variação de entalpia envolvida na formação de complexo entre amilose e a enzina LPC. A variação de entalpia é proporcional à área correspondente observada na curva de DSC durante a segunda etapa de resfriamento (MESTRES et al., 1996). A figura 4.1 .7 apresenta a curva de DSC, na qual se verifica a entalpia de formação do complexo entre a amilose e a LPC. O teor de amilose foi determinado pela razão $\Delta \mathrm{H}_{\text {amostral }} / \Delta \mathrm{H}_{\text {padrão }}$ e 0 $\Delta \mathrm{H}_{\text {padrão }}$ adotado foi $25 \mathrm{~J} \mathrm{~g}^{-1}$ (GÉRARD et al., 2001).

Figura 4.1.7 - Curvas DSC para determinação do teor de amilose do amido de arroz.

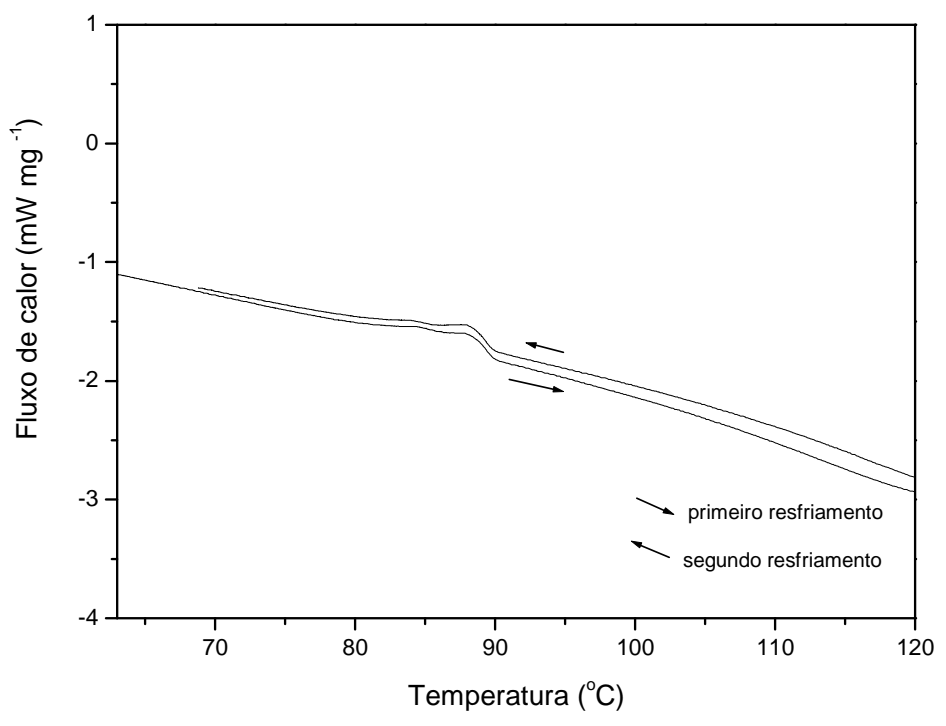

O teor de amilose obtido para o amido de arroz foi 20,96\%. A literatura relata que o arroz é a fonte de amido que apresenta maior variação do teor de amilose, 
com valores que variam entre 8 e 30\% (MESTRES, 1996; CEREDA, 2002). Guinesi e colaboradores (2006) obtiveram os valores de 15, 28, 15 e 14\% de amilose para 0 amido de arroz, milho, batata e mandioca, respectivamente (GUINESI et al., 2006).

\subsubsection{Distribuição da massa molar}

Através da técnica de cromatografia por exclusão de tamanho pode-se avaliar o perfil da distribuição de massa molar da amilose e amilopectina presentes no amido de arroz. A figura 4.1.8 mostra o cromatograma obtido.

Figura 4.1.8 - Cromatograma de HPSEC para amido de arroz.

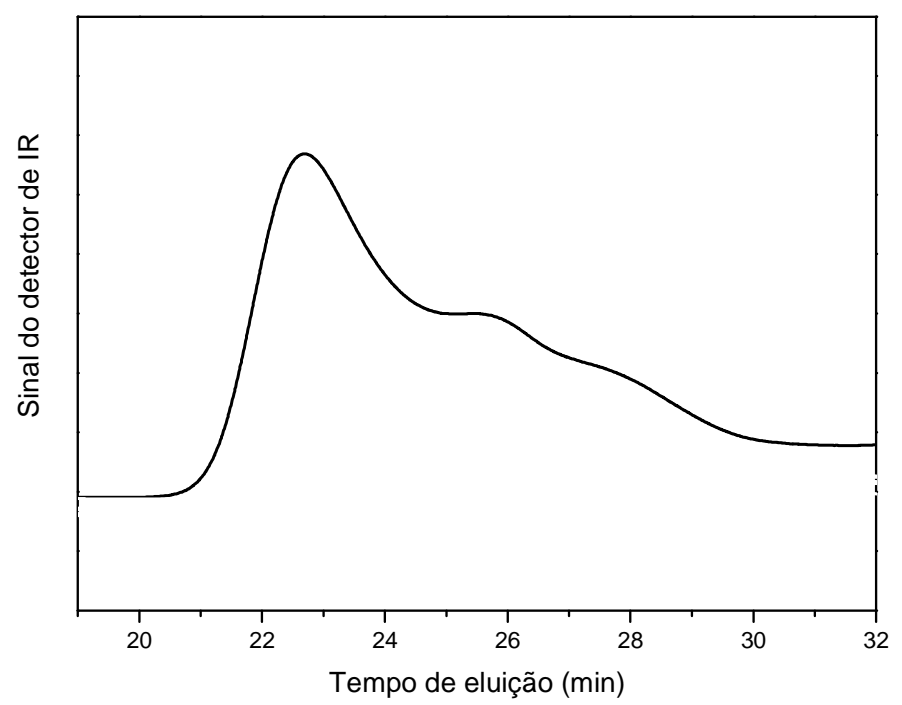

A figura 4.1.8 demonstra que não foi obtido o cromatograma bimodal típico das amostras de amido. Era esperado um cromatograma com perfil bimodal, correspondente a eluição da amilopectina e da amilose. No entanto, para o amido de arroz foi observado uma terceira região, de massa molar e tempo de eluição intermediários ( 26 minutos). Essa região pode ser atribuída à constituintes do amido de arroz que não são separados durante o processo industrial de obtenção do grão, tais como lipídeos e proteínas ou a produtos de fragmentação de amilopectina.

Conforme esperado, o pico correspondente a amilopectina, de maior massa molar, apresentou menor tempo de eluição ( 22 minutos). O pico correspondente a amilose, menor massa molar, apresentou maior tempo de eluição ( 28 minutos). Carvalho et al. (2003) e Teixeira (2007) obtiveram tempos de eluição de 22 e 28 
minutos para amilopectina e amilose para o amido de milho e mandioca, respectivamente (CARVALHO et al., 2003; TEIXEIRA, 2007).

\subsubsection{Conclusões parciais}

O amido de arroz utilizado como material de partida para o presente estudo apresentou propriedades semelhantes às encontradas na literatura para esta fonte de amido.

Os grãos de arroz possuem cristalinidade e estabilidade térmica similares às do amido em grânulo.

O processo de polpação da palha foi o que proporcionou maior liberação de fibras. A palha apresentou cristalinidade e estabilidade térmica características de seus constituintes.

Enfim, a caracterização dos materiais de partida é uma importante etapa para conhecer os materiais de origem e assim identificar a sua influência nas propriedades dos TPS e escolher as melhores condições para a preparação dos compósitos. 


\subsection{Estudo das condições de processamento}

Este estudo foi conduzido com a finalidade de avaliar a influência da temperatura e do tempo no processo de desestruturação dos grânulos de amido para preparação de termoplásticos. Para tal, duas sequências de amostras foram observadas, uma mantendo-se a temperatura fixa e variando-se o tempo; outra mantendo-se o tempo máximo de processamento fixo e variando-se a temperatura. A rotação foi mantida em $60 \mathrm{rpm}$ para ambas sequências. As amostras, constituídas de amido de arroz e glicerol, tiveram o teor de plasticizante fixado em $30 \%$. As temperaturas e tempos estudados foram:

Sequência 1: temperatura fixa em $120^{\circ} \mathrm{C}$, variação do tempo em 4, 6, 8, 10 e 12 minutos;

Sequência 2: tempo fixo em 8 minutos, variação da temperatura em 100, 110, 120,130 e $140^{\circ} \mathrm{C}$.

\subsubsection{Avaliação dos materiais a partir da reometria de torque}

A partir da reometria de torque podemos verificar o torque necessário para fundir, misturar e homogeneizar uma amostra de material polimérico. O reômetro de torque é um equipamento que utiliza geometrias mais complexa, mas que reproduzem em menor escala as geometrias dos equipamentos convencionais utilizados industrialmente, como misturadores e extrusoras (BRETAS; D'AVILA, 2000).

Uma curva típica obtida em um reômetro de torque, torque versus tempo, apresenta dois picos, conforme demonstra a figura 4.2.1. O primeiro refere-se ao carregamento ou compactação do material. $O$ segundo pico indica $o$ torque necessário para fundir o polímero. Após a fusão, o polímero tende a se homogeneizar e o torque se estabiliza.Teoricamente, esta seria a viscosidade de trabalho do material, o ponto no qual ele deveria ser extrudado ou injetado. Após essas transições, a queda do torque pode sinalizar degradação do material, e o aumento do torque pode caracterizar formação de ligações cruzadas (BRETAS; D'AVILA, 2000). 
Figura 4.2.1 - Curva obtida em um reômetro de torque.

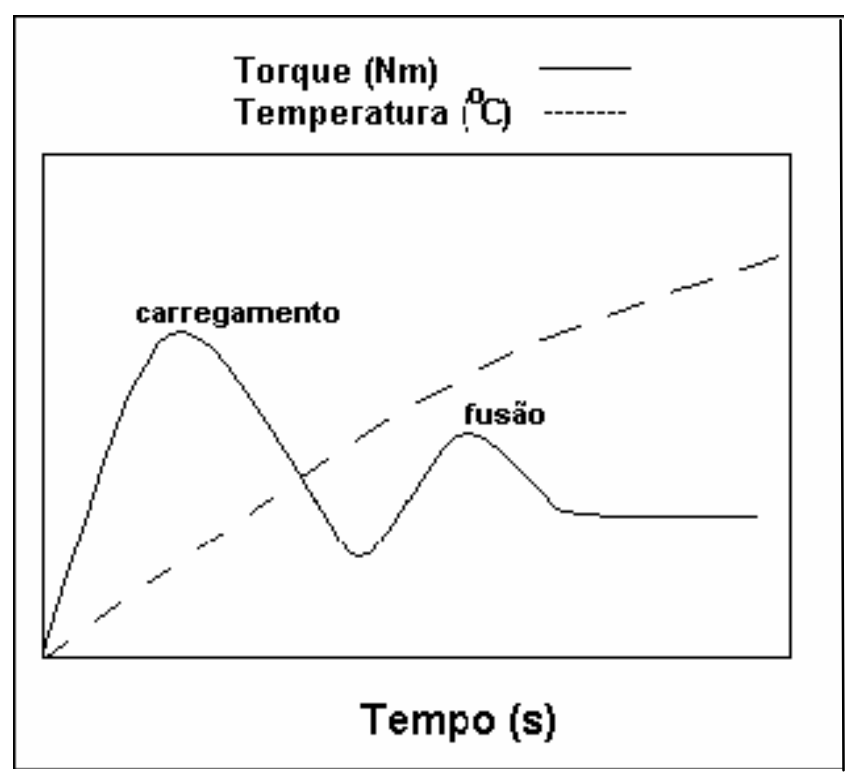

Fonte: BRETAS; D'AVILA, 2000

A figura 4.2.2 apresenta as curvas de torque versus tempo para os ensaios realizados com o tempo máximo fixado em 8 minutos e com a variação de temperatura de processamento entre 100 e $140{ }^{\circ} \mathrm{C}$.

Figura 4.2.2 - Curvas de torque versus tempo para processamento com tempo máximo fixado em 8 minutos e com variação de temperatura.

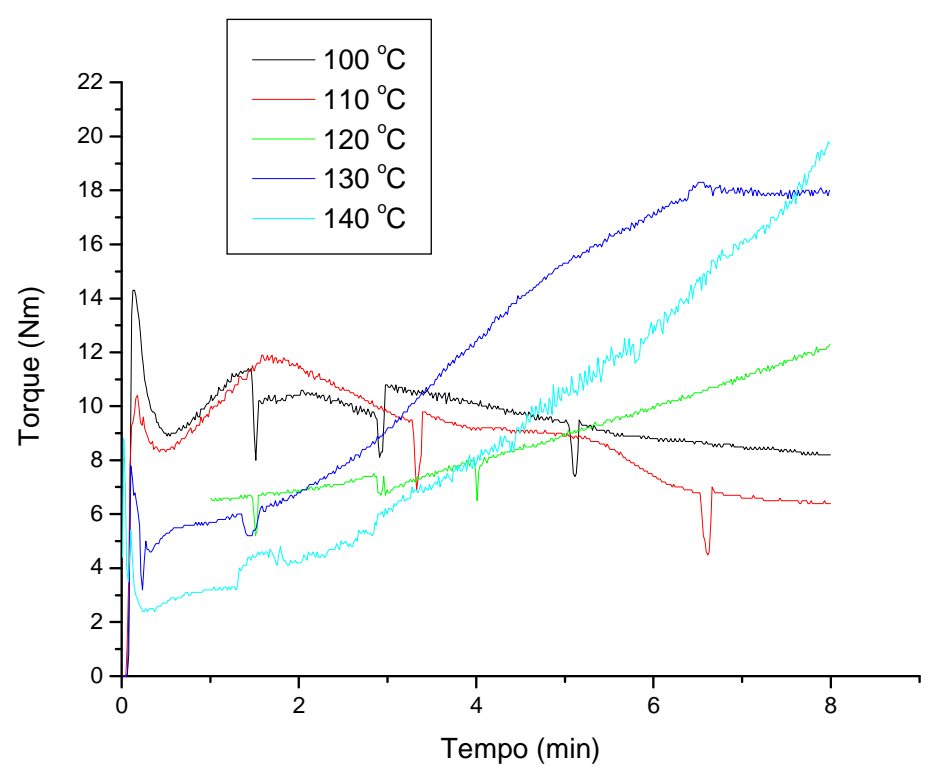

Observa-se na figura 4.2.2 a presença de duas regiões. A primeira está relacionada com o carregamento da amostra e vai de 0 até $0,5 \mathrm{~min}$. O torque 
máximo obtido nesta região, com valor de $14,3 \mathrm{Nm}$, é da amostra processada em $100^{\circ} \mathrm{C}$.

A segunda região, relativa à fusão da amostra, apresentou aspecto diferenciado para as diversas temperaturas. Para temperaturas de processamento iguais ou superiores a $120^{\circ} \mathrm{C}$, não se observa o pico completo, apenas a curva ascendente, o que pode indicar fusão e homogeneização incompleta do polímero. Para estas mesmas temperaturas, no intervalo entre 4 a 7,5 minutos nota-se que 0 valor do torque é maior para temperaturas mais elevadas. A partir de 6,8 minutos observa-se que o torque obtido para amostra processada em $130^{\circ} \mathrm{C}$ se estabiliza em torno de $18 \mathrm{Nm}$. Para as amostras processadas em 100 e $110^{\circ} \mathrm{C}$ observa-se o segundo pico entre 0,5 e 6 minutos e $o$ início da estabilização do torque a partir deste ponto, o que sinaliza fusão e homogeneização mais completa que em outras temperaturas.

A figura 4.2.3 apresenta as curvas de torque versus tempo obtidas a partir da fixação da temperatura de processamento em $120^{\circ} \mathrm{C}$, com a variação do tempo máximo de processamento em 4, 6, 8, 10 e 12 minutos.

Figura 4.2.3 - Curvas de torque versus tempo para amostras processadas em temperatura fixada em $120^{\circ} \mathrm{C}$ e com variação do tempo máximo de processamento.

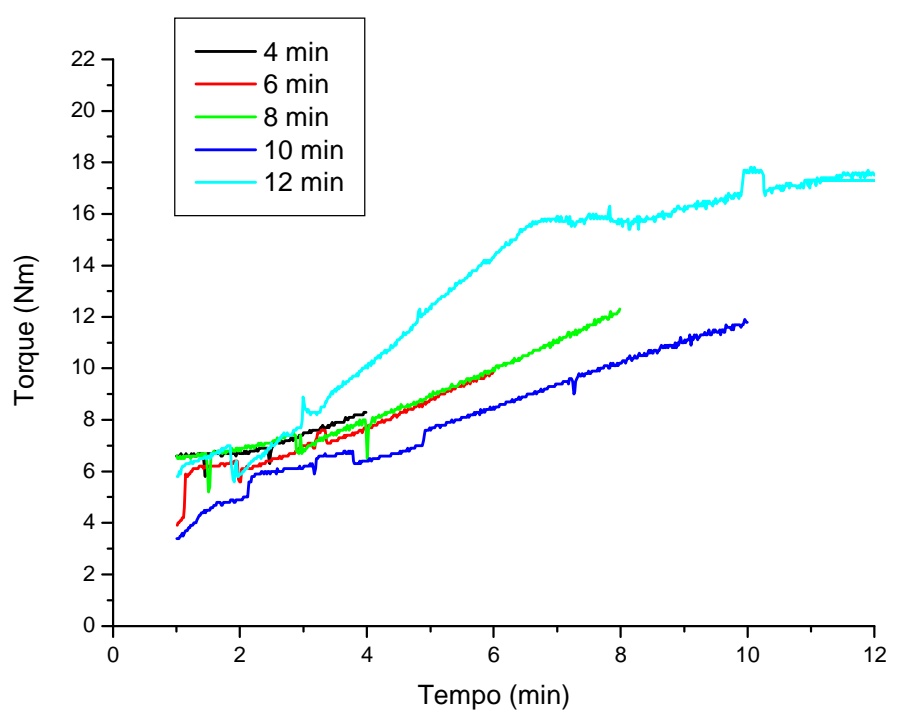

Pelos dados fornecidos pelo equipamento não foi possível identificar o pico de carregamento da amostra, que, conforme observado nas curvas da figura 4.2.2, ocorre entre 0 e 0,5 minuto. Para todos os tempos máximos de processamento observou-se apenas a curva de ascensão e não o pico completo de fusão da 
amostra. O torque observado para as amostras processadas em 4, 6 e 8 minutos apresentou valores similares. Já a amostra processada em 12 minutos apresentou maior torque em função do tempo que as demais amostras. A amostra processada em 10 minutos apresentou menor torque em função do tempo que as demais amostras.

\subsubsection{Avaliação estrutural por difração de raios-X}

O perfil cristalográfico das amostras após o processamento no reômetro de torque pode ser visto na figura 4.2.4.

Figura 4.2.4 - Perfil cristalográfico das amostras processadas (A) em tempo máximo fixado em 8 minutos, (B) em temperatura de processamento fixada em $120^{\circ} \mathrm{C}$.
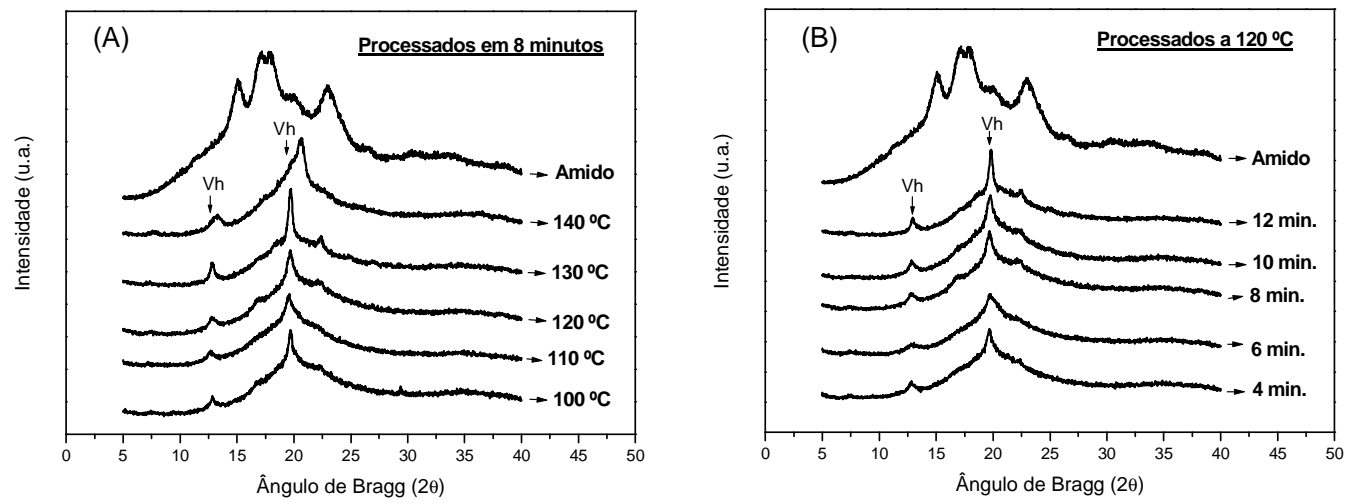

O perfil cristalográfico apresentado na 4.2.4 mostra que todas as condições de processamento, com temperaturas e tempos variados, possibilitaram a desestruturação do grânulo de amido uma vez que a estrutura cristalina característica do amido de arroz (padrão tipo-A) foi rompida, dando lugar para a cristalinidade característica dos amidos termoplásticos (cristalinidade do tipo-V, referente à recristalização da amilose com agentes como lipídeos e polióis, formando hélices simples).

Para a amostra processada em $120^{\circ} \mathrm{C}, 8$ minutos, observa-se um ligeiro pico em $2 \theta \sim 17^{\circ}$. Este pico é característico de cristalinidade residual e é classificado como tipo-B.

A amostra processada em $140^{\circ} \mathrm{C}, 8$ minutos, apresentou seu pico de maior intensidade ligeiramente deslocado para $2 \theta=20,6^{\circ}$. Este valor de $2 \theta$ corresponde a 
forma anidra do complexo tipo-V (Va). As demais amostras apresentam o complexo tipo-V na sua forma hidratada $(\mathrm{Vh}, 2 \theta=19,6)$.

Os índices de cristalinidade do tipo-V (Va para amostra processada em 140 ${ }^{\circ} \mathrm{C}$ e 8 minutos; Vh para as demais) estão ilustrados na figura 4.2.5.

Figura 4.2.5 - Índice de cristalinidade do tipo $\mathrm{V}$ para amostras processadas em tempo máximo de 8 minutos, com variação da temperatura $(A)$; com temperatura fixada em $120^{\circ} \mathrm{C}$, com variação do tempo máximo de processamento (B).

(A)

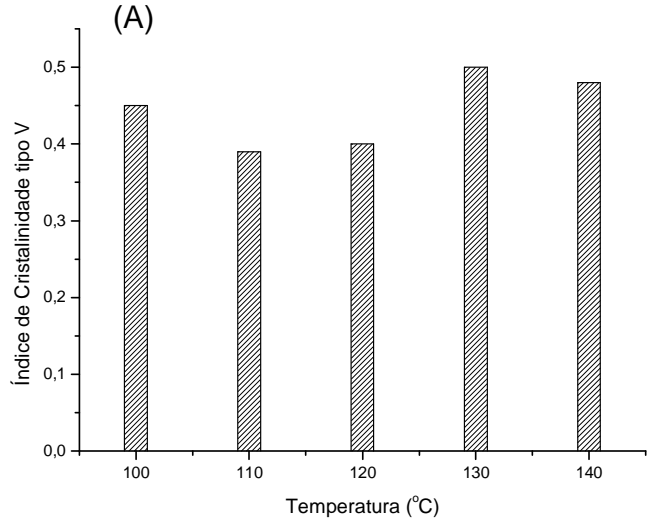

(B)

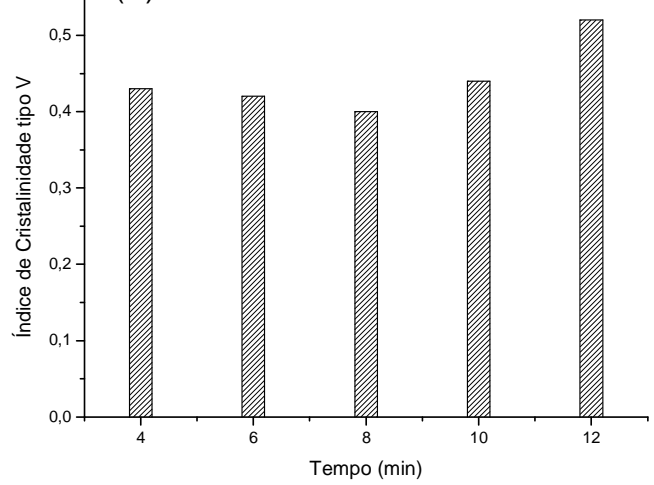

Nota-se que os índices de cristalinidade tipo-V são maiores para amostras processadas em temperaturas e tempos mais elevados $\left(8 \mathrm{~min}, 130\right.$ e $140{ }^{\circ} \mathrm{C} ; 120{ }^{\circ} \mathrm{C}$ 10 e $12 \mathrm{~min})$.

\subsubsection{Análise da morfologia por Microscopia Eletrônica de Varredura (MEV)}

A extensão da desestruturação dos grânulos de amido sob determinadas condições de processamento pode ser avaliada a partir do estudo da morfologia por MEV. A obtenção de superfícies mais homogêneas indica uma melhor processabilidade do material, ao passo que a evidência de aglomerados de amido não desestruturado ou superfície rugosa indicam que as condições préestabelecidas não foram adequadas.

As micrografias de MEV para amostras processadas com o tempo máximo fixado em 8 minutos estão apresentadas na figura 4.2.6. 
Figura 4.2.6 - Micrografias de MEV para amostras processadas em tempo máximo de 8 minutos e temperatura em (A) $100^{\circ} \mathrm{C}$, (B) $110^{\circ} \mathrm{C}$, (C) $120^{\circ} \mathrm{C}$, (D) $130^{\circ} \mathrm{C}$ e (E) $140^{\circ} \mathrm{C}$; com aumento de $500 \mathrm{x}$.
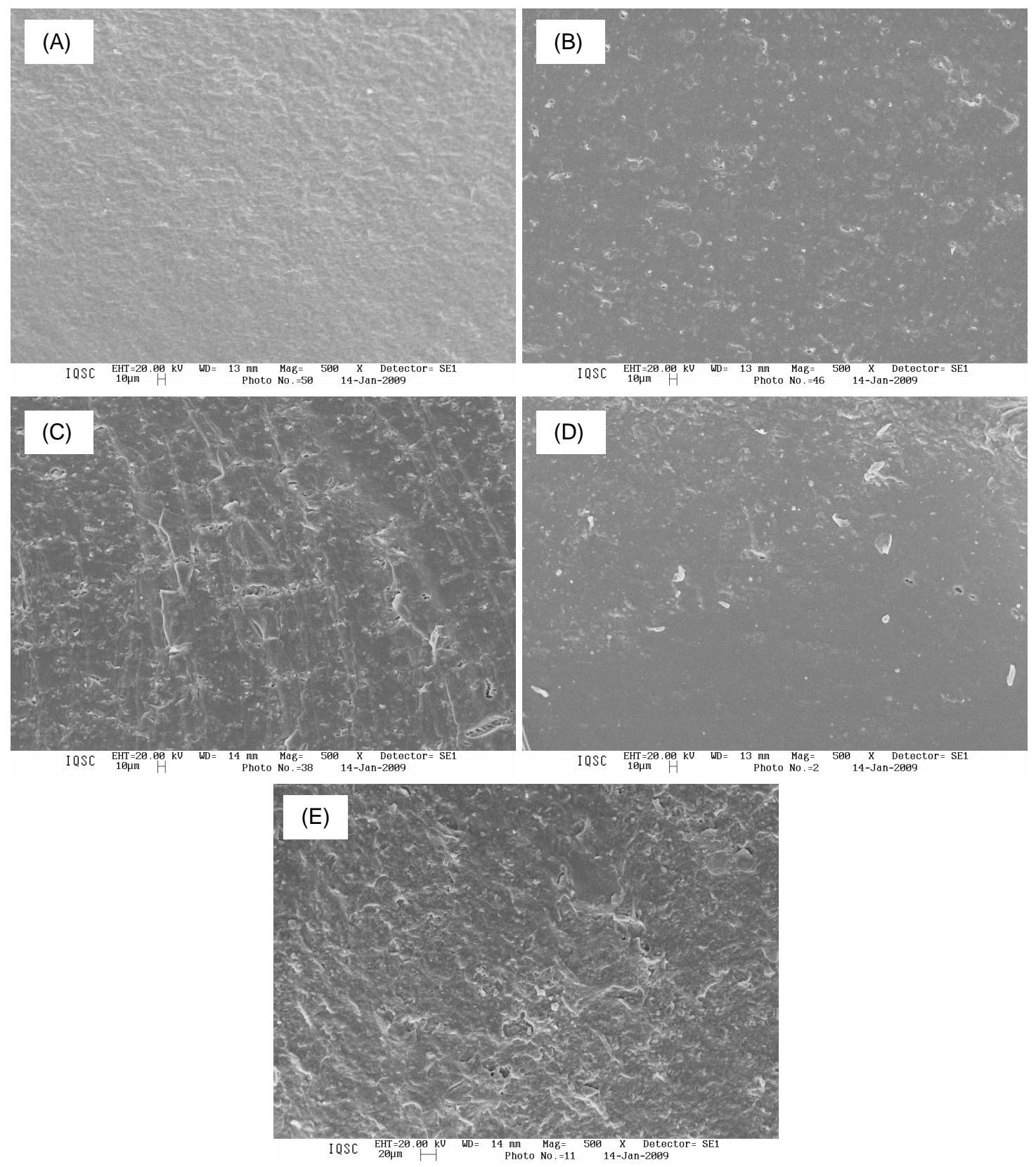

Observa-se alguns pontos dispersos nas superfícies das amostras processadas em $100,110,120,130$ e $140^{\circ} \mathrm{C}$ com a mesma dimensão do grânulo de amido de arroz (de 2 a $11 \mu \mathrm{m}$ ), sinalizando a não completa desestruturação destes. A amostra processada em $130^{\circ} \mathrm{C}$ é a que apresenta menor quantidade de grânulos não desestruturados. As amostras processadas em 100 e $140^{\circ} \mathrm{C}$ são as que apresentaram superfícies mais rugosas se comparadas com as outras amostras 
deste mesmo conjunto. Tal aspecto pode ser decorrente da baixa homogeneização durante o processamento.

A figura 4.2.7 mostra as micrografias obtidas para as amostras processadas em temperatura fixada em $120^{\circ} \mathrm{C}$, com variação do tempo de processamento.

Figura 4.2.7 - Micrografias de MEV para amostras processadas em temperatura fixada em $120^{\circ} \mathrm{C} \mathrm{e}$ com variação de tempo em (A) 4 min, (B) 6 min, (C) 8 min, (D) 10 e (E) 12; com aumento de 500x.
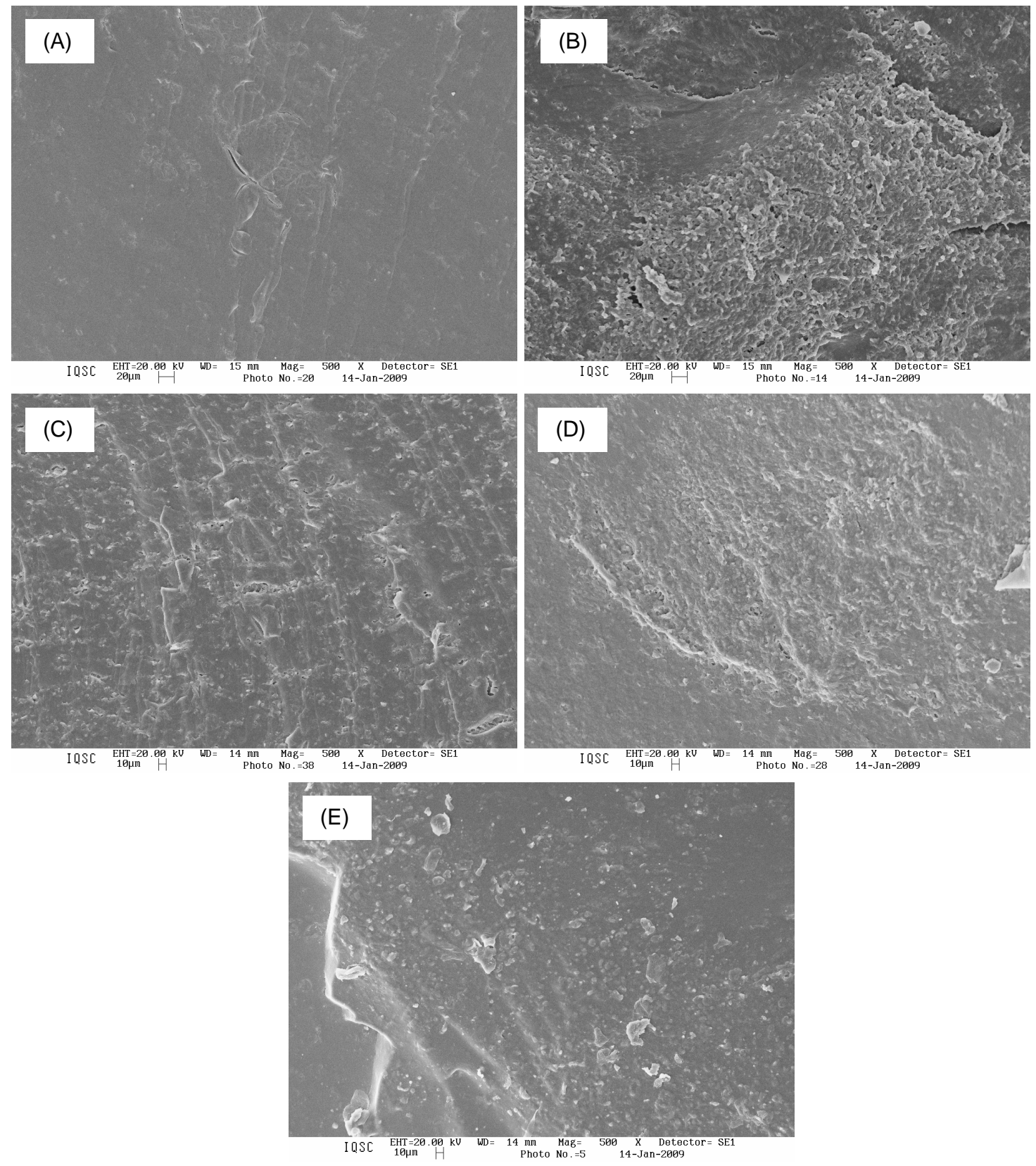

Dentre as micrografias apresentadas na figura 4.2.7, a amostra que apresentou maior homogeneidade foi a processada em 4 minutos. A amostra processada em 6 minutos apresentou grandes regiões de aglomerados de amido 
não desestruturado. A amostra processada em 10 minutos apresentou superfície bastante rugosa e com pontos dispersos de grânulo de amido. As amostras processadas em 8 e 12 minutos apresentaram superfície homogênea, porém com alguns pontos característico de amido não desestruturado.

\subsubsection{Estudo do efeito das condições de processamento na degradação do amido}

O estudo da influência das condições de processamento (tempo e temperatura) na distribuição da massa molecular do amido foi realizado a partir de dados obtidos pela cromatografia por exclusão de tamanho (HPSEC). A figura 4.2.8 apresenta os resultados obtidos tanto para amostras processadas com o tempo máximo fixado em 8 minutos quanto para amostras processadas em temperatura fixada em $120^{\circ} \mathrm{C}$.

Figura 4.2.8 - Cromatogramas de HPSEC para amostras processadas com tempo máximo fixado em 8 minutos e com variação de tempo (A) e com temperatura fixada em 120 oC e com variação de tempo máximo $(\mathrm{B})$.
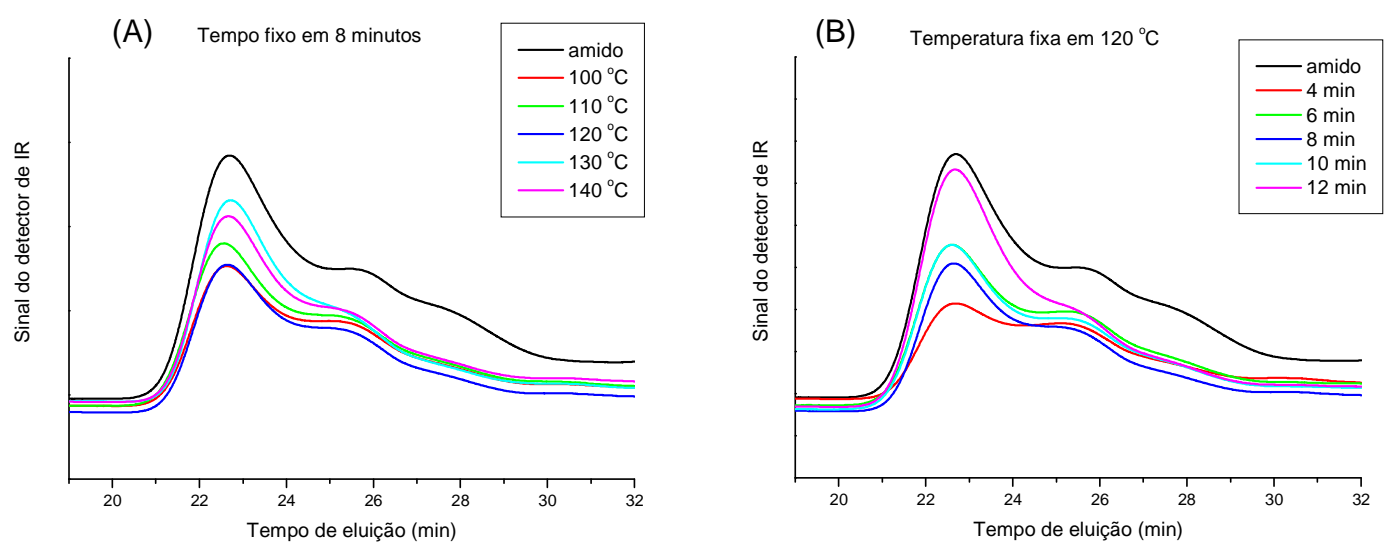

Observa-se para todas as condições de processamento um padrão bimodal. Com o processamento, o pico relativo a massas moleculares menores, com maiores tempos de eluição ( $28 \mathrm{~min}$ ), é bastante afetado e praticamente desaparece. Este pico, conforme descrito na literatura (CARVALHO et al., 2003; TEIXEIRA, 2007), refere-se a amilose. A extensão da degradação da amilose é similar para todas as condições. 
A amilopectina tem sua massa molar pouco afetada pelo processamento (pico com menor tempo de eluição), indepedente das condições de tempo e temperatura.

\subsubsection{Conclusões parciais}

A partir do estudo das condições de processamento, pode-se concluir que a utilização de apenas uma técnica é insuficiente para determinação das condições de processamento que melhor contribuem para desestruturação do grânulo, mistura e homogeneização do TPS. As melhores condições indicadas por uma técnica não são necessariamente as mesmas que as indicadas por outras técnicas. Assim, o uso combinado de técnicas é mais apropriado para a escolha das condições de processamento que melhor se adequam a determinada amostra.

Segundo os resultados apontados pela reometria de torque, as amostras processadas em 100 e $110^{\circ} \mathrm{C}, 8$ minutos foram as que apresentaram fusão e homogeneização mais completa durante o processamento.

Pela difração de raios-X observamos que todas as condições de processamento foram capazes de promover a desestruturação dos grânulos de amido.

Avaliando-se a superfície das amostras por MEV, observamos que as condições que possibilitaram superfície mais homogênea foram $130^{\circ} \mathrm{C}, 8$ minutos; $120^{\circ} \mathrm{C}, 4$ minutos; $120^{\circ} \mathrm{C}, 8$ minutos.

Com base nas características dos fundidos em função das variáveis das técnicas empregadas, para o presente trabalho optou-se pelo processamento em $120^{\circ} \mathrm{C}, 8$ minutos e com rotação de $60 \mathrm{rpm}$ para os TPS e compósitos constituídos por amido de arroz/glicerol, amido de arroz/glicerol/palha e grão de arroz/glicerol. Além disso, como a temperatura durante o processamento tem variação de mais ou menos $10^{\circ} \mathrm{C}$, a fixação da temperatura em $120^{\circ} \mathrm{C}$ possibilita com que toda a água (agente de processo) presente nas amostras seja eliminada. 


\subsection{Estudo do efeito da composição amido de arroz / glicerol nas propriedades físico-químicas dos amidos termoplásticos}

Este estudo foi realizado com o intuito de avaliar a influência do material de origem e do conteúdo de plasticizante nas propriedades físico-químicas dos termoplásticos preparados a partir de amido de arroz.

\subsubsection{Estudo morfológico e estrutural}

A morfologia e estrutura dos TPS preparados a partir de amido de arroz foram estudadas por microscopia eletrônica de varredura e por difração de raios-X, respectivamente. Tal estudo visou avaliar a extensão da desestruturação dos grânulos de amido durante o processamento do TPS.

A figura 4.3.1 apresenta a morfologia dos TPS. A amostra com teor de $20 \%$ de plasticizante apresentou superfície homogênea, mas com pontuações dispersas que podem ser grânulos de amido. Apresentou ainda fissuras geradas por fratura frágil e superfície com aspecto vítreo. As composições com 25\%, 30\% e 35\% de glicerol apresentaram superfície mais homogênea, sendo que a composição de $25 \%$ apresentou algumas regiões de estratificação. A homogeneidade da superfície indica que as condições de processamento foram suficientes para promover a completa desestruturação do amido. Para o TPS com teor de 40\% de plasticizante observa-se uma superfície mais rugosa e com nítida presença de grânulos de amido não desestruturados. A desestruturação incompleta pode ser justificada pela baixa viscosidade gerada no sistema de processamento devido ao alto teor de plasticizante, ocasionando uma desestruturação incompleta dos grânulos de amido (TEIXEIRA, 2007). 
Figura 4.3.1 - Micrografias de MEV para os TPS com 20\% (A), $25 \%$ (B), $30 \%$ (C), $35 \%$ (D) e $40 \%$ (E) de plasticizante.
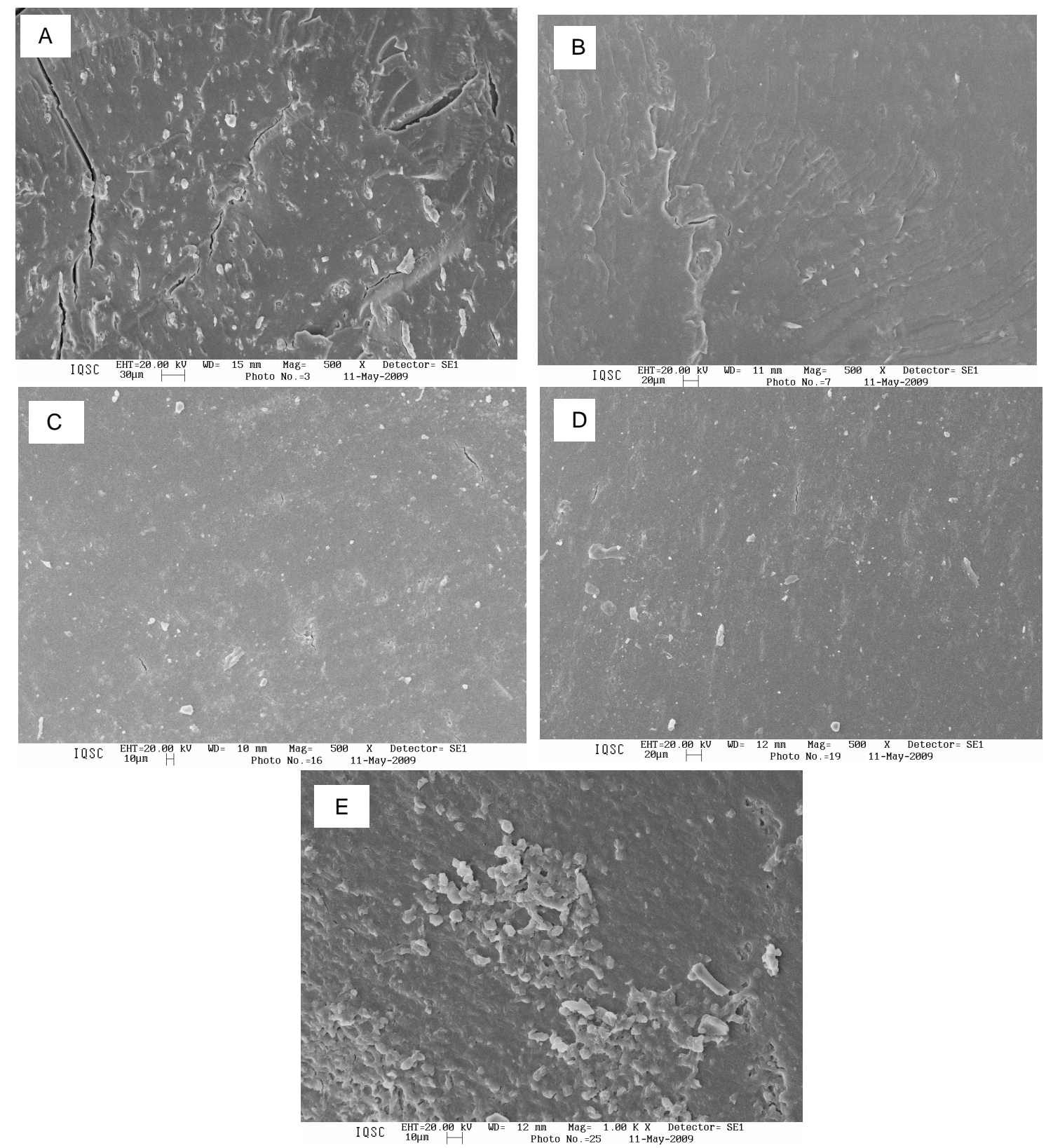

O perfil cristalográfico dos TPS pode ser observado na figura 4.3.2. 
Figura 4.3.2 - Difratograma de raios-X dos TPS amido/glicerol.

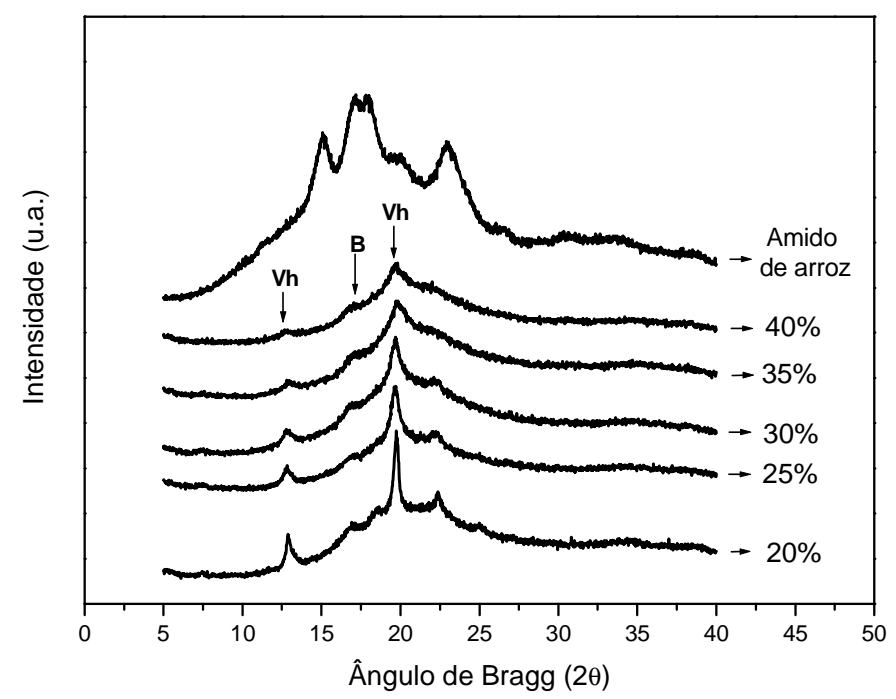

O padrão de cristalinidade tipo $\mathrm{B}\left(2 \theta \sim 17^{\circ}\right)$, referente à cristalinidade residual ou recristalização da amilopectina durante o processamento e estoque, apresenta picos muito pequenos nos difratogramas de raios- $X$. Nota-se picos mais acentuados em $2 \theta \sim 19,6^{\circ}$ e em $2 \theta \sim 13^{\circ}$ referentes ao padrão de cristalinidade tipo $\mathrm{Vh}$, característico da cristalização das estruturas hélice simples da amilose, ausentes no amido granular. Essas características dos difratogramas de raios- $X$ indicam que 0 processamento dos TPS possibilitou a desestruturação dos grânulos de amido.

Os índices de cristalinidade estão representados na figura 4.3.3.

Figura 4.3.3 - Índice de cristalinidade dos TPS amido/glicerol: tipo Vh (A) e tipo B (B).
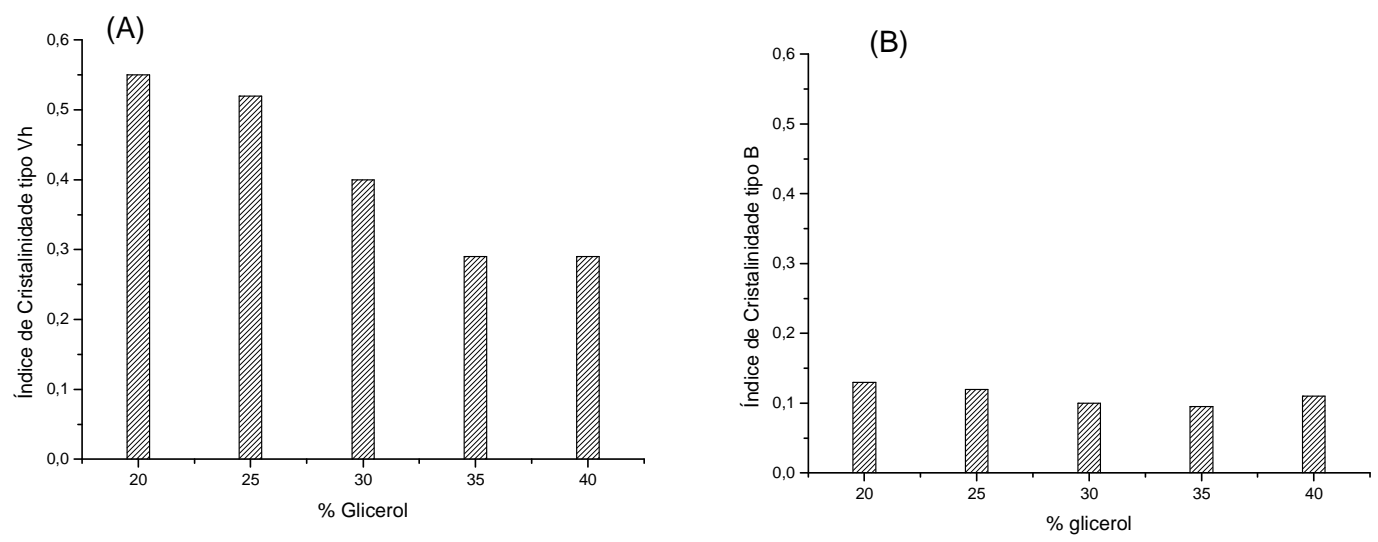

Conforme ilustra a figura 4.3.3, o índice de cristalinidade tipo Vh tende a diminuir com o aumento do conteúdo de plasticizante, já a cristalinidade tipo B 
permanece praticamente inalterada. A diminuição do índice de cristalinidade do tipo Vh com o aumento do teor de glicerol está relacionada com a menor mobilidade das cadeias de amilose nesta condição, impedindo a sua interação com outros constituintes como lipídeos (TEIXEIRA et al., 2005). Conforme relata Carvalho et al. (2003), maiores teores de plasticizante proporcionam menor degradação das cadeias poliméricas do amido durante o processamento do TPS (CARVALHO et al., 2003), podendo gerar menor mobilidade destas.

Levando em consideração estudos de TPS preparados a partir de outras fontes de amido como milho, mandioca e batata (CARVALHO, 2002; TEIXEIRA, 2007; PONTES, 2007), observa-se que o padrão de cristalinidade do tipo $B$ é menor para TPS preparados a partir de amido de arroz. Já os valores do índice de cristalinidade Vh dos TPS de arroz são semelhantes aos dos TPS de mandioca e menores que os dos TPS de milho e batata.

\subsubsection{Capacidade de absorção de água}

Uma das principais limitações dos termoplásticos preparados a partir de amido é a sua alta capacidade de absorção de água. Sendo assim, a quantificação da higroscopicidade tem grande relevância no estudo destes materiais. Os ensaios de absorção de água foram realizados com o objetivo de verificar a estabilidade das amostras de TPS e determinar a capacidade máxima de absorção de água frente à ambientes de diferentes umidades relativas (u.r.) controladas $(22,5 \%, 43 \%, 53 \%$, $75 \%$ e $84 \%)$.

A figura 4.3.4 mostra as curvas da absorção de água em função do tempo para as diversas umidades relativas estudadas. 
Figura 4.3.4 - Curvas de absorção de água (\%) em função do tempo (h) para amostras de TPS condicionadas em ambientes de umidade relativa de $22,5 \%$ (A), $43 \%(B), 53 \%$ (C), $75 \%$ (D) e $84 \%$ (E).
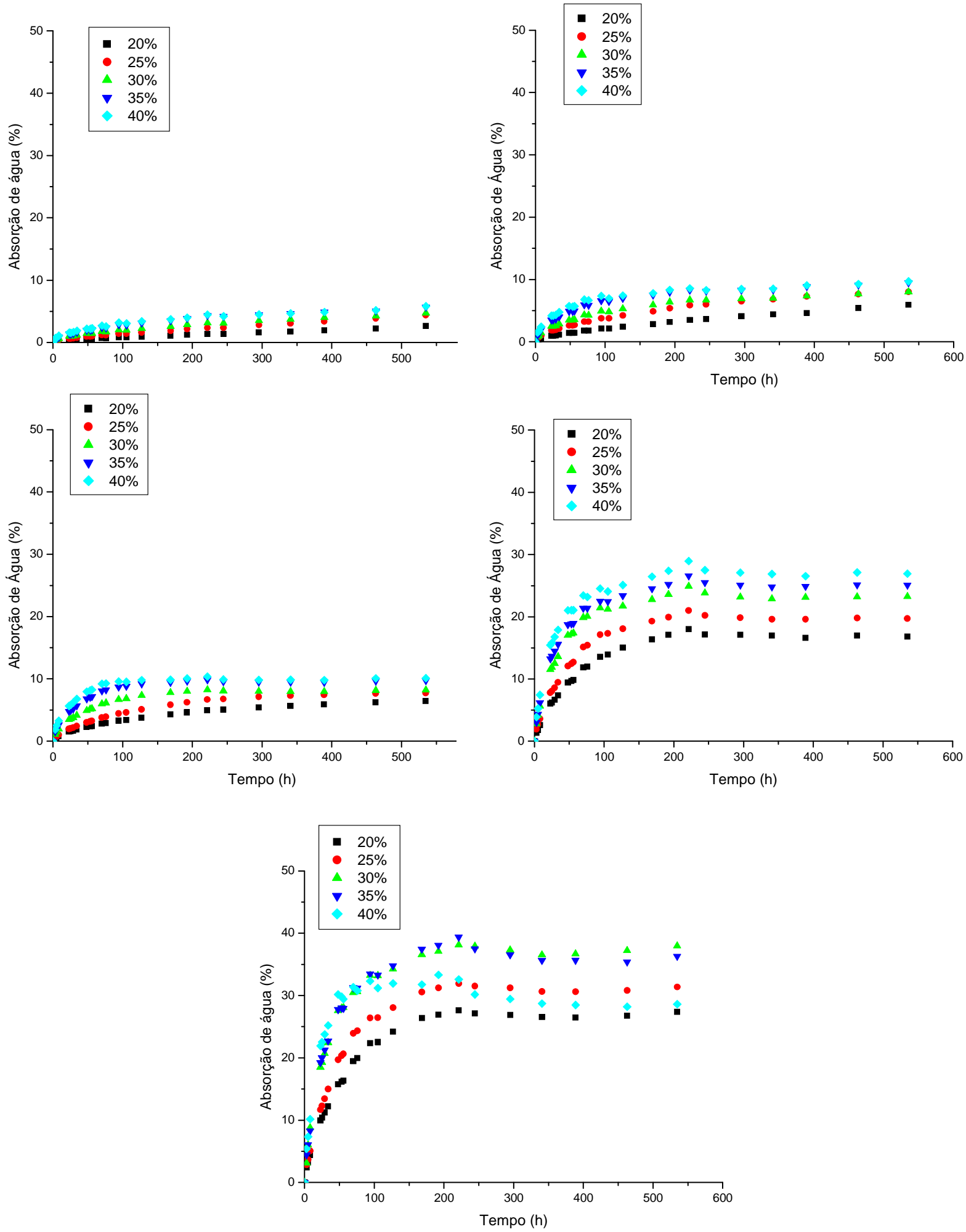

Nota-se que para todas as umidades relativas há um ganho de massa mais rápido até cerca de $110 \mathrm{~h}$. A estabilização da absorção de água se dá em torno de 
200h para amostras condicionadas em ambiente de u.r. igual ou maior que 53\%. Já para amostras condicionadas em 22,5\% e 43\% a estabilização é mais lenta. As amostras condicionadas em ambiente de $84 \%$ de u.r. apresentaram gotículas de água em tempos maiores, sendo necessário enxugá-las com papel absorvente antes da pesagem. O corpo de prova do TPS com 40\% de glicerol condicionado em ambiente de u.r. de $84 \%$ quebrou em torno de $200 \mathrm{~h}$ de condicionamento devido à absorção de água, acarretando em perda de massa.

A figura 4.3.5 apresenta a absorção máxima de água para amostras de TPS amido/glicerol condicionadas nos diversos ambientes de umidade relativa.

Figura 4.3.5 - Absorção máxima de água em função do teor de glicerol para os TPS de amido de arroz.

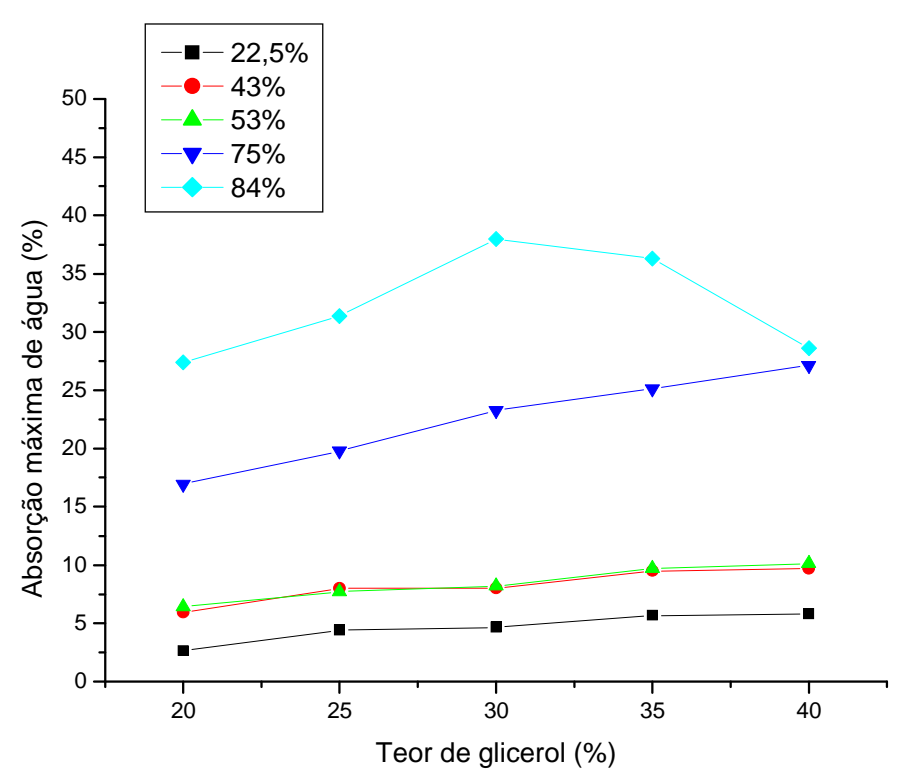

Observa-se que a absorção de água é mais significativa para u.r. de $75 \%$ e $84 \%$. Exceto para u.r. de 84\%, a absorção de água aumenta de maneira praticamente linear com o aumento do teor de plasticizante. Essa tendência de aumento da absorção com o aumento do teor de plasticizante tem sido relatada na literatura (CARVALHO, 2002; TEIXEIRA et al., 2005; DA RÓZ et al., 2006; PONTES, 2007).

Os resultados obtidos para amostras condicionadas em ambiente de umidade relativa de 53\% apontam que os TPS preparados a partir de amido de arroz apresentam menor absorção de água no equilíbrio que os TPS preparados a partir 
de amido de milho, mandioca e batata (CARVALHO, 2002; TEIXIERA, 2007; PONTES, 2007).

\subsubsection{Comportamento mecânico}

Os ensaios mecânicos de tração foram realizados com o intuito de verificar o efeito do teor de glicerol sobre as propriedades mecânicas dos TPS preparados a partir de amido de arroz.

A figura 4.3.6 apresenta as curvas dos ensaios de tração.

Figura 4.3.6 - Curvas de tensão X alongamento para os TPS de amido de arroz plasticizados com diversos teores de glicerol.

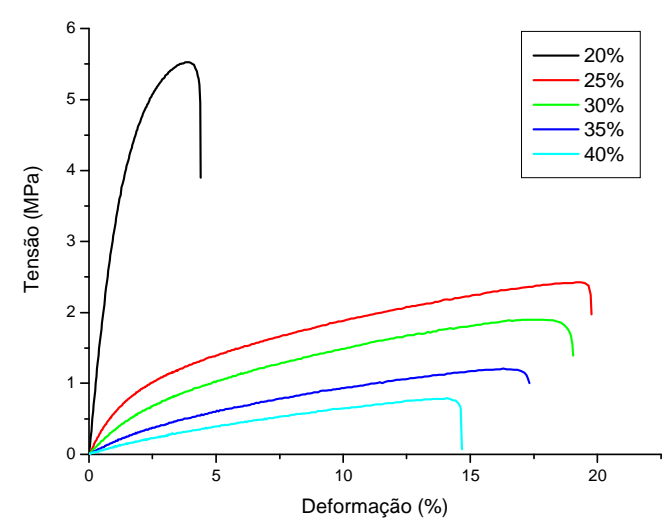

Observa-se que a tensão máxima de ruptura diminui com o aumento do teor de plasticizante, sendo que a diminuição entre 20 e $25 \%$ é abrupta. O alongamento máximo diminui com o aumento do teor de plasticizante para amostras de 25 a 40\% de glicerol. A amostra com $20 \%$ de plasticizante apresenta pouco alongamento antes da ruptura.

A figura 4.3.7 apresenta os valores médios para a tensão máxima, alongamento máximo e módulo elástico. 
Figura 4.3.7 - Comportamento mecânico de tensão máxima na ruptura $(A)$, alongamento máximo $(B)$ e módulo elástico $(\mathrm{C})$.
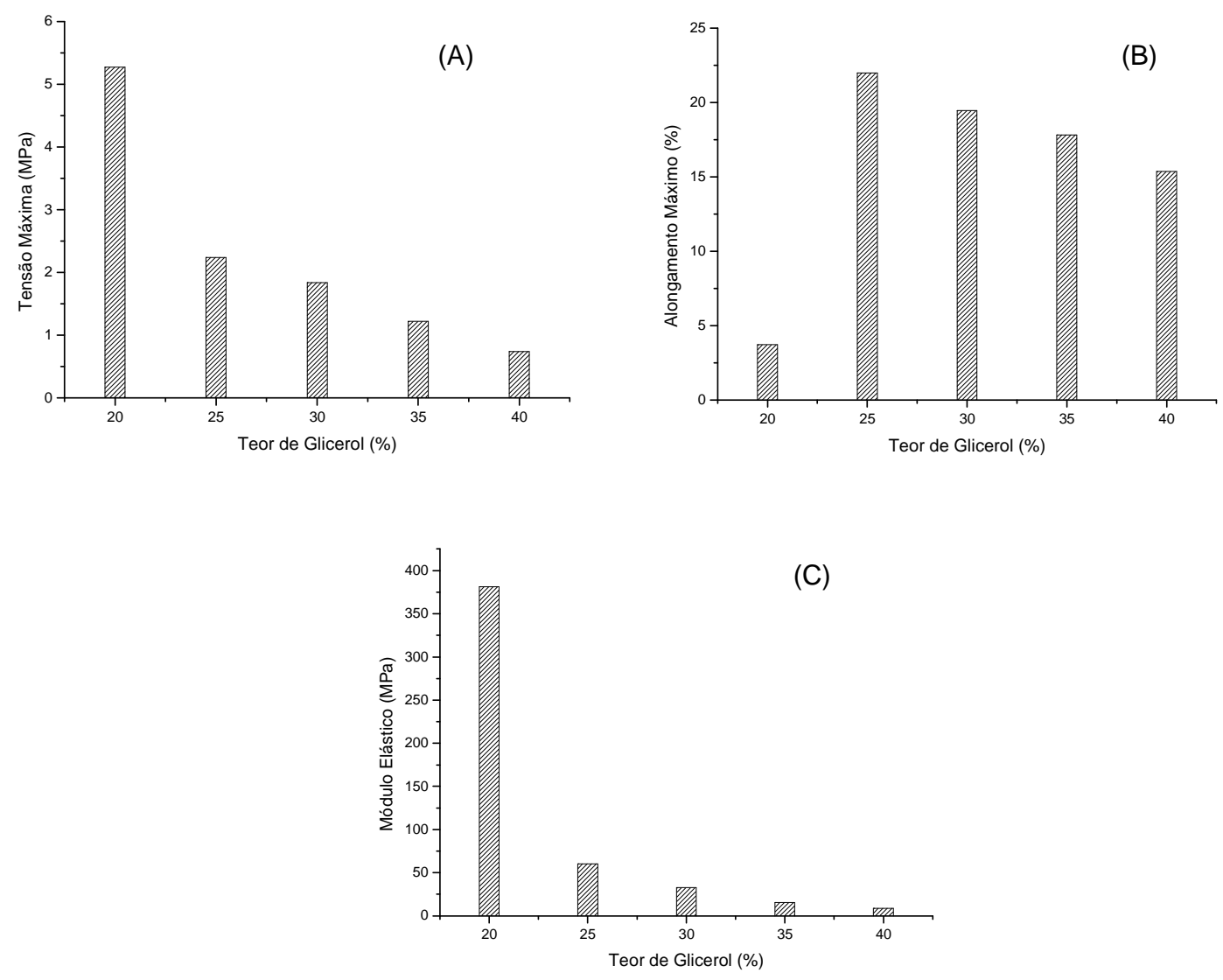

Em relação ao módulo elástico, este diminui com aumento do teor de plasticizante, apresentando uma diminuição abrupta entre 20 e $25 \%$. O caráter diferenciado da amostra com $20 \%$ de glicerol frente às demais pode estar relacionado com o fato do ensaio de tração ter sido realizado abaixo da temperatura de transição vítrea desta, conforme pode ser visto no item 4.3.4, o que proporciona maior rigidez. A diminuição da tensão máxima, do módulo elástico e do alongamento máximo com o aumento do teor de glicerol está relacionada ao fato do agente plasticizante enfraquecer as ligações intermoleculares existentes nos TPS, fazendo com que os materiais se tornem menos resistentes a uma solicitação mecânica. Além disso, a maior absorção de água e menor cristalinidade apresentadas por amostras com maiores teores de plasticizante também influenciam a diminuição da resistência mecânica dos TPS uma vez que cristalitos conferem maior resistência aos materiais (CALLISTER, 2008) e a água atua como agente plasticizante, enfraquecendo ainda mais as ligações entre as cadeias poliméricas. 
Os valores alcançados para tensão máxima e alongamento máximo foram próximos aos encontrados por Teixeira (2007) para TPS preparado a partir de amido de mandioca, mas inferiores aos valores encontrados por Carvalho (2002) e Pontes (2007) para TPS de amido de milho e batata, respectivamente (CARVALHO, 2002; TEIXIERA, 2007; PONTES, 2007).

\subsubsection{Caracterização térmica}

O comportamento térmico foi estudado por Termogravimetria (TG) para avaliar a estabilidade térmica dos TPS; por Calorimetria Diferencial Exploratória (DSC) para determinar a Temperatura de Fusão (Tm) e a Temperatura de Transição Vítrea (Tg) das amostras; e por Análise Térmica-Dinâmico-Mecânica (DMA) para determinação da Tg.

A figura 4.3.8 ilustra os resultados obtidos para estabilidade térmica a partir da técnica de TG para amostras de TPS amido/glicerol.

Figura 4.3.8 - Curvas TG e DTG para TPS de amido/glicerol.

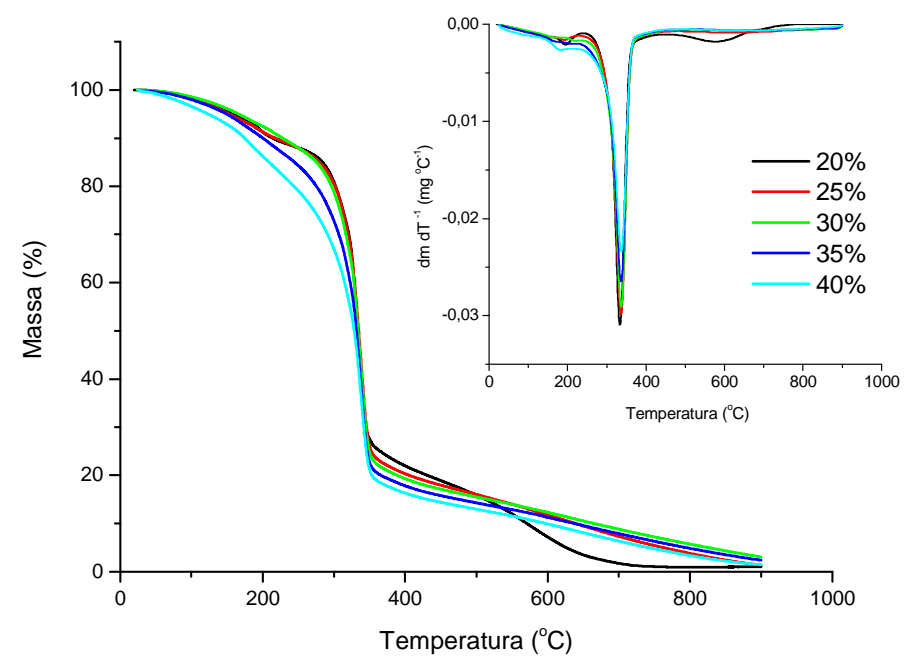

Percebe-se pelas curvas TG e DTG a presença de três eventos térmicos. 0 primeiro, que ocorre entre a temperatura ambiente e $275^{\circ} \mathrm{C}$, está relacionado à perda de água e parte do plasticizante. A perda de massa no primeiro evento é mais acentuada para amostras com maiores teores de plasticizante, o que ratifica a relação deste evento com a perda de glicerol. O segundo evento está associado à 
perda de massa do próprio amido e ocorre entre 275 e $400^{\circ} \mathrm{C}$. Observa-se ainda perda de massa acima de $400^{\circ} \mathrm{C}$. Esta perda a altas temperaturas refere-se à degradação de resíduos carbonáceos. A temperatura de pico observada pela DTG para o principal evento térmico está entre 335 e $336^{\circ} \mathrm{C}$. A estabilidade térmica apresentada pelos TPS é similar a do amido, o que demonstra que o plasticizante pouco interferiu na estabilidade térmica do material de partida.

Os resultados obtidos a partir da técnica de DSC estão apresentados na figura 4.3.9.

Figura 4.3.9 - Curvas de DSC para amostras de TPS amido/glicerol: (A) curva completa, (B) curva entre -50 e $50^{\circ} \mathrm{C}$.
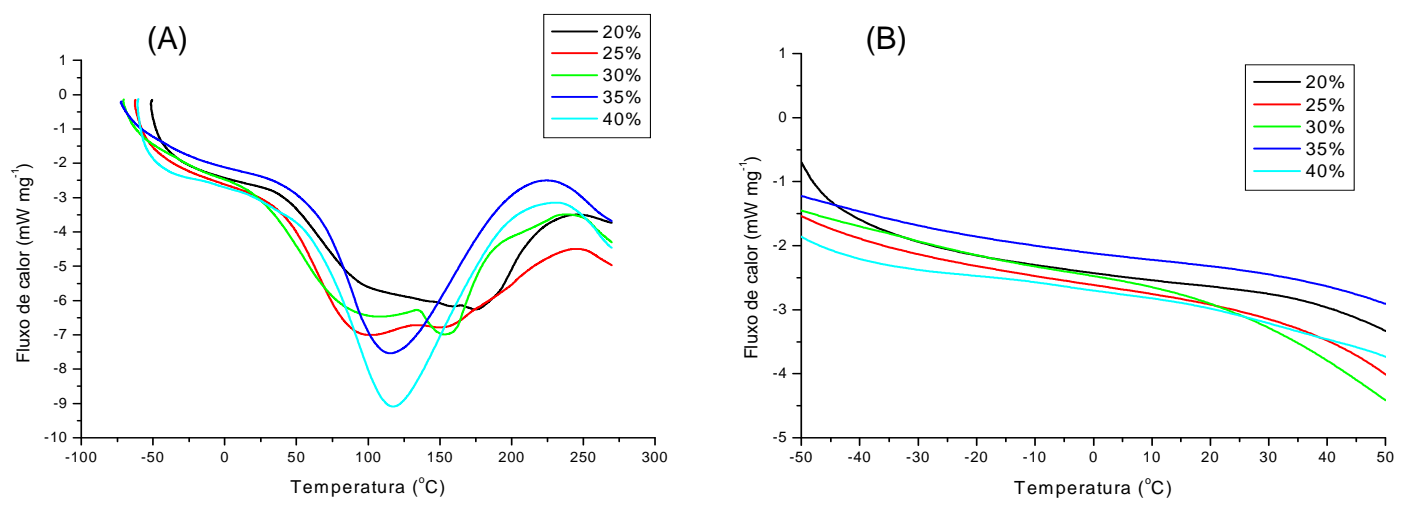

À baixas temperaturas, entre -50 e $50^{\circ} \mathrm{C}$, não foram observados eventos térmicos para as amostras, não sendo possível, portanto, identificar a temperatura de transição vítrea por esta técnica. A transição vítrea para TPS preparados a partir das diversas fontes de amido ocorre normalmente nesta faixa de temperatura.

Para amostras com teores de glicerol entre 35 e 40\% foi observado um pico endotérmico entre 30 e $220^{\circ} \mathrm{C}$ associado a evaporação sobreposta de água e plasticizante. Para menores teores de glicerol, observa-se a existência de dois picos, um na região entre 30 e $140^{\circ} \mathrm{C}$, outro na região entre 140 e $240^{\circ} \mathrm{C}$. Estes picos também estão associados com a saída de água e plasticizante, respectivamente. Porém, diferentemente das amostras com 35 e 40\% de glicerol, a evaporação se dá em intervalos de temperatura distintos e não sobrepostos. Os resultados obtidos a partir de TG (figura 4.3.8) também demonstram que para teores mais baixos de glicerol (entre 20 e 30\%) a água e o glicerol evaporam em faixas de temperaturas 
distintas. Não foi possível identificar a temperatura de fusão a partir das condições estabelecidas para o ensaio de DSC.

Figura 4.3.10 - Curvas da tangente de perda $(\tan \delta)(A)$ e módulo de armazenamento (E') (B) em função da temperatura para os TPS amido/glicerol.
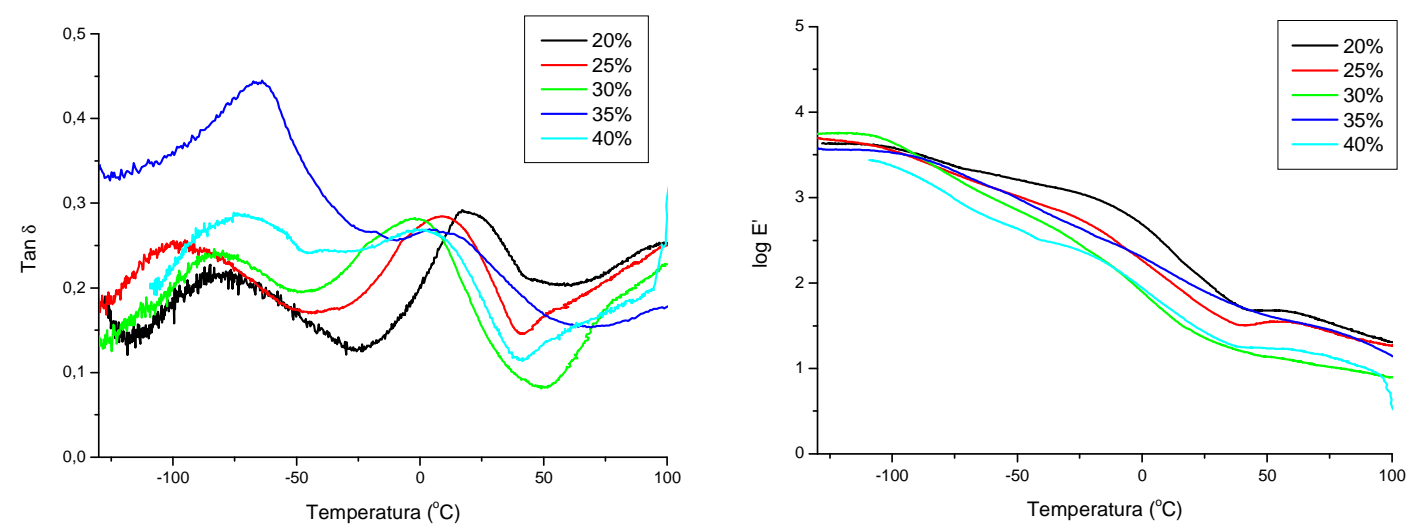

A tabela 4.3.1 mostra a variação da temperatura de transição vítrea em função do teor de glicerol. A Tg foi considerada como a temperatura de máximo do pico da transição que ocorre em temperaturas mais elevadas para os gráficos de Tan $\delta$ versus Temperatura.

Tabela 4.3.1 - Tg em função do teor de glicerol para TPS amido/glicerol.

\begin{tabular}{cc}
\hline Teor de glicerol (\%) & $\operatorname{Tg}\left({ }^{\circ} \mathrm{C}\right)$ \\
\hline 20 & 23,0 \\
25 & 9,4 \\
30 & 2 \\
35 & 3,8 \\
40 & 0,7 \\
\hline
\end{tabular}

Observa-se que, exceto para a amostra com $35 \%$ de glicerol, a $\mathrm{Tg}$ diminui com o aumento do teor de plasticizante. $O$ aumento do teor de glicerol gera menores forças de interação entre as cadeias poliméricas, proporcionando maior mobilidade destas. Com o aumento do teor de glicerol há alargamento do pico. Conforme 
relatado na literatura (LOURDIN; BIZOT; COLLONA, 1997; FORSSEL et al, 1997; MOATES et AL, 2001; AVÉROUS, 2004), observa-se a presença de duas transições, uma relacionada com a fase rica em glicerol e outra com a fase rica em amido, o que mostra que o material é parcialmente miscível.

\subsubsection{Conclusões parciais}

Em geral, pode-se afirmar que os TPS preparados a partir de amido de arroz seguiram a mesma tendência de variação de suas propriedades em função do teor de plasticizante que os TPS preparados a partir de outras fontes de amido.

Levando em consideração TPS preparados a partir de amido de mandioca, milho e batata, observa-se que os TPS preparados a partir de amido de arroz apresentaram a menor absorção de água. Em relação a propriedades como índice de cristalinidade tipo Vh, tensão máxima e alongamento máximo, os TPS de amido de arroz apresentaram valores semelhantes aos TPS de amido de mandioca, mas inferiores aos TPS de amido de milho e batata. 


\subsection{Estudo da influência da incorporação de palha de arroz nas propriedades dos termoplásticos preparados a partir de amido de arroz}

Devido aos altos valores de celulose (de 35 a $40 \%$ ) (FENGEL, 1984) e de sílica (12 a 18\%) (RAMEZANIANPOUR; KHANI; AHMADIBENI, 2009) encontrados na palha de arroz, é esperado que os materiais compósitos preparados a partir de amido de arroz e palha apresentem melhor desempenho mecânico e menor absorção de água, conforme demonstram estudos envolvendo fibras vegetais (CURVELO; CARVALHO; AGNELLI, 2001; AVÉROUS; BOQUILLON, 2004; TAKAGI; ICHIHARA, 2004; TEIXEIRA, 2007) e cargas minerais como materiais de reforço para TPS (CARVALHO; CURVELO; AGNELLI, 2001; YU; DEAN; LI, 2006; TEIXEIRA, 2007). É neste sentido que o presente estudo foi conduzido.

A palha foi tratada por quatro procedimentos antes de ser incorporada ao TPS. Tais procedimentos foram:

1) Palha inteira, apenas lavada (indicado pela letra I na nomenclatura do compósito);

2) Palha moída em moinho de facas da marca Marconi, modelo MA 048 (indicado pela letra $\mathrm{M}$ na nomenclatura do compósito);

3) Palha imersa em água por $24 \mathrm{~h}$, seguido de aquecimento em banho-maria por $2 \mathrm{~h}$ e desfibrilamento (indicado pela letra $\mathrm{C}$ na nomenclatura do compósito);

4) Polpa de palha de arroz obtida por polpação com etanol/água à $180^{\circ} \mathrm{C}$ por 105 minutos (indicado pela letra $P$ na nomenclatura do compósito).

Os teores de palha nos compósitos variaram de 1 a $5 \%$, independente do tratamento. O conteúdo de plasticizante manteve-se fixo em 30\% de glicerol. Para facilitar a leitura, os compósitos obtidos apresentam na nomenclatura o indicativo da quantidade de palha e sua forma de incorporação (exemplo 1: 2l, $2 \%$ de palha incorporada inteira ao TPS; exemplo 2: 4P, $4 \%$ de palha incorporada na forma de polpa ao TPS). Os compósitos que obtiverem $0 \%$ de palha em sua nomenclatura são TPS plasticizados apenas com $30 \%$ de glicerol, sem a incorporação de palha. Estes também podem ser apresentados como TPS amido/glicerol. 


\subsubsection{Absorção de água}

A capacidade de absorção de água para os compósitos amido de arroz/glicerol/palha foi avaliada submetendo as amostras em ambiente de umidade relativa de $53 \%$, com a pesagem até massa constante.

O perfil das curvas obtidas para absorção máxima de água em função do tempo para todos os teores de palha e para todas as formas de incorporação foram similares a apresentada pelo TPS amido/glicerol, apresentando uma rápida absorção de água para tempos menores (até aproximadamente 130h), e absorção mais lenta, tendendo ao equilíbrio para tempos maiores. O equilíbrio de absorção se dá em torno de 240h. Observa-se para amostra sem palha que a absorção é inicialmente mais rápida, mas ao final se torna ligeiramente menor em relação aos compósitos com palha. A presença de palha retardou a absorção de água no começo, mas levou a uma maior absorção em tempos maiores e no equilíbrio.

A figura 4.4.1 ilustra os resultados obtidos para a palha incorporada após imersão em água, aquecimento e desfibrilamento (palha C). A apresentação gráfica apenas para este tipo de palha é exemplo ilustrativo do comportamento geral para todas as amostras.

Figura 4.4.1 - Curvas de absorção de água em função do tempo para amostras de compósitos de palha C condicionadas em ambiente controlado de $53 \%$ u.r.

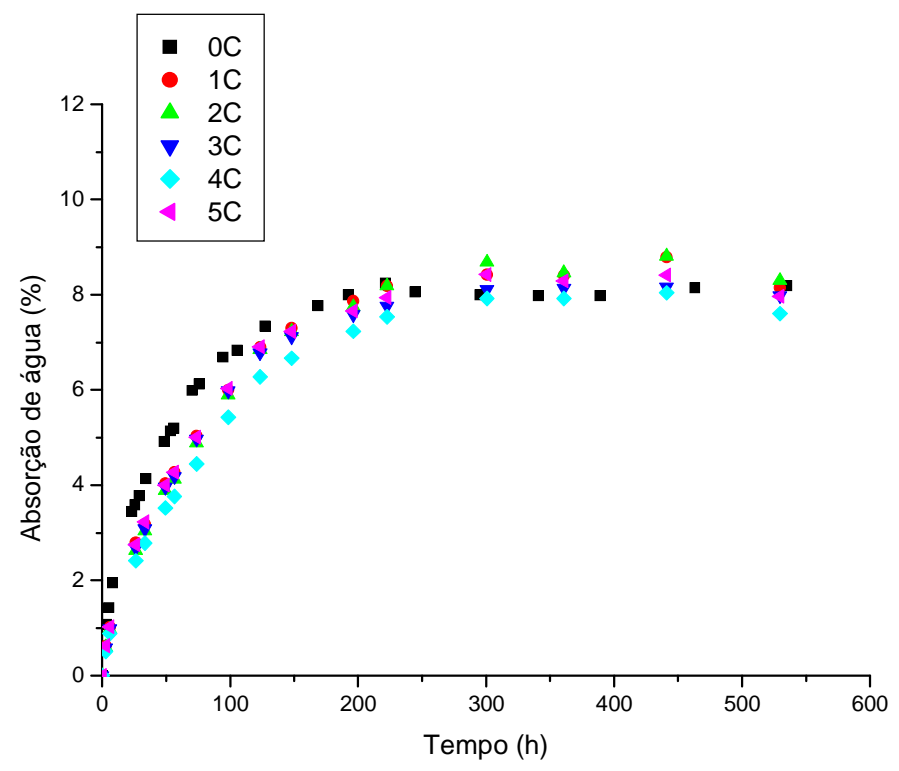


A figura 4.4.2 apresenta os valores de absorção máxima de água para amostras com diversos teores de palha e diversas formas de incorporação desta nos TPS.

Figura 4.4.2 - Absorção máxima de água para os compósitos condicionados em ambiente de u.r. $53 \%$ em função do teor de palha e forma de incorporação.

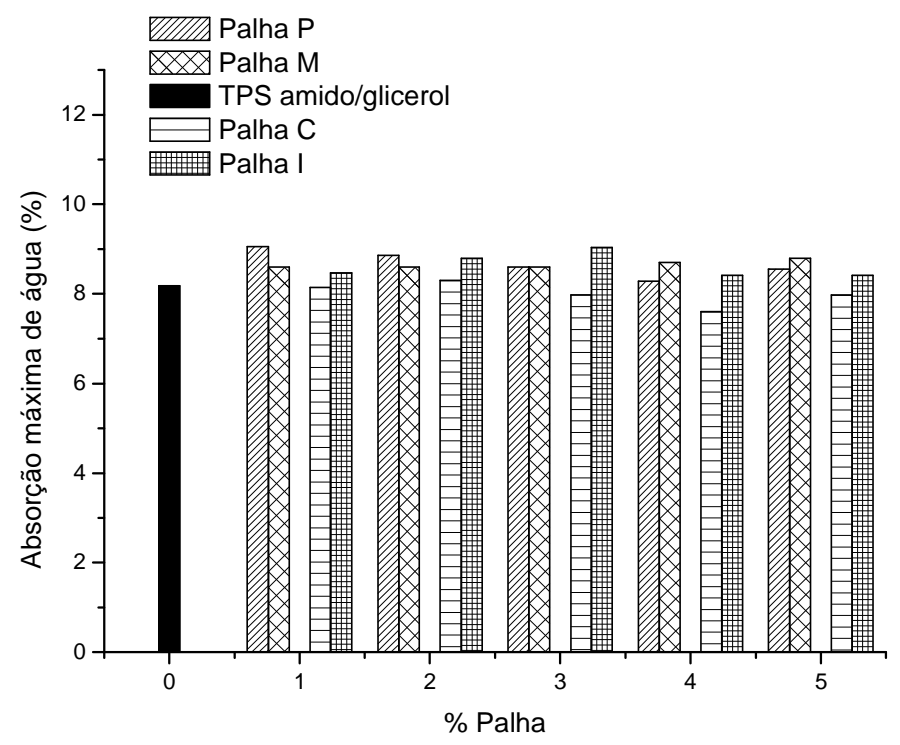

Exceto para amostras com palha $\mathrm{C}$ com teor igual ou maior que $3 \%$, os resultados apresentados na figura 4.4.2 mostram que há um ligeiro aumento da absorção de água com a incorporação de palha aos TPS. Esse aumento não ultrapassa a $10 \%$ e foi independente do conteúdo de palha e sua forma de incorporação.

A literatura tem mostrado que compósitos reforçados com fibra vegetal apresentam tendência a reduzir a capacidade de absorção de água (CURVELO; CARVALHO; AGNELLI, 2001; CARVALHO, 2002; TEIXEIRA, 2007). Essa tendência não foi observada para compósitos reforçados com palha de arroz. Uma possível justificativa é a má dispersão da palha na matriz o que levaria à criação de espaços para acomodar água ou ainda a fraca interação entre palha/matriz, fazendo com que os componentes matriz e palha atuassem de forma isolada na absorção de água. $\mathrm{A}$ palha de arroz em todas as suas formas de incorporação apresenta maior teor de umidade que a matriz TPS amido/glicerol, conforme pode ser visto no item 4.1.4 


\subsubsection{Comportamento mecânico}

Na figura 4.4.3 estão apresentadas as curvas obtidas pelo ensaio mecânico de tração para os compósitos amido de arroz/glicerol/palha.

Figura 4.4.3 - Curvas de tensão x deformação para compósitos amido de arroz/glicerol/palha. (A)

Palha I, (B) Palha C, (C) Palha M e (D) Palha P.
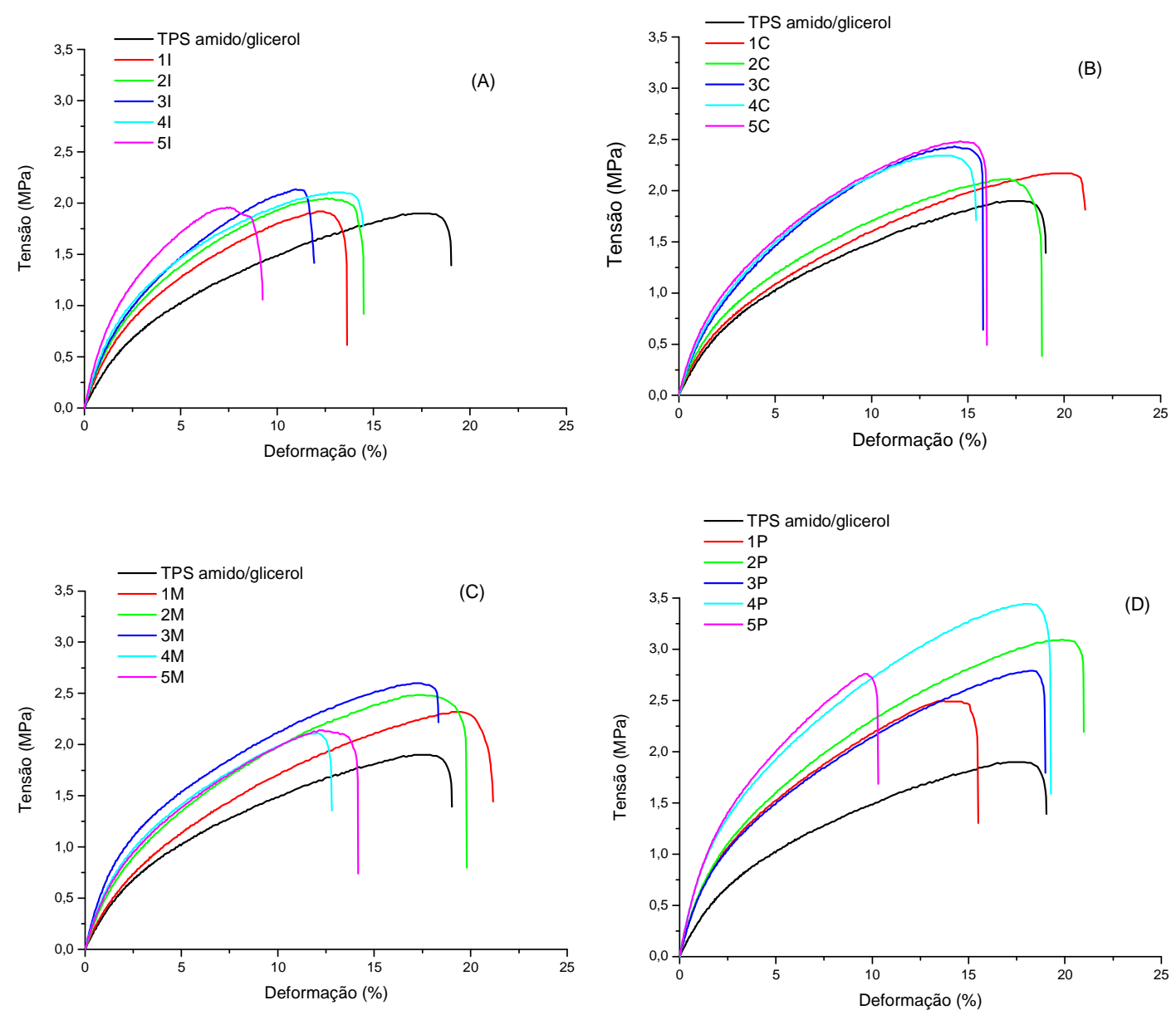

Observa-se que a incorporação de palha não alterou o perfil da curva tensão x deformação do TPS amido/glicerol, sendo que todas as curvas (TPS e compósitos) apresentaram escoamento antes da ruptura do corpo de prova.

A figura 4.4.4 mostra os valores obtidos para tensão máxima, alongamento máximo e módulo elástico. 
Figura 4.4.4 - Tensão máxima (A), alongamento máximo (B) e módulo elástico (C) para compósitos amido de arroz/glicerol/palha.
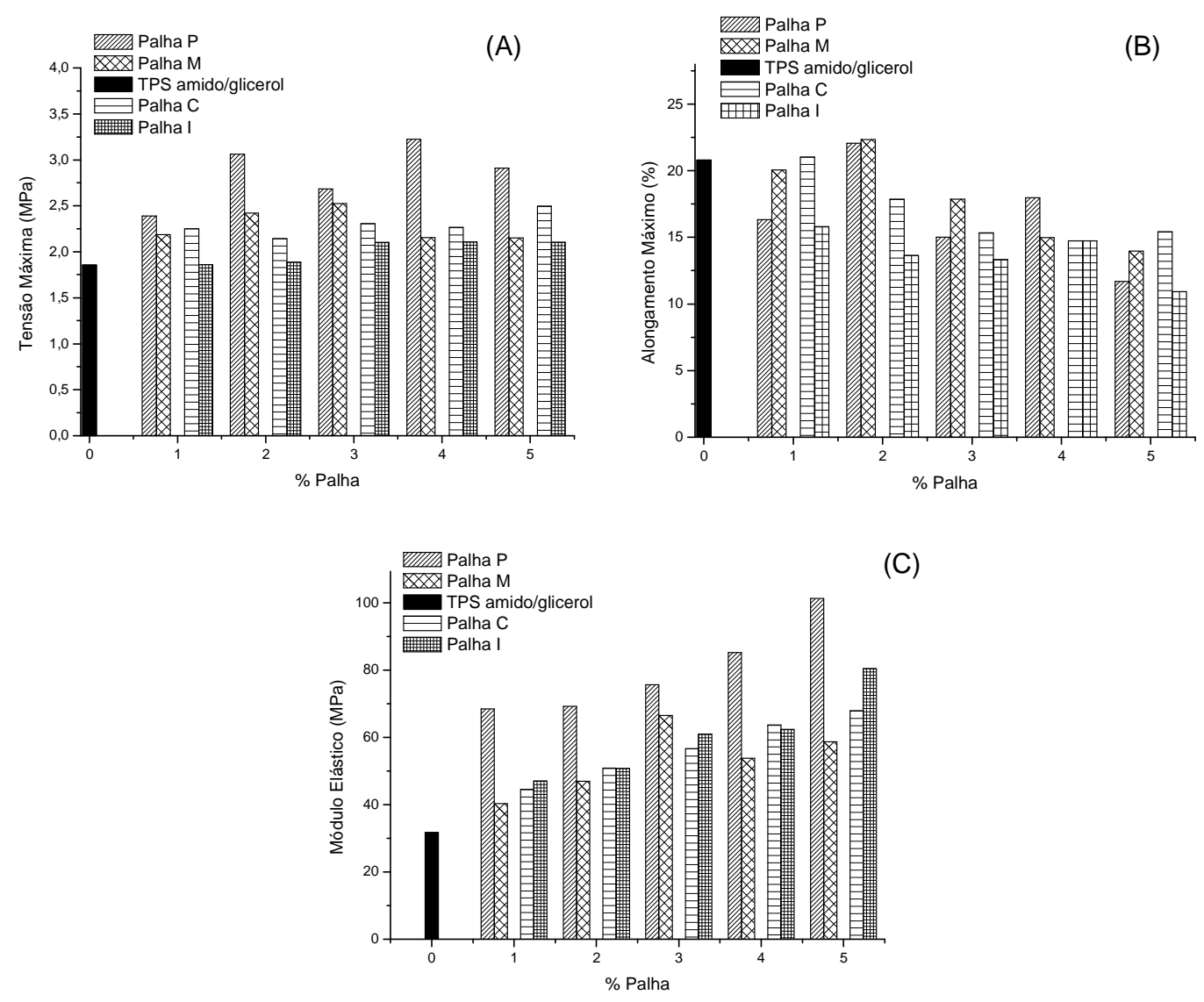

(C)

A incorporação de palha proporcionou um aumento da tensão máxima para todos os tipos de compósito, exceto para aqueles com teores mais baixos de palha I. Este aumento foi mais pronunciado para a palha $\mathrm{P}$ e menos para a palha $\mathrm{I}$. Tal fato pode ser justificado pelo tratamento prévio da palha $\mathrm{P}$ (polpação etanol/água, $180^{\circ} \mathrm{C}$, 105 min.), que favorece a liberação de fibras, responsáveis pelo reforço nestes materiais. $O$ aumento da tensão máxima foi independente da quantidade de palha e chegou até cerca de $73 \%$ para amostras de palha $P$.

Os valores para o módulo elástico também aumentaram com a incorporação de palha. Os compósitos de palha $\mathrm{P}$ foram os que apresentaram maiores valores, obtendo até $218 \%$ de aumento em relação ao TPS amido/glicerol. O acréscimo do módulo elástico foi proporcional ao teor de palha para as palhas $\mathrm{P}, \mathrm{C}$ e I. 
Em relação ao alongamento máximo, houve uma redução nos valores desta propriedade para os compósitos, exceto para amostras com $2 \%$ de palha $\mathrm{P}$ e $\mathrm{M}$. Esta diminuição foi independente da forma de incorporação e teores de palha.

Carvalho (2002), em seu estudo sobre compósitos de amido termoplástico e fibras vegetais, observou resultados similares aos apresentados neste estudo (aumento da tensão máxima e módulo elástico e diminuição do alongamento máximo). (CARVALHO, 2002).

\subsubsection{Cristalinidade e morfologia}

Através da análise da superfície de fratura por MEV pode-se avaliar a dispersão dos reforços utilizados e a adesão entre reforço e matriz.

A figura 4.4.5 apresenta micrografias com aumento de 100X para avaliar a dispersão do reforço na matriz de TPS amido/glicerol. 
Figura 4.4.5 - Micrografias com aumento de 100x para os compósitos com 4\% de palha e aumento de 250x para TPS amido/glicerol.
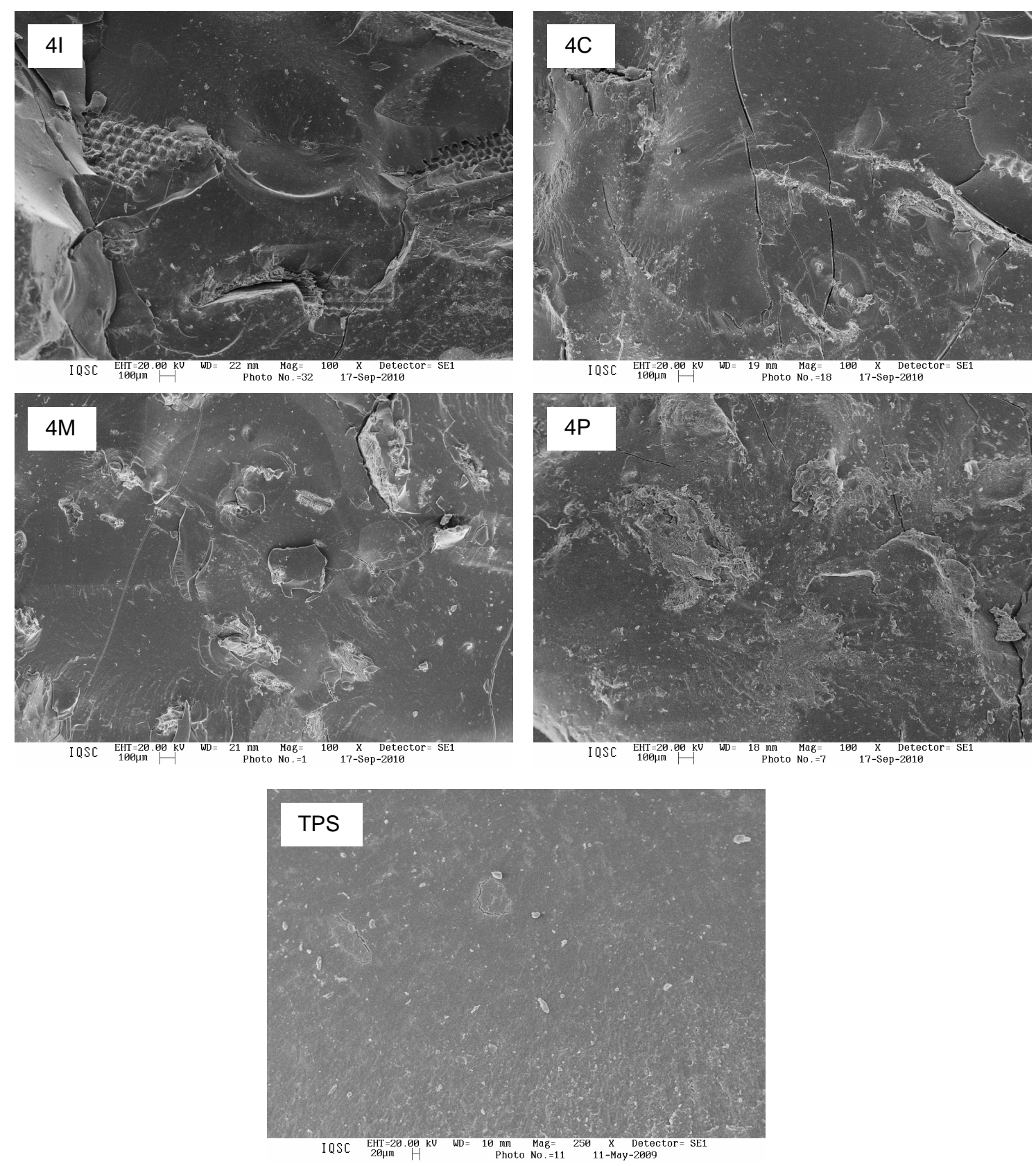

A incorporação de palha proporcionou uma superfície menos homogênea para os compósitos. Para amostras de compósitos reforçados com palhas I, C e M observou-se a presença de grandes pedaços de palha em regiões pontuais dos corpos de prova, sendo que estes pedaços foram menores e a dispersão maior para palha M. A palha $\mathrm{P}$ foi a que apresentou a melhor dispersão, mas ainda assim apresentou regiões de aglomerados de palha. 
Micrografias com aumentos maiores são apresentadas na figura 4.4.6 para avaliação da adesão reforço/matriz.

Figura 4.4.6 - Micrografias de MEV com aumento de 1000x para compósitos com as diversas formas de incorporação de palha.
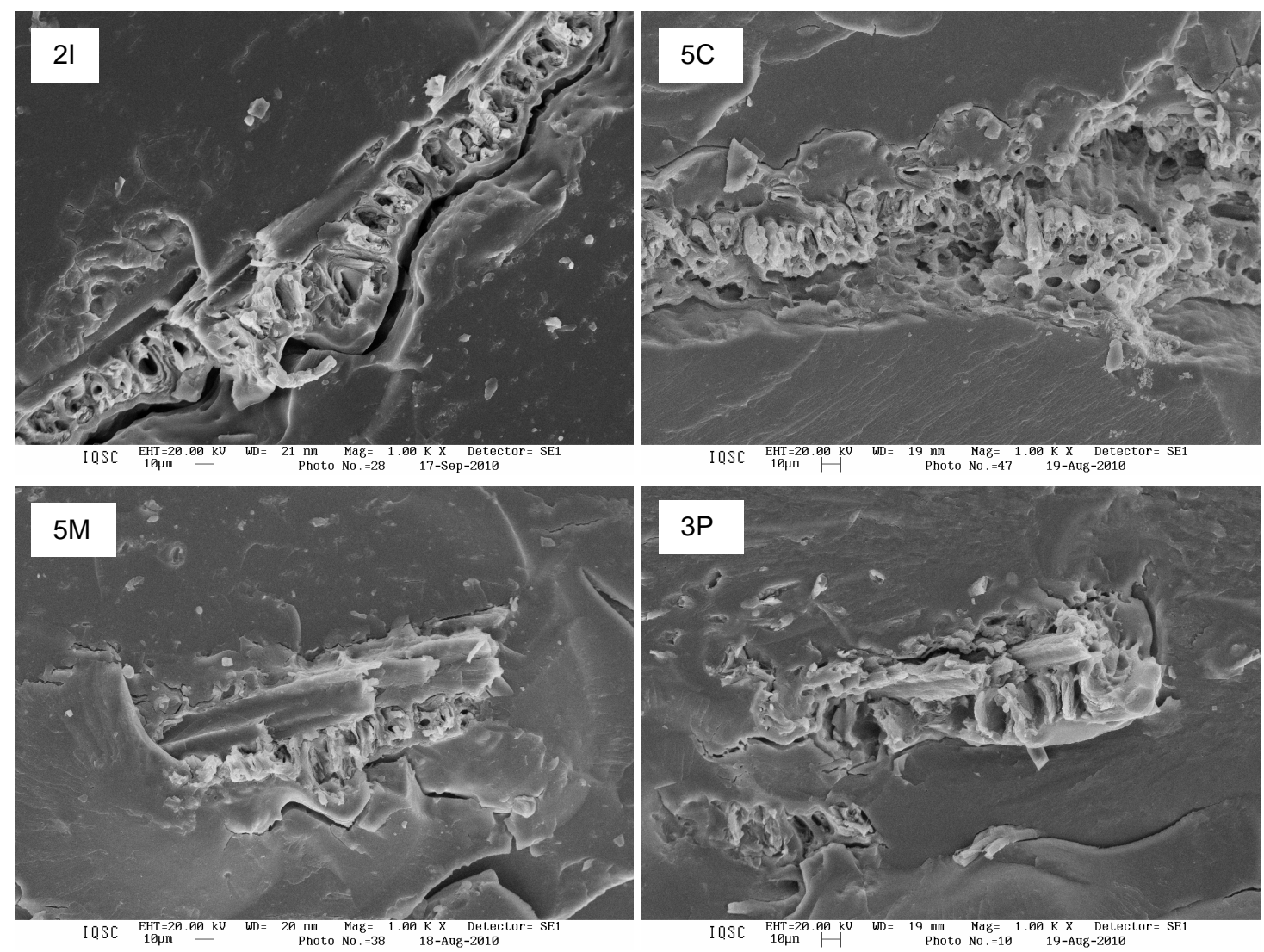

As micrografias com aumentos maiores indicam que não ocorreu pull out, ou seja, remoção das fibras gerando vazios, ou delaminação. De maneira geral, ocorreu a quebra do reforço junto à superfície da matriz sem que ocorresse a remoção deste.

O perfil cristalográfico dos compósitos preparados com polpa P está ilustrado na figura 4.4.7. 
Figura 4.4.7 - Difratogramas de raios-X obtidos para os compósitos com palha $\mathrm{P}$.

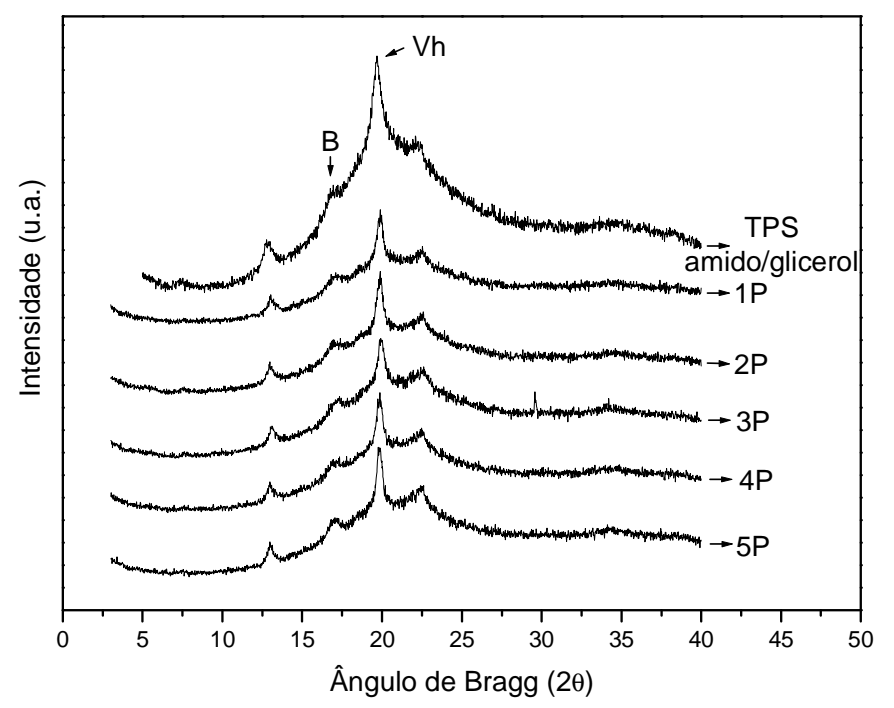

Observa-se o mesmo perfil cristalográfico para todos os compósitos, ou seja, perfil similar ao apresentado pelo TPS amido/glicerol com um pequeno acréscimo na altura do pico entre $2 \theta=22-23$ referente à cristalinidade da celulose contida na palha.

Os valores dos índices de cristalinidade dos tipos B e Vh estão representados na figura 4.4.8. 
Figura 4.4.8 - Índices de cristalinidade do tipo Vh (A) e B (B) para os compósitos amido de arroz/glicerol/palha.
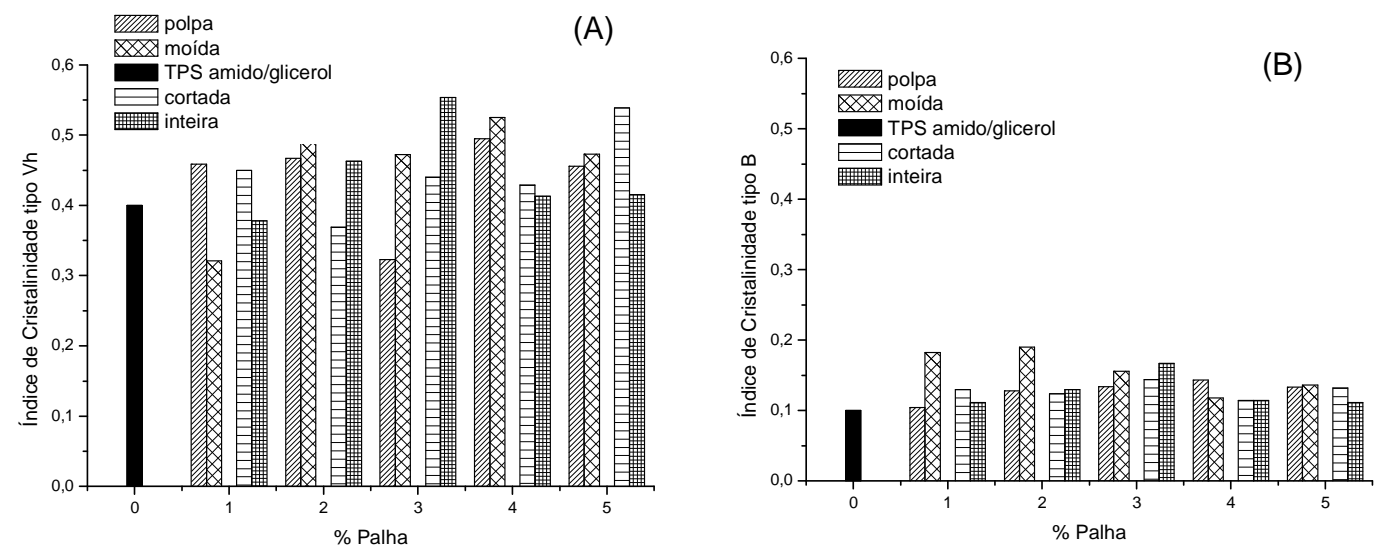

A incorporação de palha a matriz TPS amido/glicerol proporciona um acréscimo de ambos índices de cristalinidade para todos os compósitos, exceto para cristalinidade do tipo Vh das amostras $1 \mathrm{M}, 1 \mathrm{I}, 2 \mathrm{C}$ e 3P. O aumento da cristalinidade é independente do teor e forma de incorporação da palha.

\subsubsection{Caracterização térmica}

A caracterização térmica foi realizada por TG para avaliar a estabilidade térmica dos compósitos e por DMA para a determinação da temperatura de transição vítrea.

A figura 4.4.9 mostra as curvas TG e DTG para os compósitos. 
Figura 4.4.9 - Curvas TG e DTG para compósitos com palha M (A), palha $P(B)$, palha I $(C)$ e palha $C$ (D).
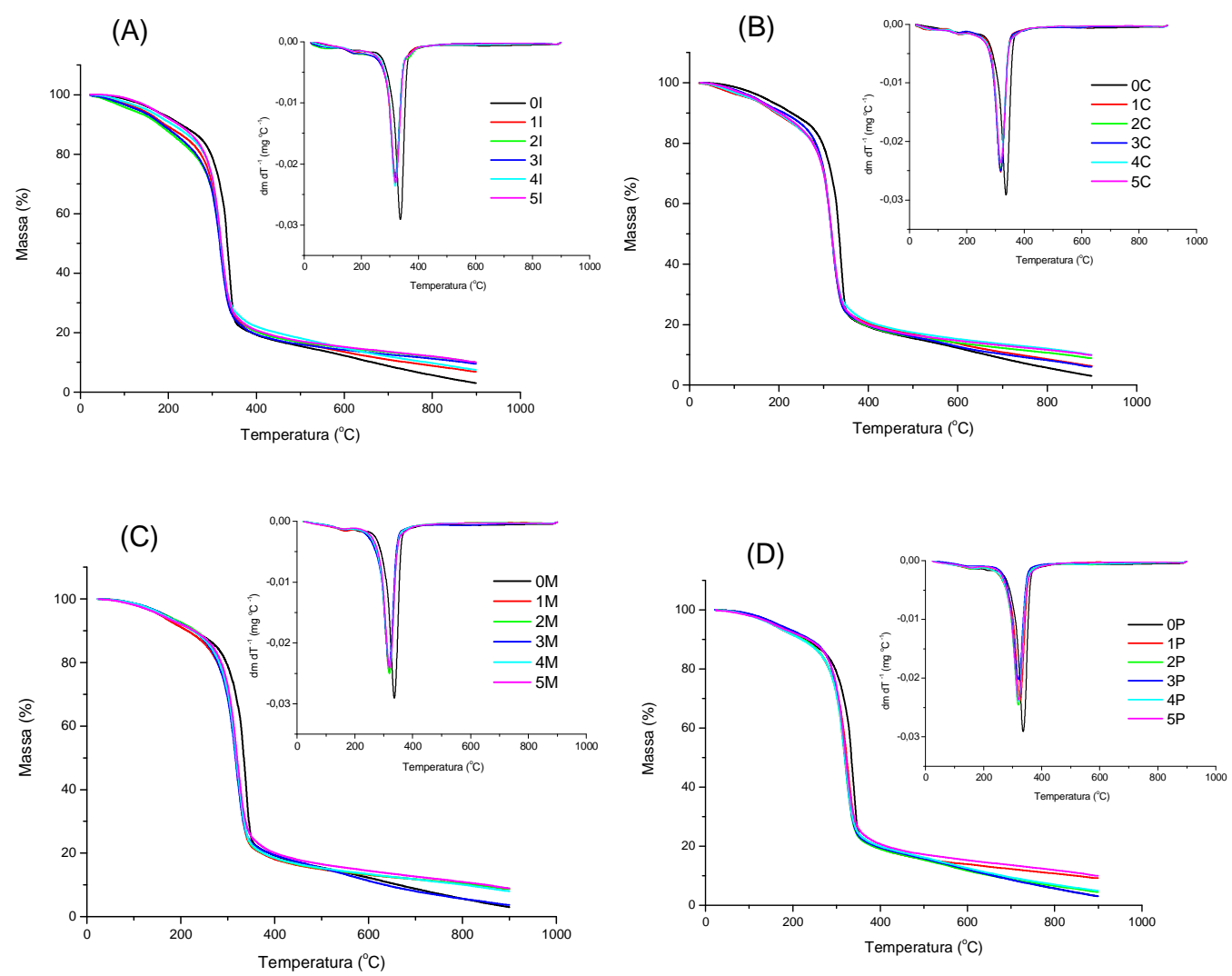

Observa-se que no primeiro evento térmico (da temperatura ambiente até $275^{\circ} \mathrm{C}$ ) há maior perda de massa para os compósitos de palha I e C. Neste evento os compósitos de palha $\mathrm{P}$ e $\mathrm{M}$ apresentam perda de massa mais próxima a do TPS amido/glicerol. Na principal etapa de degradação (de 275 a $400^{\circ} \mathrm{C}$ ) a perda de massa ocorre mais rapidamente para todos os compósitos, sendo que a temperatura de pico para DTG destes está entre 316 e $318^{\circ} \mathrm{C}$, enquanto que para o TPS amido/glicerol está em $336^{\circ} \mathrm{C}$. Acima de $400^{\circ} \mathrm{C}$ nota-se a maior presença de resíduos para o TPS. Estes resíduos, além dos carbonáceos, podem ser oriundos da matéria inorgânica existente na palha de arroz.

O estudo do comportamento térmico por TG mostra que a incorporação de palha exerce alguma influência sobre a estabilidade térmica da matriz amido/glicerol. No entanto, esta influência é independente do teor de palha.

Os resultados obtidos a partir do estudo por DMA para os compósitos com palha I e M estão apresentados na figura 4.4.10. 
Figura 4.4.10 - Tangente de perda (tan $\delta$ ) e módulo de armazenamento (log E’) para compósitos de palha I e palha M.
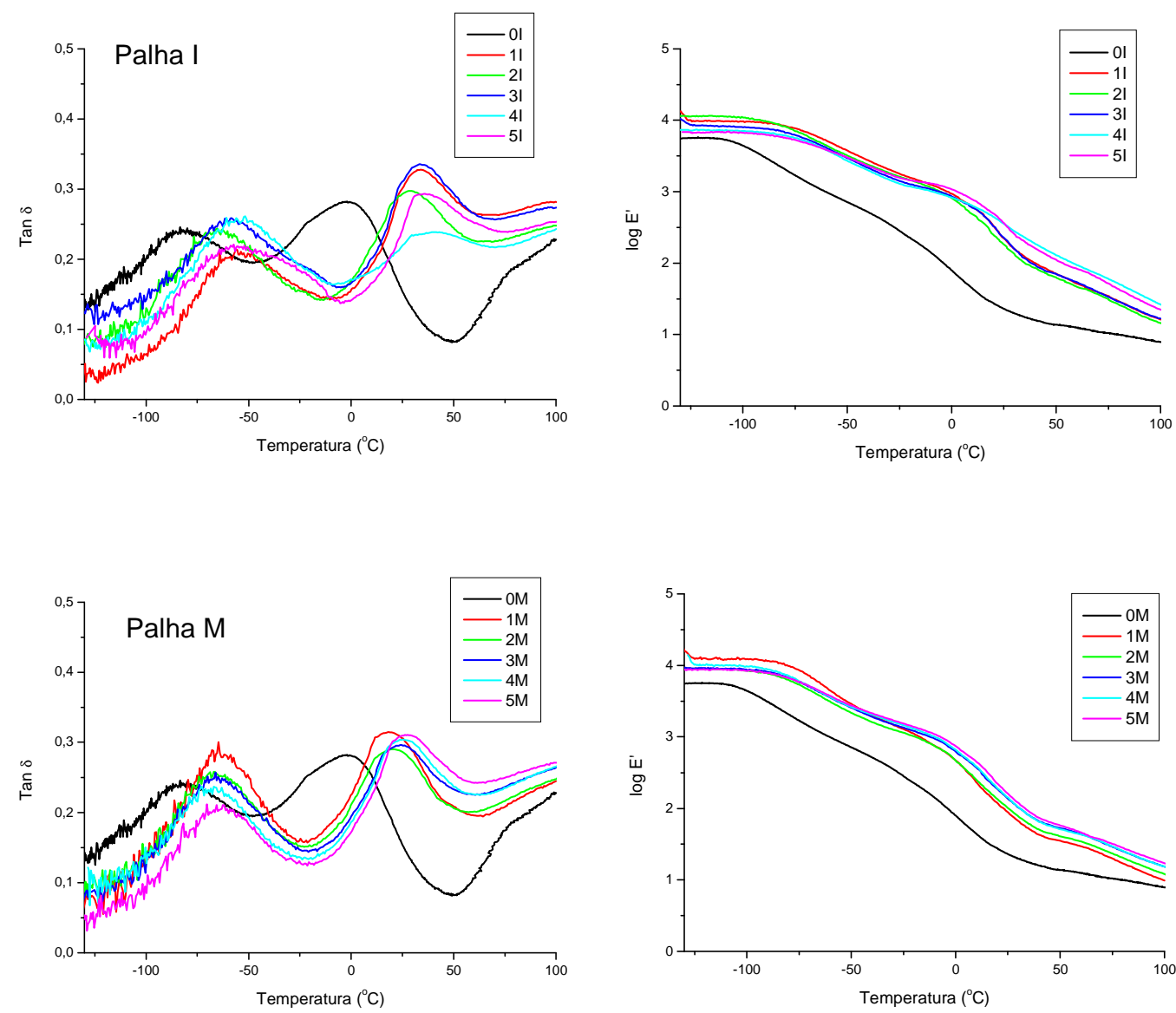

Os compósitos de palha $\mathrm{C}$ e palha $\mathrm{P}$ apresentaram o mesmo perfil de $\tan \delta \mathrm{e}$ módulo de estocagem que as amostras ilustradas na figura 4.4.10.

As curvas de log E' em função da temperatura mostram que o módulo de estocagem de todos os compósitos é maior que o da matriz. Para a palha $\mathrm{M}, \mathrm{o}$ aumento do módulo foi proporcional ao teor de palha, o que não ocorreu para as outras amostras. Os resultados mostram que assim como a matriz, os compósitos também apresentam duas transições, uma relativa à fase rica em glicerol e outra à fase rica em amido. No entanto, essas transições são deslocadas para temperaturas maiores na presença de reforço.

A tabela 4.4.1 apresenta a temperatura de transição vítrea das amostras, considerada como sendo o máximo do pico da transição de maior temperatura. 
Tabela 4.4.1 - Temperatura de transição vítrea para compósitos de palha de arroz.

\begin{tabular}{|c|c|}
\hline Amostra & $\operatorname{Tg}\left({ }^{\circ} \mathrm{C}\right)$ \\
\hline TPS amido/glicerol & 2,0 \\
\hline 11 & 34,0 \\
\hline $2 \mathrm{l}$ & 27,9 \\
\hline 31 & 33,3 \\
\hline 41 & 36,6 \\
\hline 51 & 34,2 \\
\hline $1 \mathrm{C}$ & 23,4 \\
\hline $2 \mathrm{C}$ & 31,0 \\
\hline $3 C$ & 27,4 \\
\hline $4 C$ & 25,4 \\
\hline $5 C$ & 26,0 \\
\hline $1 \mathrm{M}$ & 18,2 \\
\hline $2 \mathrm{M}$ & 20,7 \\
\hline $3 \mathrm{M}$ & 24,7 \\
\hline $4 \mathrm{M}$ & 25,1 \\
\hline $5 \mathrm{M}$ & 27,4 \\
\hline $1 \mathrm{P}$ & 26,1 \\
\hline $2 \mathrm{P}$ & 20,5 \\
\hline $3 P$ & 33,5 \\
\hline $4 \mathrm{P}$ & 41,8 \\
\hline $5 P$ & 22,0 \\
\hline
\end{tabular}


Conforme o esperado, a presença do reforço (palha) confere maior rigidez aos compósitos em comparação com a matriz, o que pode ser evidenciado pelas maiores temperaturas de transição vítrea apresentadas por estes.

\subsubsection{Conclusões parciais}

Conforme esperado, a introdução de palha ao TPS de amido de arroz proporcionou melhor desempenho mecânico. Os valores apresentados para módulo elástico e tensão máxima na ruptura foram maiores para os compósitos do que para os TPS amido/glicerol. Os compósitos preparados com a palha em polpa foram os que apresentaram os melhores resultados, uma vez que foi o tratamento prévio da palha que possibilitou a maior liberação de fibras.

Quanto à capacidade de absorção de água, a presença de palha contribui para o aumento da absorção máxima. Tal aumento não excedeu a 10\%. 


\subsection{Avaliação do comportamento do grão de arroz e quirera na preparação de termoplásticos}

A preparação de termoplásticos diretamente de grãos de arroz ou do subproduto de seu beneficiamento (quirera) poupa a etapa do processo industrial de extração do amido de sua fonte de origem. Tal característica pode ser vantajosa do ponto vista econômico. É com esta motivação que a presente investigação foi conduzida.

Em relação à nomenclatura dos materiais estudados no item 4.5, "TPS quirera", "TPS polido" e "TPS integral" referem-se aos TPS preparados a partir da quirera, do grão de arroz polido e do grão de arroz integral, respectivamente.

\subsubsection{Morfologia e estrutura}

A morfologia dos TPS preparados a partir dos grãos de arroz e quirera está representada na figura 4.5.1. As micrografias mostram que as amostras TPS polido, TPS integral e TPS quirera apresentaram regiões de superfície homogênea, portanto de plasticização eficiente, com regiões de material não desestruturado durante o processamento. 
Figura 4.5.1 - Micrografias de MEV com aumento de 500x para TPS preparados a partir de grãos de arroz, quirera e TPS amido/glicerol.
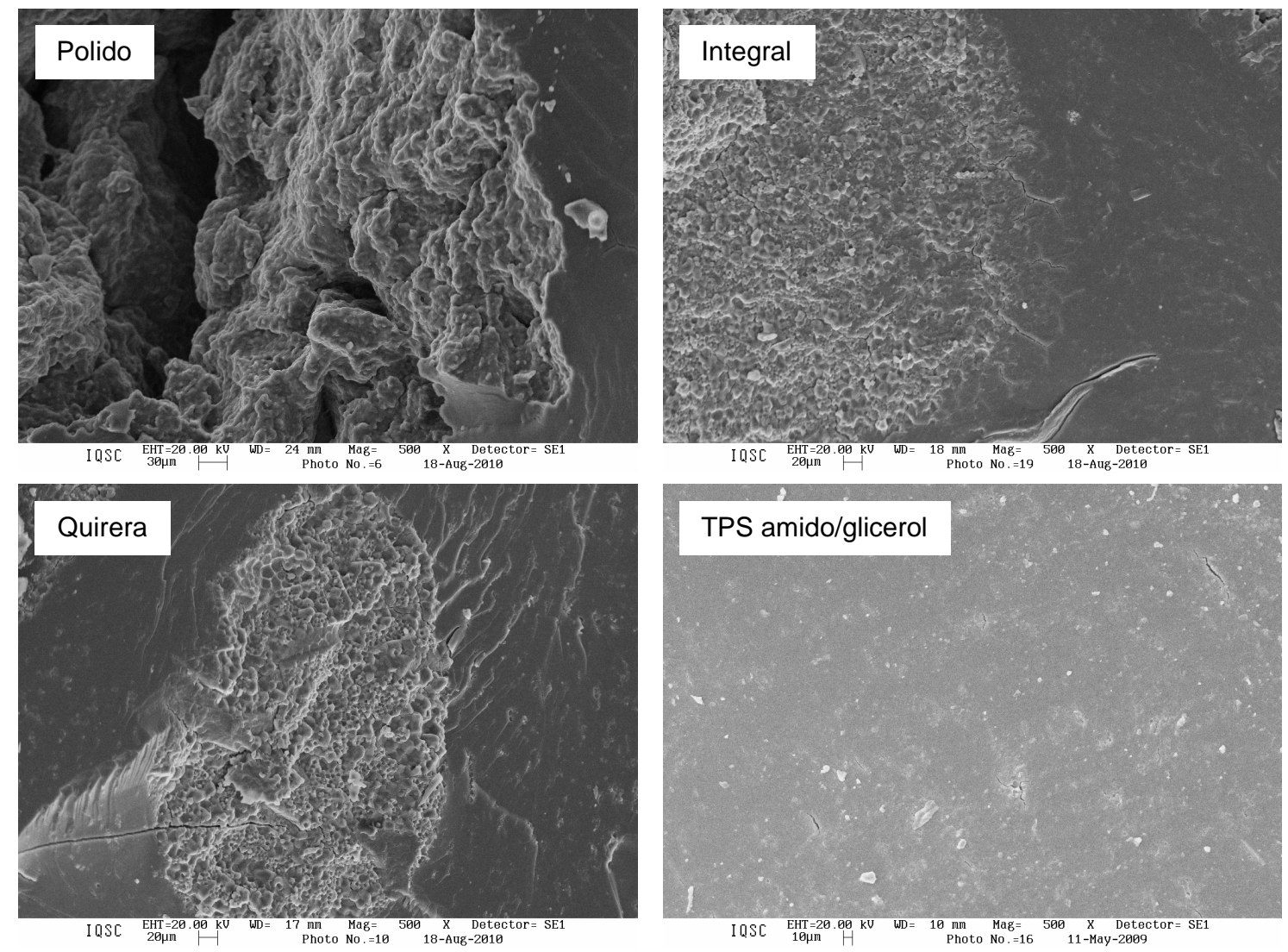

Macroscopicamente os TPS obtidos podem ser visualizados na figura 4.5.2.

Figura 4.5.2 - Foto (A) TPS polido; (B) TPS quirera, (C) TPS integral.

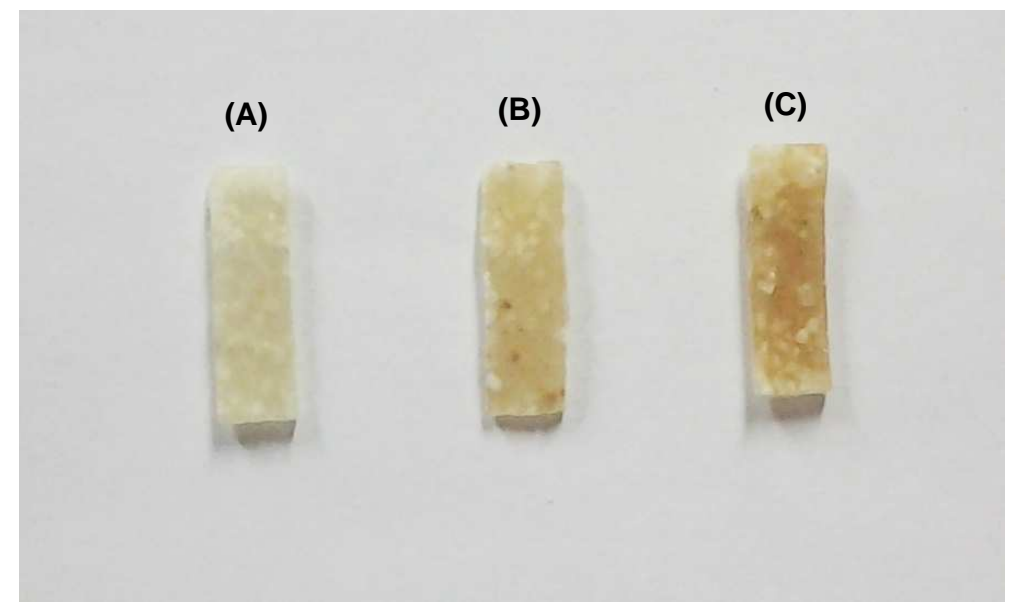

O TPS integral e o TPS quirera apresentaram coloração amarelada/marrom, sendo mais escura para TPS integral. Todos os materiais foram translúcidos, 
entretanto apresentaram pontos brancos indicativos de arroz não desestruturado. A coloração mais escura para o TPS integral e TPS quirera pode estar associada à maior presença de açúcares. Teixeira (2007) observou coloração alaranjada/marrom para TPS preparados a partir de mandioca e glicerol devido aos açúcares presentes na raiz (TEIXEIRA, 2007). O arroz possui pequenas quantidades de açúcares em suas camadas mais externas, sendo estes teores influenciados pelo grau de polimento do grão (WALTER; MARCHEZAN; AVILA, 2008).

O estudo da estrutura por difração de raios-X (difratogramas ilustrados na figura 4.5.3) mostrou que os TPS integral, TPS quirera e TPS polido apresentaram perfil cristalográfico semelhante ao TPS amido/glicerol, com picos em $2 \theta=19,6$ e $2 \theta$ $=12,6$, característicos da cristalinidade do tipo Vh em TPS. Pequenos picos de cristalinidade do tipo B também foram observados.

Figura 4.5.3 - Difratogramas de raios-X dos TPS polido, TPS integral, TPS quirera.

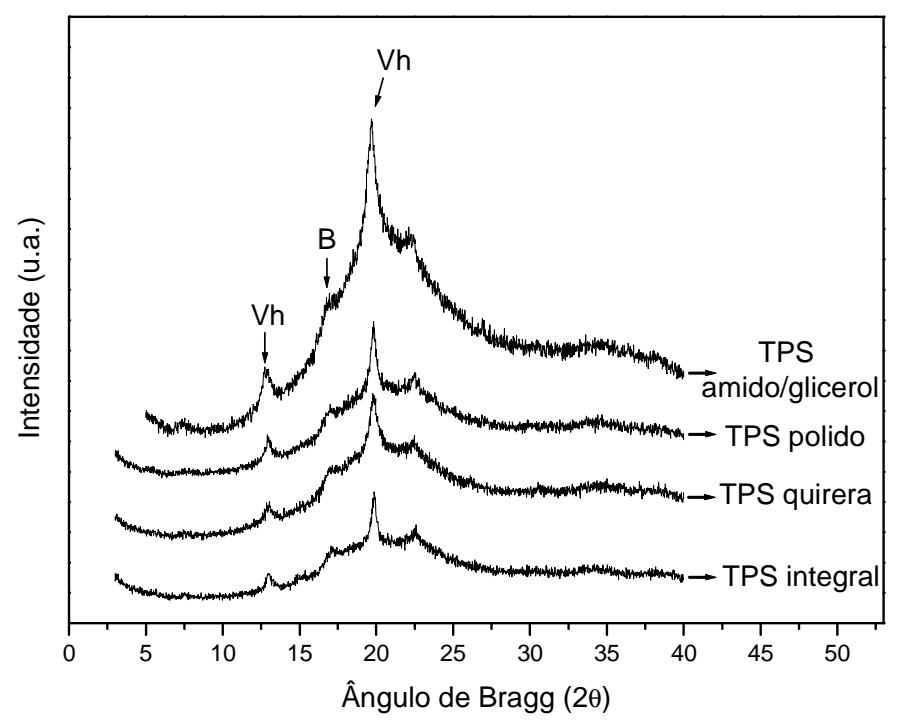

A figura 4.5.4 mostra os índices de cristalinidade do tipo Vh e B para os TPS polido, TPS integral e TPS quirera. 
Figura 4.5.4 - Índices de cristalinidade do tipo Vh (A) e B (B) para amostras TPS quirera, TPS integral e TPS polido.
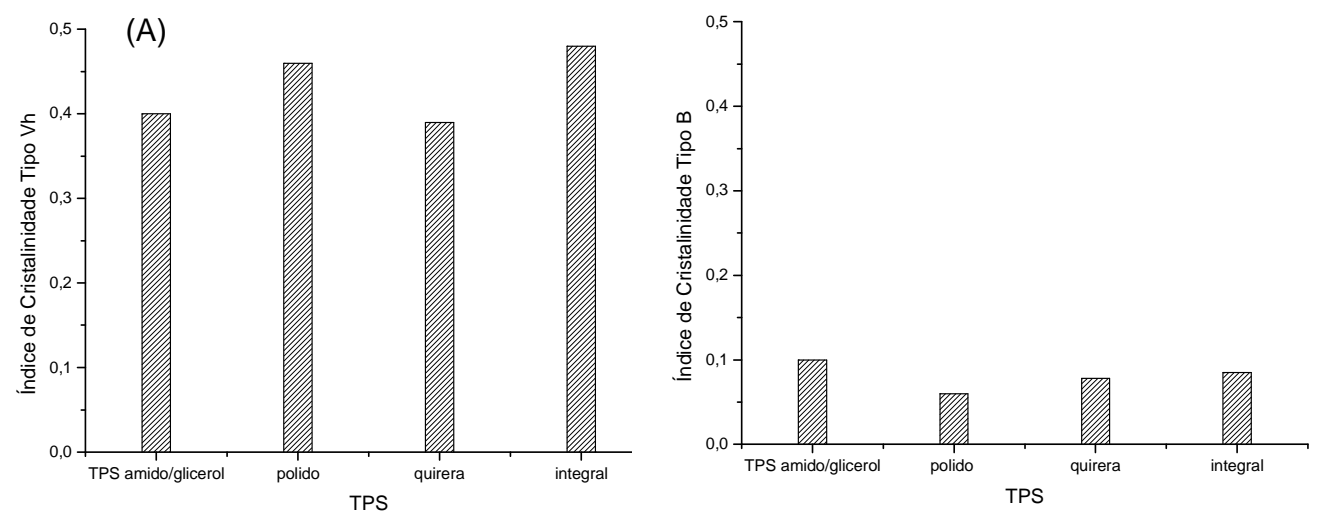

O índice de cristalinidade tipo B é menor para as amostras TPS integral, TPS quirera e TPS polido se comparado com o TPS amido/glicerol. O índice Vh é maior para TPS polido e TPS integral, e menor para TPS quirera. A relação entre os índices de cristalinidade Vh dos TPS polido, TPS integral e TPS quirera está associada ao fato da amilose formar complexos na forma de hélice com lipídeos e proteínas (COLONNA et al., 1987). Assim sendo, como o arroz integral apresenta maiores teores de proteínas e lipídeos, o TPS integral foi o que apresentou maior cristalinidade do tipo Vh.

\subsubsection{Comportamento mecânico e capacidade de absorção de água}

Conforme pode ser visto na figura 4.5.5, as curvas de tensão em função da deformação obtidas para as amostras TPS integral, TPS polido e TPS quirera mostram que, assim como para TPS amido/glicerol, os TPS obtidos a partir dos grãos de arroz e quirera também apresentaram escoamento antes da ruptura. 
Figura 4.5.5 - Curvas de tensão $x$ deformação para TPS integral, TPS quirera e TPS polido.

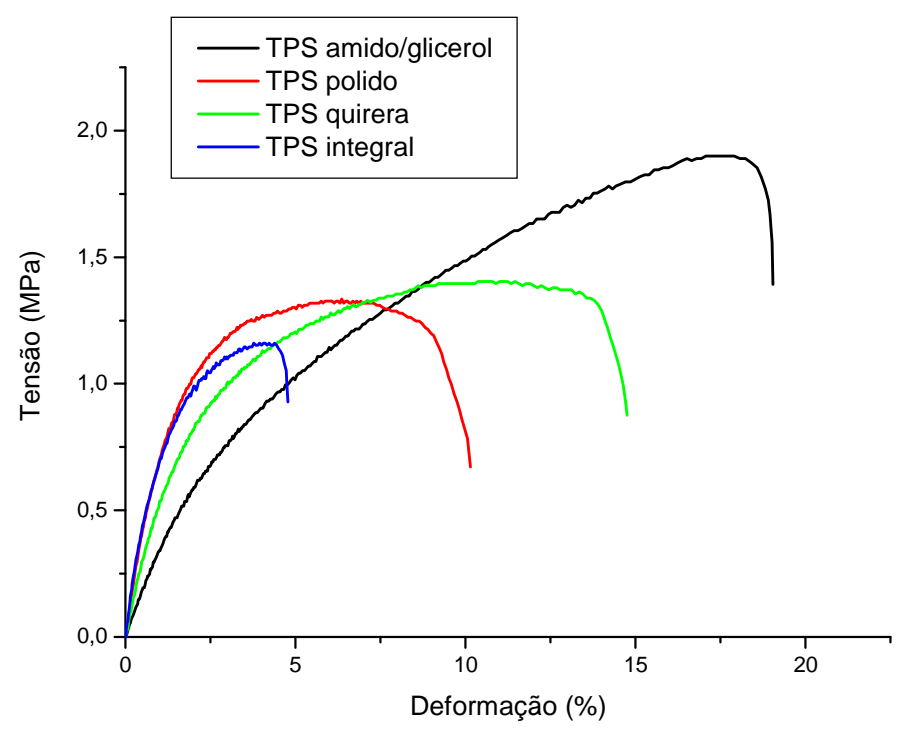

Os valores para tensão máxima, alongamento máximo e módulo elástico estão apresentados na figura 4.5.6. Os valores para tensão máxima foram menores para TPS quirera, TPS polido e TPS integral em relação ao TPS amido/glicerol. Uma possível justificativa para este resultado é o fato dos TPS preparados a partir dos grãos de arroz e quirera apresentarem muitas regiões de material não plasticizado, conforme demonstrado nas figuras 4.5 .1 e 4.5.2, acarretando em TPS menos resistente a tensão. O alongamento máximo obtido para os TPS integral, TPS polido e TPS quirera também foi menor enquanto que o módulo elástico apresentou maiores valores em comparação com o TPS amido/glicerol. Os resultados obtidos para alongamento máximo e para módulo elástico dialogam com os resultados obtidos para o estudo da cristalinidade (item 4.5.1). A literatura relata que maiores valores de módulo elástico e menores valores para alongamento máximo estão associados com maior cristalinidade uma vez que os cristalitos inibem os movimentos entre as cadeias poliméricas (CANEVAROLO, 2002; TEIXEIRA, 2007; CALLISTER, 2008).

Ao comparar-se as amostras TPS quirera, TPS polido e TPS integral entre si, nota-se maiores valores para módulo elástico e menores para alongamento máximo para amostra TPS integral. Uma possível justificativa para tal evidência é o fato do grão de arroz integral apresentar maiores teores de proteínas. Corradini et al. (2006) observaram em todas as composições estudadas que o módulo elástico aumenta, 
enquanto o alongamento diminui com a introdução de proteína zeína aos termoplásticos preparados a partir de amido de milho (CORRADINI et al., 2006).

Figura 4.5.6 - Tensão máxima (A), alongamento máximo (B) e módulo elástico (C) para TPS polido, TPS quirera e TPS integral.
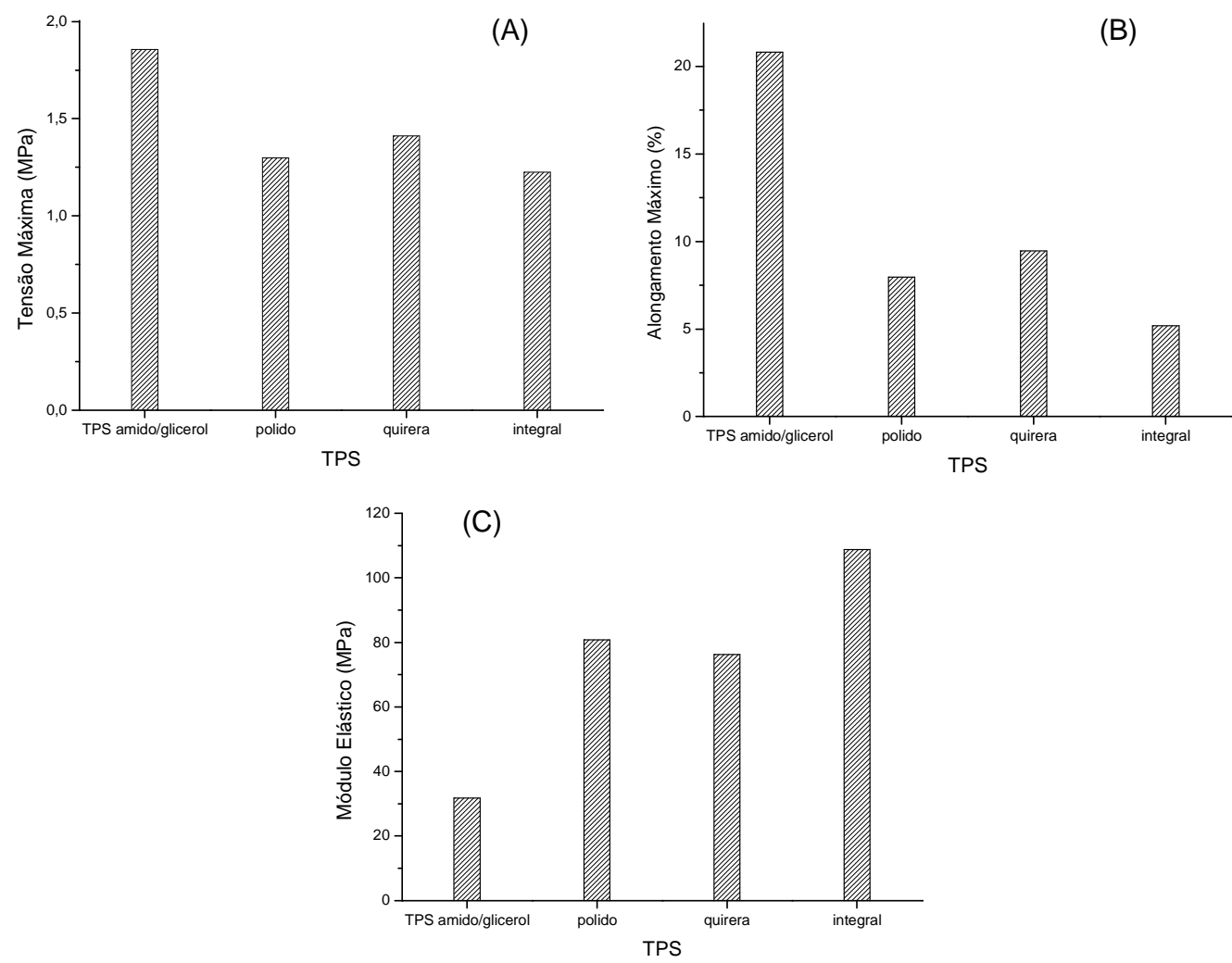

Os resultados obtidos para o estudo da capacidade de absorção de água dos TPS polido, TPS quirera e TPS integral estão representados na figura 4.5.7. Observa-se que a absorção de água dos TPS preparados a partir de grãos de arroz e quirera estabiliza após 300h, ou seja, 12 dias e meio. A absorção máxima de água é maior para os TPS polido, TPS quirera e TPS integral que para o TPS amido/glicerol. Corradini et al. (2006) verificaram que os valores para absorção máxima de água para blendas de TPS com a proteína zeína foram intermediários entre o amido e a zeína (CORRADINI et al., 2006). Os TPS polido, TPS quirera e TPS integral apresentaram absorção máxima de água intermediária entre o amido e os grãos de arroz e quirera puros (ver item 4.1.4 da caracterização dos materiais de partida). 
Figura 4.5.7 - Curvas da absorção de água em função do tempo $(A)$ e absorção máxima de água para TPS integral, TPS quirera e TPS polido condicionados em ambiente de u.r. $=53 \%$.
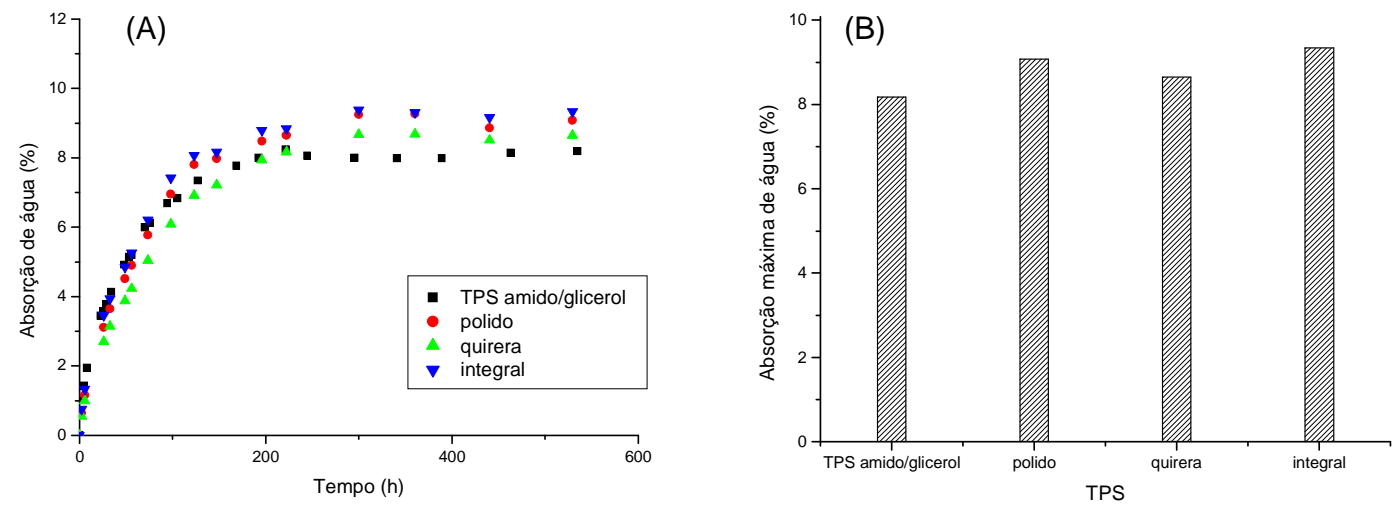

\subsubsection{Caracterização térmica}

A figura 4.5.8 mostra os resultados obtidos para estabilidade térmica a partir da Termogravimetria (TG). Observa-se que os TPS integral, TPS quirera e TPS polido apresentaram curvas de estabilidade térmica ligeiramente diferentes da do TPS amido/glicerol, sendo menos estáveis do ponto de vista térmico. Para a primeira e segunda etapas de perda de massa (primeira refere-se à saída de água e parte do plasticizante e a segunda à degradação do amido) a perda de massa é mais acentuada para os TPS preparados a partir dos grãos de arroz e quirera. A temperatura de pico para a etapa principal de perda de massa é 320,04; 326,62 e $327,92{ }^{\circ} \mathrm{C}$ para os TPS polido, TPS quirera e TPS integral, respectivamente, ao passo que a temperatura de pico para o TPS amido/glicerol está em torno de $336{ }^{\circ} \mathrm{C}$. Acima de $400{ }^{\circ} \mathrm{C}$ até o término do experimento nota-se que há maior presença de resíduos para os TPS quirera e integral. 
Figura 4.5.8 - Curvas TG e DTG para os TPS polido, TPS quirera e TPS integral.

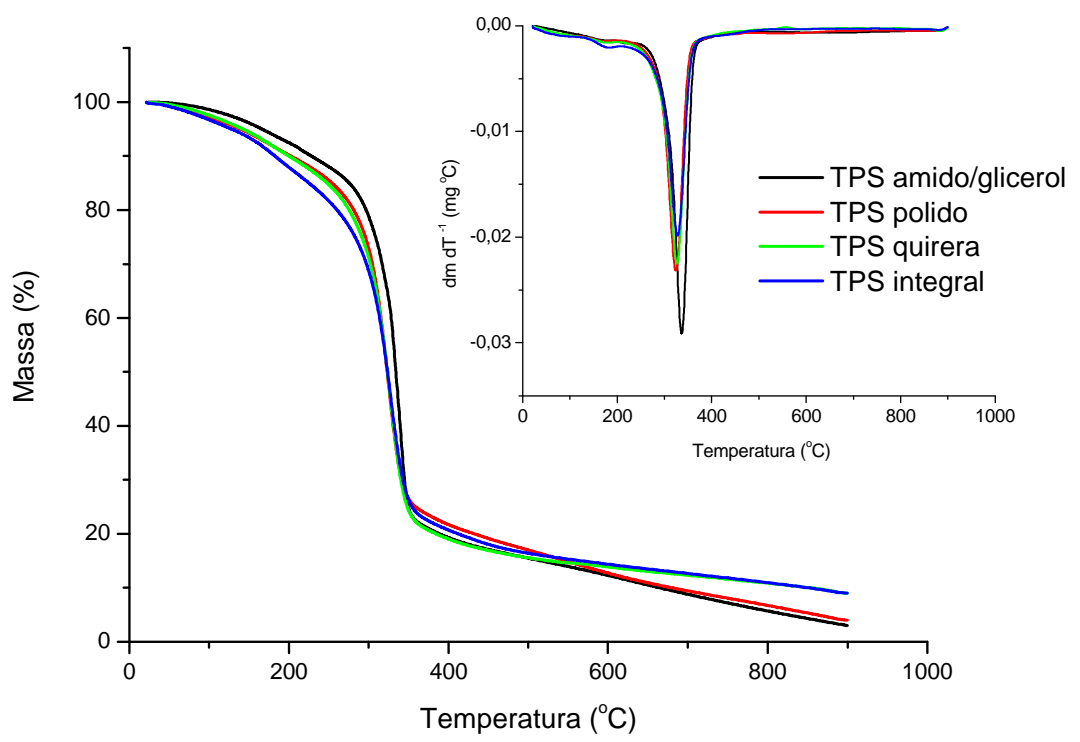

Os resultados obtidos por DMA (apresentados na figura 4.5.9) mostram que, assim como o TPS amido/glicerol, os TPS polido, TPS quirera e TPS integral também apresentaram dois picos de $\tan \delta$, o que significa que eles também possuem duas fases em sua constituição, uma rica em amido e outra rica em glicerol. As Tg dos TPS polido, TPS quirera e TPS integral, representadas pelo máximo do pico de $\tan \delta$, são maiores que a apresentada pelo TPS amido/glicerol. Seus valores são $28,2^{\circ} \mathrm{C} ; 29,1^{\circ} \mathrm{C}$ e $34,1^{\circ} \mathrm{C}$ para os TPS quirera, TPS polido e TPS integral, respectivamente. 
Figura 4.5.9 - Curvas de $\tan \delta(A)$ e log E' (B) em função da temperatura para TPS polido, TPS integral e TPS quirera.
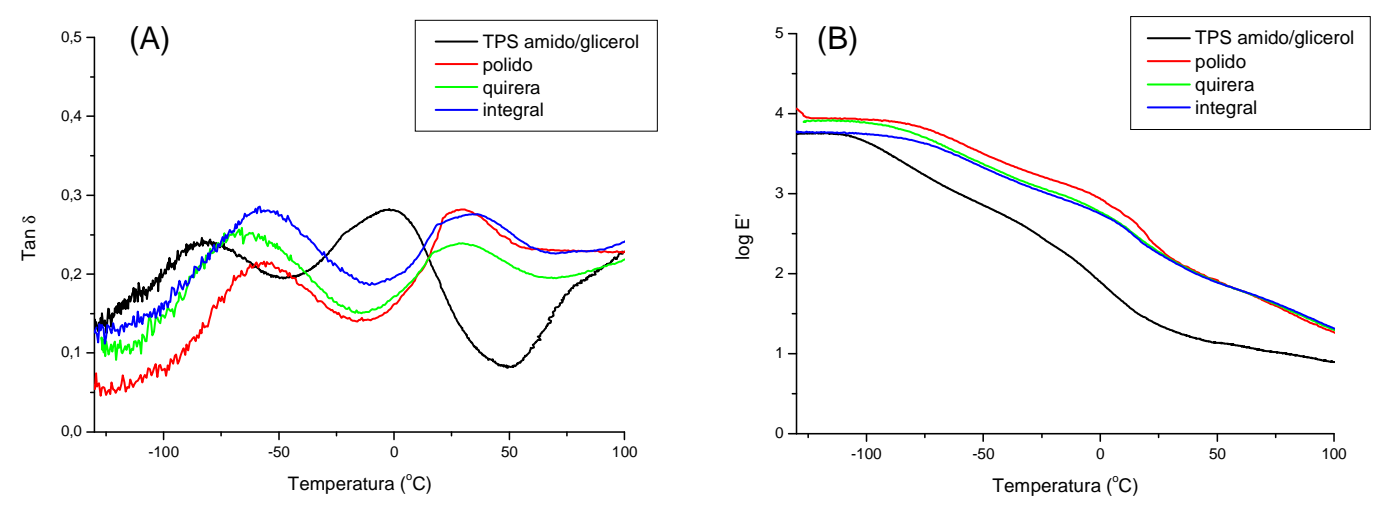

Os resultados obtidos para temperatura de transição vítrea por DMA são condizentes com os resultados obtidos para o estudo da cristalinidade e com os valores alcançados para o módulo elástico. Para ambas propriedades (cristalinidade e módulo elástico) há um aumento em relação ao TPS amido/glicerol e o aumento entre os TPS polido, TPS quirera e TPS integral se dá na mesma direção. Tal observação pode ser justificada pela diferença de teores de proteínas, lipídeos e fibras que há entre os tipos de grãos de arroz (polido e integral) e quirera, o que confere maior cristalinidade para TPS integral e, portanto, maior rigidez, módulo elástico e Tg.

\subsubsection{Conclusões parciais}

A partir do estudo da morfologia e cristalinidade pode-se verificar que o procedimento adotado para o processamento dos termoplásticos proporcionou a plasticização dos grãos de arroz e quirera. Em comparação com o TPS amido/glicerol, os TPS obtidos apresentaram maior cristalinidade, rigidez e temperatura de transição vítrea. No entanto, apresentaram menor estabilidade térmica, menor ductilidade e maior absorção de água.

A forma de processamento do grão de arroz influenciou as propriedades dos TPS. Isso se deu pela diferença de composição entre o grão polido, grão integral e quirera, principalmente em relação aos teores de proteínas, lipídeos e fibras. Contudo, não foi possível distinguir a influência de cada um destes componentes separadamente. 


\section{CONCLUSÕES}

O presente trabalho possibilitou a avaliação da utilização do amido de arroz como composto base para preparação de amidos termoplásticos, fonte esta ainda pouco estudada.

Como um dos objetivos, investigou-se 0 efeito das condições de processamento (tempo e temperatura) na preparação dos amidos termoplásticos. Os resultados apontados nos permitem concluir que a utilização de apenas uma técnica (Reometria de Torque ou Microscopia Eletrônica de Varredura ou Difração de Raios$X)$ é insuficiente para determinação das condições de processamento que melhor contribuem para desestruturação do grânulo, mistura e homogeneização do TPS. As melhores condições indicadas por uma técnica não são necessariamente as mesmas que as indicadas por outras técnicas. Assim, o uso combinado de técnicas é mais apropriado para a escolha das condições de processamento que melhor se adequam a determinada amostra.

Considerando o estudo da composição amido de arroz/glicerol, na qual variou-se o teor de glicerol em 20,25, 30, 35 e 40\%, a alteração das propriedades dos TPS em função do teor de plasticizante seguiu a mesma tendência que os TPS preparados a partir de outras fontes de amido. Com o aumento do teor de glicerol verificou-se o a o aumento da absorção de água, a diminuição da cristalinidade, diminuição dos valores de tensão máxima e módulo elástico. Ao compararmos as propriedades de TPS preparados a partir de amido de mandioca, milho e batata, notou-se que os TPS preparados a partir de amido de arroz apresentaram a menor absorção de água. Em relação a propriedades como índice de cristalinidade tipo Vh, tensão máxima e alongamento máximo, os TPS de amido de arroz apresentaram valores semelhantes aos TPS de amido de mandioca, mas inferiores aos TPS de amido de milho e batata.

Como estratégia para melhorar o desempenho mecânico e reduzir a absorção de água, a incorporação da palha de arroz à matriz termoplástica amido de arroz/glicerol se mostrou eficiente apenas quanto ao primeiro objetivo. A palha foi incorporada após 4 tratamentos prévios: palha inteira, apenas lavada; palha moída; palha imersa em água por $24 \mathrm{~h}$, seguido de aquecimento em banho-maria por $2 \mathrm{~h}$ e desfibrilamento; polpa de palha de arroz obtida por polpação com etanol/água à $180^{\circ} \mathrm{C}$ por 105 minutos. Os teores de palha variaram em 1, 2, 3, 4 e $5 \%$. Todos os 
tratamentos possibilitaram que a palha atuasse enquanto agente de reforço, sendo que a polpa da palha foi a que proporcionou melhores resultados, uma vez que foi o tratamento que possibilitou maior liberação de fibras, que são as responsáveis pelo reforço. O aumento do módulo elástico foi proporcional ao teor de palha. $A$ variação das outras propriedades mecânicas (alongamento e tensão máxima) foi independente da quantidade de palha. Quanto à capacidade de absorção de água, a presença de palha contribuiu para o aumento da absorção máxima. Tal aumento não excedeu a $10 \%$.

Foi possível obter termoplásticos preparados diretamente dos grãos de arroz (polido e integral) e da quirera. Em comparação com o TPS amido/glicerol, os TPS obtidos apresentaram maior cristalinidade, rigidez e temperatura de transição vítrea. No entanto, apresentaram menor estabilidade térmica, menor ductilidade e maior absorção de água. A diferença de composição entre o grão polido, grão integral e quirera, principalmente em relação aos teores de proteínas, lipídeos e fibras influenciou as propriedades dos TPS obtidos. 


\section{REFERÊNCIAS}

AGGARWAL, P.; DOLLIMORE, D. A method of comparison between corn starch and its products using thermal analysis. Instrumentation Science \& Technology, v. 27, p. 191-197, 1999.

AMERICAN SOCIETY FOT TESTING AND MATERIALS. Standart practice for maintaining constant relative humidity by means of aqueous solutions.

Philadelphia, 1985. E104-02.

AMERICAN SOCIETY FOT TESTING AND MATERIALS. Standart test method for tensile properties of plastics. Philadelphia, 1996. D638-96.

AVÉROUS, L. Biodegradable multiphase systems based on plasticized starch: A review. Journal of Macromolecular Science, v. C44, p. 231-274, 2004.

AVÉROUS, L.; BOQUILLON, N. Biocomposites based on plasticized starch: thermal and mechanical behaviors. Carbohydrate Polymers, v. 56, p. 111-122, 2004.

BRETAS, R. E. S.; D'AVILA, M. A. Reologia de polímeros fundidos. São Carlos: Editora UFSCar, 2000. $196 \mathrm{p}$.

BULÉON, A.; COLONNA, P.; PLANCHOT, V.; BALL, S. Starch granules: structure and biosynthesis. International Journal of Biological Macromolecules, v. 23, n. 2, p. 85-112, 1998.

CALLISTER Jr, W. D. Fundamentals of materials science and engineering: an integrated approach. Hoboken, N. J.: John Wiley \& Sons, 2008. 882 p.

CANEVAROLO Jr, S. V. Ciências dos polímeros: um texto básico para tecnólogos e engenheiros. São Paulo: Artliber, 2002. 183 p.

CARVALHO, A. J. F. Compósitos de amido termoplástico e fibras celulósicas: preparação, caracterização e estudo do efeito dos teores de plastificante e reforço. 2002. 166 f. Tese (Doutorado em Ciências e Engenharia de Materiais) Departamento em Ciências e Engenharia de Materiais, Universidade de São Paulo, São Carlos, 2002.

CARVALHO, A. J. F.; CURVELO, A. A.S.; AGNELLI, J. A. M. A first insight on composites of thermoplastic starch and Kaolin. Carbohydrate Polymers, v. 45, p. 189-194, 2001.

CARVALHO, A. J. F.; CURVELO, A. A. S.; AGNELLI, J. A. M. Wood pulp reinforced thermoplastic starch composites. International Journal of Polymeric Materials, v. 51, n. 7, p. 647-660, 2002.

CASTRO, E. M.; VIEIRA, N. R. A.; RABELO, R. R.; SILVA, S. A. Qualidade de grãos em arroz. Santo Antônio de Goiás: Embrapa Arroz e Feijão, 1999. 30 p. (Relatório Técnico)

CEREDA, M. P. Propriedades gerais do amido. São Paulo: Fundação Cargill, 2002. $219 \mathrm{p}$. 
COLONNA, P.; BULEON, A.; MERCIER, C. Physically modified starches. In:

GALLIARD, T. Starch: Properties and potentials. Chichester: John Wiley, 1987. v. 13, p. 79-114.

COMPANHIA NACIONAL DE ABASTECIMENTO. Acompanhamento da safra brasileira: grãos: safra 2010/2011. Brasília: CONAB, 2011. (Relatório Técnico)

CORRADINI, E.; MEDEIROS, E. S.; CARVALHO, A. J. F.; CURVELO, A. A. S.; MATTOSO, L. H. C. Mechanical and morphological characterization of starch/zein blends plasticized with glycerol. Journal of Applied Polymers Science, v. 101, p. 4133-4139, 2006.

CORRADINI, E.; TEIXEIRA, E. M.; AGNELLI, J. A. M; MATTOSO, L. H. C. Amido Termoplástico. São Carlos: Embrapa Instrumentação Agropecuária, 2007. 27 p. (Relatório técnico, documento 30).

COULTATE, T. P. Food - The chemistry of its components. London: Royal Society of Chemistry, 2002. p. 43-45.

CURVELO, A . A; CARVALHO, A . J. F.; AGNELLI J. A .M. Thermoplastic starchcellulosic fibers composites: preliminary results. Carbohydrate Polymers, v. 45, p. 183-188, 2001.

DÁ RÓZ, A. L.; CARVALHO, A. J. F.; GANDINI, A.; CURVELO, A. A. S. The effect of plasticizers on thermoplastic starch compositions obtained by melt processing.

Carbohydrate Polymers, v. 63, p. 417-424, 2006.

DELLA, V. P.; KUNH, I.; HOTZA, D. Caracterização de cinza de casca de arroz para uso como matéria-prima na fabricação de refratários de sílica. Quimica Nova, v. 24, No. 6, p. 778-782, 2001.

FÁVARO, S. L.; LOPES, M. S.; CAMPESE, G.; RADOVANOVIC, E. Preparação de compositos de polietileno pós-consumo com cascas de arroz e estudo de suas propriedades físico-químicas e morfológicas. In: Congresso Brasileiro de Engenharia e Ciência dos Materiais, 2006, Foz do Iguaçu. Anais...2006 p. 4089-4097.

FENGEL, D. E WEGENER, G. Wood: chemistry, ultrastructure and reactions. New York: Walter de Gruyter, 1984. p. 85.

FOLETTO, E. L.; HOFFMANN, R.; HOFFMANN, R. S.; PORTUGAL, U. L.; JAHN, S. L. Aplicabilidade das cinzas da casca de arroz. Quimica Nova, v. 28, No. 6, 10551060, 2005.

FONSECA, J. R.; CUTRIM, V. A.; GUSMÃO, A. R. E.; FARIA, J. M. Descritores Botânicos, Agronômicos e Fenológicos do Arroz. Santo Antônio de Goiás: Empresa Brasileira de Pesquisa Agropecuária, 2008.28 p. (Relatório técnico, documento 226).

FORSSELL, P. M.; MIKKILÃ, J., M.; MOATES,G.K.; PARKER, R. Phase and glass transition behavior of concentrated barley starch-glycerol-water mixtures, a model for thermoplastic starch. Carbohydrate Polymers, v.34, p. 275-282, 1997. 
FORSSELL, P. M.; HULLEMAN, S. H. D.; MYLLÄRINEN, P. J.; MOATE, G. K.; PARKER, R. Ageing of rubbery thermoplastic barley and oat starches. Carbohydrate Polymers, v. 39, p. 43-51, 1999.

GELDERS, G. G.; VANDERSTUKKEN, T.C.; GOESAERT, H.; DELCOUR J. A. Amylose-lipid complexation: a new fractional method. Carbohydrate Polymers, v. 56, p. 447-458, 2004.

GÉRARD, C.; BARRON, C.; COLONNA, P.; PLANCHOT, V. Amylose determination in genetically modified starches. Carbohydrate Polymers, v. 44, p. 19-27, 2001.

GERARDI, V.; MINELLI, F.; VIGGIANO, D. Steam treated Rice industry residues as na alternative feedstock for the wood based particleboard industry in Italy. Biomass. Bioenergy, v. 14, p. 295-299, 1998.

GUINESI, L. S.; DA RÓZ, A. L.; CORRADINI, E.; MATTOSO, L. H. C.; TEIXEIRA, E. M. CURVELO, A. A. S. Kinetics of thermal degradation applied to starches from different botanical origins by non-isothermal procedures. Thermochimica Acta, $v$. 447, p. 190-196, 2006.

HULLEMAN, S. H. D.; KALISVAART, M. G.; JANSSEN, F. H .P.; FEIL, H. VLIEGENTHART, J. F.G. Origins of B-type crystallinity in glycerol-plasticizer, compression-moulded potato starches. Carbohydrate Polymers, v. 39, p. 351-360, 1999.

JAROWENKO, W. Starch based adhesives. In: SKEIST, I. Handbook of Adhesives. 2 ed. New York: Van Nostrand Reinhold Co., 1997. p.192-211.

JAUBERTHIE, R.; RENDELL, F.; TAMBA, S.; CISSE, I. Origin of the pozzolanic effect of rice husks. Construction and Building Materials. v. 14, p. 419-423, 2000.

KIM, H. S.; YANG, H. S.; KIM, K. J.; PARK, H. J. Thermogravimetric analysis of rice husk flour filled thermoplastic polymer composites. Journal of Thermal Analysis and Calorimetry, v. 76, p. 395-404, 2004.

LEIVA, P.; CIANNAMEA, E. M.; RUSECKAITE, R. A.; STEFANI, P. M. Médiumdensity particleboards from rice husks and soybean protein concentrate. Journal of Applied Polymer Science, v. 106, p. 1301-1306, 2007.

LIMBERGER, V. M.; SILVA, L. P.; EMANUELLI, T.; COMARELA, C. G.; PATIAS, L. D. Modificação química e física do amido de quirera de arroz para aproveitamento na indústria de alimentos. Química Nova, v. 31, n. 1, p. 84-88, 2008.

LOURDIN, D.; BIZOT, H. COLONNA P. "Antiplasticization" in starch-glycerol films. Journal of Applied Polymer Science, v. 64, p.1047-1053, 1997.

LUDUEÑA, L.; FASCE, D.; ALVAREZ, V. A.; STEFANI, P.M. Nanocellulose from rice husk following alkaline treatment to remove silica. BioResources, v. 6, p. 14401453, 2011.

MA, X.; YU, J. The effects on plasticizers containing amide groups on the properties of thermoplastic starch. Starch/Stärke, v.56, p. 545-551, 2004a. 
MA, X.; YU, J. Formamide as the plasticizer for thermoplastic starch. Journal of Applied Polymer Science, v. 93, p. 1769-1773, 2004b.

MANSARAY, G.; GHALY, A. E. Thermal degradation of rice husks in nitrogen atmosphere. Bioresources Technology, v. 65, p. 13-20, 1998.

MENDES, Fernanda Miranda. Produção e caracterização de bioplásticos a partir de amido de batata. 2009. 198 f. Dissertação (Mestrado em Físico-Química) Instituto de Química de São Carlos, Universidade de São Paulo, São Carlos, 2009.

MESTRES, C.; MATENCIO, F.; PONS B.; YAJID, M. \& FLIEDEL, G. A rapid method for the determination of amylose content by using differential scanning calorimetry. Starch/Stärke, v. 48, p. 2-6, 1996.

MOATES, G.K.; NOEL, T.R.; PARKER, R.; RING, S.G. Dynamic mechanical and dielectric characterization of amylose-glycerol films. Carbohydrate Polymers, v. 44, p. 247-253, 2001.

MOORTHY, S. N. Physicochemical and functional properties of tropical tuber starches: a review. Starch/Stärke, v. 54, p. 559-592, 2002.

MORAIS, L. C.; CURVELO, A. A. S.; ZAMBON, M. D. Thermoplastic starch Lignosulfonate Blends. 1. Factorial Planning as a tool for elucidating new data from high performance size-exclusion chromatography and mechanical tests.

Carbohydrate Polymer, v. 62, n. 2, p. 104-112, 2005.

NABESHIMA, E. H.; EL-DASH, A. A. Modificação química da farinha de arroz como alternativa para o aproveitamento dos subprodutos do beneficiamento do arroz.

B.CEPPA, Curitiba, v. 22, n. 1, 2004.

PONTES, Bárbara Regina Bouças. Avaliação do amido de batata na preparação de materiais termoplásticos. 2008. Trabalho de conclusão de curso (Graduação em Química) - Instituto de Química de São Carlos, Universidade de São Paulo, São Carlos, 2008.

PRACHAYAWARAKORN, J.; RUTTANABUS, P.; BOONSOM, P. Effect of Cotton Fiber Contents and Lengths on Properties of Thermoplastic Starch Composites Prepared from Rice and Waxy Rice Starches. J Polym Environ, v.19, p. 274-282, 2011.

PRACHAYAWARAKORN, J.; SANGNITIDEJ, P.; BOONPASITH, P. Properties of thermoplastic rice starch composites reinforced by cotton fiber or low-density polyethylene. Carbohydrate Polymers, v. 81, p. 425-433, 2010.

PUSHPADASSA, H. A.; MARX, D. B.; HANNA, N. A. Effects of Extrusion Temperature and Plasticizers on the Physical and Functional Properties of Starch Films. Starch/Stärke, v. 60, p. 527-53, 2008.

RAMEZANIANPOUR, A. A.; KHANI, M. M.; AHMADIBENI, G. The Effect of Rice Husk Ash on Mechanical Properties and Durability of Sustainable Concretes. International Journal of Civil Engineerng, v. 7, No. 2, p. 83-91, 2009. 
SILVA, Paulo Jorge da Silva. Estudo cinético da deslignificação etanol-água da casca de arroz. Derivatização da casca e da polpa celulósica. 1997. 107 f. Tese (Doutorado em Físico-Química) - Instituto de Química de São Carlos, Universidade de São Paulo, São Carlos, 1997.

STEFANI, P. M.; GARCIA, D.; LOPEZ, J.; JIMENEZ, A. Thermogravimetric analysis of composites obtained from sintering of rice husk-scrap tire mixtures. Journal of Thermal Analysis and Calorimetry, v. 81, p. 315-320, 2005.

TAKAGI, H.; ICHIHARA, Y. Effect of fiber length on mechanical properties of "green" composites using a starch-based resin and short bamboo fibers. JSME International Journal - Séries A, v. 47, p. 551-555, 2004.

TEIXEIRA et al., 2005;TEIXEIRA, E. M.; DA RÓZ, A. L.; CARVALHO, A. J. F.; CURVELO, A. A. S. Preparation and characterisation of thermoplastic starches from cassava starch, cassava root and cassava bagasse. Macromolecules, v. 29, p. 266275, 2005.

TEIXEIRA, Eliangela de Moraes. Utilização de amido de mandioca na preparação de novos materiais termoplásticos. 2007. 201 f. Tese (Doutorado em Química) Departamento em Físico-Química, Universidade de São Paulo, São Carlos, 2007.

TESTE, F. R; KARKALAS, J.; Qi, X. Starch-composition, fine structure and architecture. Journal of Cereal Science, v. 39, p. 151-161, 2004.

VAN DER BURGT, Y. E. M.; BERGSMA, J.; BLEKEER, I. P.; MIJLAND, P. J. H. C.; KAMERLING, J. P.; VLIEGENHART, J. F. G. Structural studies on methylatedstarch granules. Starch/ Stärke, v. 52, n. 2-3, p. 40-43, 2000.

VAN SOEST, J. J. G.; HULLEMAN, S. H. D.; WIT, D. de; VLIEGENTHAR, J. F. G. Crystallinity in starch bioplastics. Industrial Crops and Products, v. 5, p. 11-22, 1996.

VAN SOEST J., J., G.; VLIEGENTHART J. F. G. Crystallinity in starch plastics: consequences for material properties. Trends in Biotechnology, v.15, p. 208-213, 1997.

YU, L.; DEAN, K.; LI, L. Polymers blends and composites from renewable resources.

Progress in Polymer Science, v. 31, p. 576-602, 2006. 